\title{
WestVirginiaUniversity
}

THE RESEARCH REPOSITORY @ WVU

Graduate Theses, Dissertations, and Problem Reports

2000

\section{Food habits of the Allegheny woodrat (Neotoma magister )}

Nikole Lee Castleberry

West Virginia University

Follow this and additional works at: https://researchrepository.wvu.edu/etd

\section{Recommended Citation}

Castleberry, Nikole Lee, "Food habits of the Allegheny woodrat (Neotoma magister )" (2000). Graduate Theses, Dissertations, and Problem Reports. 1105.

https://researchrepository.wvu.edu/etd/1105

This Thesis is protected by copyright and/or related rights. It has been brought to you by the The Research Repository @ WVU with permission from the rights-holder(s). You are free to use this Thesis in any way that is permitted by the copyright and related rights legislation that applies to your use. For other uses you must obtain permission from the rights-holder(s) directly, unless additional rights are indicated by a Creative Commons license in the record and/ or on the work itself. This Thesis has been accepted for inclusion in WVU Graduate Theses, Dissertations, and Problem Reports collection by an authorized administrator of The Research Repository @ WVU. For more information, please contact researchrepository@mail.wvu.edu. 
Food Habits of the Allegheny Woodrat (Neotoma magister)

by

Nikole Lee Castleberry

\author{
A Thesis \\ Submitted to the Graduate Faculty of \\ at West Virginia University \\ In partial fulfillment of \\ Requirements for the Degree \\ MASTER OF SCIENCE \\ in Wildlife and Fisheries Resources \\ Division of Forestry \\ Petra Bohall Wood, Ph.D., Chair \\ W. Mark Ford, Ph.D. \\ John W. Edwards, Ph.D. \\ Michael T. Mengak, Ph.D.
}

The College of Agriculture, Forestry, and Consumer Sciences

\title{
MORGANTOWN, WV
}

2000

Keywords: Allegheny woodrat, central Appalachians, food habits, microhistology, Neotoma magister,
timber management.

Copyright 2000 Nikole L. Castleberry 


\title{
ABSTRACT \\ FOOD HABITS OF THE ALLEGHENY WOODRAT (Neotoma magister)
}

\author{
Nikole L. Castleberry
}

Regional declines in Allegheny woodrat (Neotoma magister) populations suggest a better understanding of the ecology of this species is needed for proper management. I described seasonal food habits of the Allegheny woodrat in the Ridge and Valley and Allegheny Plateau physiographic provinces of West Virginia and Virginia using microhistological techniques. In the Allegheny Plateau, the top 5 food items were fungi, blueberries (Vaccinium spp.), acorns (Quercus spp.), ferns (Dryopteris spp.), and lichens. In the Ridge and Valley woodrats ate primarily blackberry (Rubus spp.) leaves, fungi, greenbrier (Smilax spp.) leaves, acorns, and oak leaves. Additionally, we examined the effects of common timber management practices such as clearcuts and diameter-limit harvests, on Allegheny woodrat food habits in the Allegheny Plateau. We saw no significant differences in use between treatment types. Additionally, there were no differences in richness or diversity measures between harvest types, although all values were higher at undisturbed sites than either harvest treatment. 


\section{DEDICATION}

In loving memory of Judith Lee Lyon-Swasey. 


\section{ACKNOWLEDGMENTS}

Primary funding for this study was provided by the Westvaco Corporation, additional funding was provided by the West Virginia Cooperative Fish and Wildlife Research Unit, USGS-BRD. I also thank West Virginia University Division of Forestry.

I give thanks to Dr. Petra B. Wood for serving as my major professor. I am particularly grateful to Dr. W. Mark Ford for his support, encouragement, and friendship over the past 3 years, without which this would not have been possible. I also thank Dr. John W. Edwards and Dr. Michael T. Mengak for their assistance while serving on my committee. Dr. W. Mark Ford and Steven B. Castleberry were instrumental in acquiring funding for this study and provided valuable guidance. Dr. William V. Thayne provided assistance with statistical analysis.

I thank those individuals who provided field assistance, including Eric Moore, Courtney Hillpot, Rusty Caton, Karen Logwood, Deanna Carlson, and Joey Hinton. I give special thanks to Jane Rodrigue, Chris Dobony, Alex Menzel, Jennifer Menzel, Brian Smith, and Rebecca Smith for their assistance and friendship.

I wish to thank my family, especially my husband and parents, for their love, support, and encouragement throughout my college career. Without their support, this would not have been possible. 


\section{TABLE OF CONTENTS}

ACKNOWLEDGMENTS $\ldots \ldots \ldots \ldots \ldots \ldots \ldots \ldots \ldots \ldots \ldots \ldots \ldots \ldots \ldots \ldots \ldots$

LIST OF TABLES $\ldots \ldots \ldots \ldots \ldots \ldots \ldots \ldots \ldots \ldots \ldots \ldots \ldots \ldots \ldots \ldots$

LIST OF FIGURES $\ldots \ldots \ldots \ldots \ldots \ldots \ldots \ldots \ldots \ldots \ldots \ldots \ldots \ldots \ldots \ldots \ldots$

CHAPTER 1. INTRODUCTION AND LITERATURE REVIEW $\ldots \ldots \ldots \ldots \ldots \ldots 1$

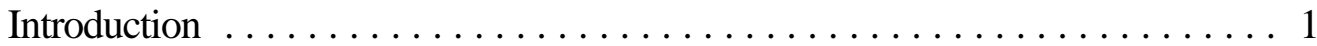

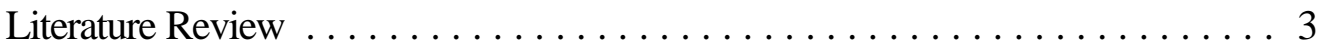

Description of Study Area $\ldots \ldots \ldots \ldots \ldots \ldots \ldots \ldots \ldots \ldots \ldots \ldots \ldots \ldots \ldots \ldots$

Literature Cited . . . . . . . . . . . . . . . . . . . . 10

CHAPTER 2. FOOD HABITS OF THE ALLEGHENY WOODRAT IN THE CENTRAL APPALACHIANS OF WEST VIRGINIA AND VIRGINIA . . . . . . . . . . 20

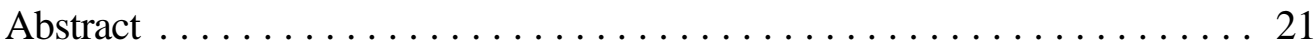

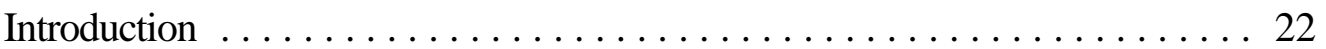

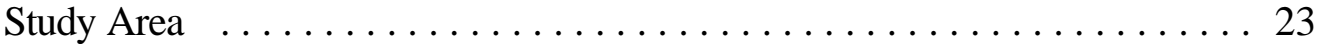

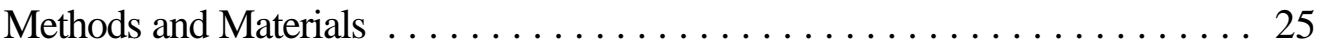

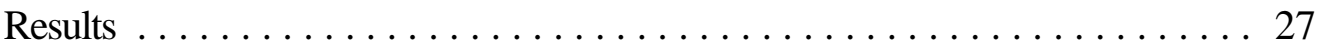

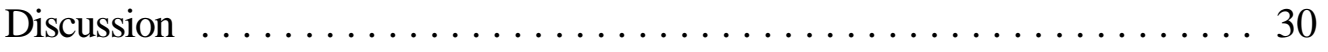

Management Implications $\ldots \ldots \ldots \ldots \ldots \ldots \ldots \ldots \ldots$

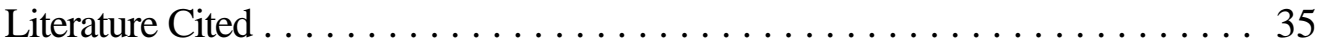

CHAPTER 3. THE EFFECTS OF FOREST MANAGEMENT ON THE FOOD HABITS OF THE ALLEGHENY WOODRAT IN WEST VIRGINIA $\ldots \ldots \ldots \ldots \ldots \ldots \ldots \ldots$

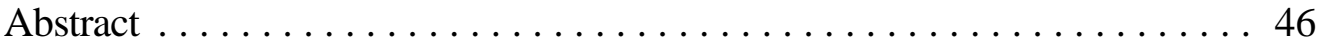

Introduction $\ldots \ldots \ldots \ldots \ldots \ldots \ldots \ldots \ldots \ldots \ldots \ldots \ldots \ldots \ldots \ldots \ldots \ldots \ldots$

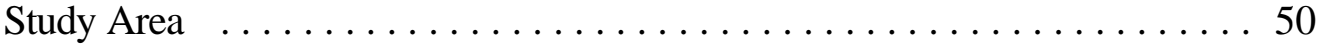

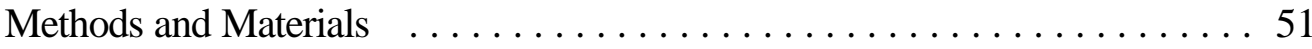




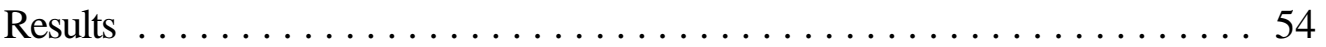

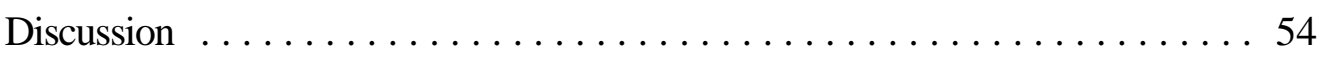

Magement Implications $\ldots \ldots \ldots \ldots \ldots \ldots \ldots \ldots \ldots \ldots \ldots \ldots$

Literature Cited ............................. 60

APPENDIX A. Reference material used to aid in plant cell identification ......... 72

APPENDIX B. Food items that composed $>2 \%$ of the total diet of Allegheny woodrats in any season from November 1997-December 1998 in the Ridge and Valley and Allegheny Plateau physiographic

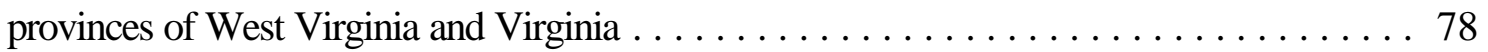

APPENDIX C. Food items that composed $>2 \%$ of the total diet of male and female Allegheny woodrats in any season from November 1997-December 1998 in the Ridge and Valley physiographic

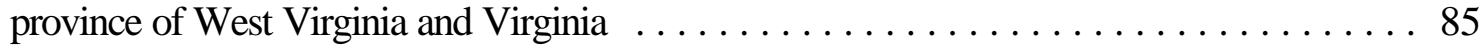

APPENDIX D. Food items that composed $>2 \%$ of the total diet of male and female Allegheny woodrats in any season from November 1997-December 1998 in the Allegheny Plateau physiographic province of West Virginia . . . . . . . . . . . . . . . . . . . . . . 92 


\section{LIST OF TABLES}

\section{CHAPTER 2.}

1. Common food items of Allegheny woodrats from the Ridge and Valley of West Virginia and Virginia and Allegheny Plateau of West Virginia from November 1997 through

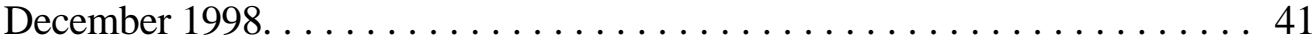

2. Average percent consumed of major food categories eaten by Allegheny woodrats by season between November 1997 and December 1998 in the Ridge and Valley and Allegheny Plateau physiographic provinces of West Virginia and Virginia . . . . 42

3. Average percent consumed of major food categories eaten by male and female Allegheny woodrats by season between November 1997 and December 1998 in the Ridge and Valley and Allegheny Plateau physiographic provinces of West Virginia and Virginia .. 43

\section{CHAPTER 3.}

1. Means of 42 microhabitat habitat variables collected within 0.04 ha plots centered around known Allegheny woodrat foraging locations by harvesting method at the Westvaco Wildlife and Ecosystem Research Forest, Randolph County, WV, 1998-99. .......................... 67

2. Foods found in the diets of Allegheny woodrats from November 1997- December 1998 from uncut forests, diameter-limit harvests, and clearcuts in the Allegheny Plateau of West Virginia ............................ 70 


\section{LIST OF FIGURES}

CHAPTER 1.

1. Fecal sample collection sites in the Ridge and Valley and Allegheny Plateau physiographic provinces of West Virginia and Virginia, 1997-1998 . . . . . . . . . . . . 19

\section{CHAPTER 2.}

1. Fecal sample collection sites in the Ridge and Valley and Allegheny Plateau physiographic provinces of West Virginia and Virginia, 1997-1998 . . . . . . . . . . . . . 44

\section{CHAPTER 3.}

1. Locations of clearcut, intact forest, and diameter-limit stands on the Westvaco Wildlife and Ecosystem Research Forest and surrounding Westvaco properties in Randolph Co.,

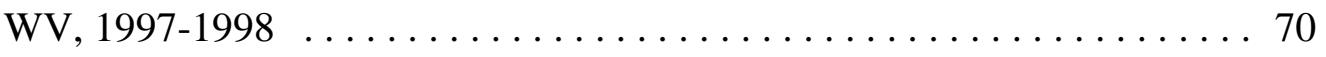




\section{CHAPTER 1}

\section{INTRODUCTION AND LITERATURE REVIEW}

\section{INTRODUCTION}

The Allegheny woodrat is a medium-sized rodent species closely tied to rock outcrops, cliffs, talus slopes, boulder fields, and caves within the central and southern Appalachians. The distributional range extends from southeastern New York in the north, extreme southern Indiana and southern Ohio in the west, to the Tennessee River Valley in the south (Newcombe 1930, Poole 1940, Wiley 1980, Hall 1981). This species was first described from skull fragments found in Pennsylvania caves (Baird 1857). Similarly, Stone (1893) described Neotoma pennsylvanica as a new species from 2 female woodrats captured in Pine Grove, Pennsylvania. The specific epithet pennsylvanica was placed in synonymy of magister by Rhodes (1894). However, this classification was not accepted (Mearns 1898, Miller 1899, Rhoads 1903) until the revision of the genus Neotoma by Goldman (1910). From the 1950's until the late 1980's, magister was considered a subspecies of the Eastern woodrat (Neotoma floridana) based on cranial and external morphologic analysis (Schwartz and Odum 1957). Recent morphometric and genetic analysis by Hayes (1990), Hayes and Harrison (1992), Hayes and Richmond (1993) and Planz et al. (1996) have supported the initial classification that the Allegheny woodrat is indeed distinct from the Eastern woodrat.

The Allegheny woodrat is currently listed as threatened, endangered, or as a species of special concern in Indiana, Maryland, New Jersey, New York, North Carolina, Ohio, Pennsylvania, Virginia, and West Virginia (Mengak 1996). Throughout the range, it occurs on more state endangered and threatened species lists than any other rodent in the United States (Beans 1992). Prior to the federal moratorium on endangered species listing, this species was designated as a candidate Category II animal in response to apparent population declines in the periphery of its range (Balcom and Yahner 1996). 
Multiple reasons are suspected as the ultimate causes for decline. In the northern extent of the range, exposure as a secondary host to the ascarid roundworm (Baylisascaris procyonis) from increased contact with raccoons (Procyon lotor) may play a significant role (Beans 1992, McGowan and Hicks 1996). Severe weather (eg. drought or long, harsh winters), may also contribute to Allegheny woodrat population declines, especially successive years of bad weather or when exacerbated by other mortality factors, such as disease or starvation. In some areas, population reductions may be large enough to cause localized extirpations or allow otherwise benign factors to become serious mortality agents (Fitch and Rainey 1956, Nawrot and Klimstra 1976). Other hypotheses include increased predation from avian and medium-sized mammalian predators and increased agriculturalization and/or suburbanization in valley and midslope areas that formerly served as habitat corridors between colony sites (Dunn et al. 1989, Balcom and Yahner 1996).

Several proximal factors affecting the availability of food resources may contribute to localized population declines. Reduction of annual hard mast crops resulting from chestnut blight (Cryphonectria parasitica) and/or gypsy moth (Lymantria dispar) infestations of oak (Quercus spp.) stands (Hall 1988), changes in plant species composition due to increased deer herbivory (Hassinger et al. 1996), and short-rotation forest management, also may be contributing factors. Even-aged silviculture discriminates against traditional and buffer mast producers such as American beech (Fagus grandifolia), hickory (Carya spp.), elm (Ulmus spp.), maple (Acer spp.), and buckeye (Aesculus spp.). Conversely, even-aged silviculture is necessary to promote/regenerate most hard and soft mast producing species like oak and cherry (Prunus spp.), however, it can take 10-30 years for mast production to begin and 30-100 years to reach maximum production (Marquis 1990, Sander 1990a,b; Auchmoody et al. 1993, Hicks 1998). In Louisiana, Neal (1967) found a direct correlation between mast failures and a rapid decline in Eastern woodrat densities. Each of the aforementioned factors can work singularly, however, multiple factors may operate in a synergistic manner.

Woodrat population declines appear to be most prevalent in the northern and western extents of the distributional range. In eastern Pennsylvania, woodrats are absent from many historic colony sites (Hall 1988, Hassinger et al. 1996). Populations in New Jersey, Ohio, and Indiana have 
experienced similar declines and colonies in New York are now extirpated (Hicks 1989). The current status and distribution in the southern extent of the range in Kentucky and Tennessee is uncertain. Anecdotal evidence suggests that populations are stable on the Cumberland Plateau and Highland Rim subsections of both states, with an apparent extirpation of the species within the Blue Ridge of Tennessee (R. P. Wyatt, Tennessee Wildlife Resources Agency, pers. comm. 1996). Allegheny woodrat populations in Virginia and West Virginia, the core of the distributional range, appear stable, although actual population status is unknown (Mengak 1996, Stihler and Wallace 1996).

Management paradigms for Allegheny woodrats have been and are being formulated based on information collected in areas removed from the core distributional range. Management implications drawn from peripheral areas of the range may not be valid in states where populations are more stable. Before appropriate management guidelines can be developed, information concerning ecological requirements, especially food habits, is needed (Hall 1985). To gain a better understanding of the feeding ecology of the Allegheny woodrat, I examined:

1. seasonally important food items in both the Ridge and Valley and Allegheny Plateau physiographic provinces of West Virginia and Virginia;

2. differences in food habits between the hard-mast driven systems of the Ridge and Valley versus non-mast driven systems in the Allegheny Plateau; and

3. the effects of timber management practices on the food habits of the Allegheny woodrat in the Allegheny Plateau.

\section{LITERATURE REVIEW}

Woodrats are considered generalist herbivores that consume a variety of fruits, nuts, and green vegetation (Rainey 1956, Post 1993). Several authors have examined the food habits of the eastern woodrat throughout the range (Bailey 1905, Howell 1921, Rainey 1956). Woodrats have been reported to feed on animal matter, though this has never been reported as a dominant food item (Poole 1940, Vorhies and Taylor 1940, Linsdale and Tevis 1951, Murphy 1952, Fitch and Rainey 1956, Wooley 1981, Horne 1996, Williams 2000). Fungi are consumed extensively by woodrats when 
available (Parks 1922, Newcombe 1930, Poole 1940, Dalquest 1948, Linsdale and Tevis 1951, Finley 1958). Dried fungi represents a good source of protein, carbohydrates, and minerals (Fogel and Trappe 1978).

Limited data on food habits of the Allegheny woodrat have been gathered from direct observations and from cached items in woodrat middens. From Pennsylvania, Poole (1940) listed materials found in and about nests of Allegheny woodrats, with some assumed to be food items. Other potential food items have been described from feeding observations of captive woodrats (Poole 1936, 1940; Pearson 1952, Rainey 1956). Poole (1940) presented a limited list of 10 food items compiled from the viscera of a few freshly collected Allegheny woodrats. However, no extensive examinations of stomachs or fecal material from woodrats in the wild have been performed for this species.

Acorn availability is an important factor affecting the growth and survival of young and maintaining body weights of adults in other rodents such as the white footed mouse (Peromyscus leucopus; Batzli 1977, Hansen and Batzli 1978) and gray squirrel (Sciurus carolinensis; Nixon et al. 1968, Nixon et al. 1975). Gray squirrels were found to depend heavily on cached hickory, beech, and oak mast during the winter months. The importance of mast has been extensively documented for several species that occur throughout the Appalachian region such as black bear (Ursus americanus; Beeman and Pelton 1977, Garshelis 1978, Garshelis and Pelton 1980, Eagle and Pelton 1983), whitetailed deer (Odocoileus virginianus; French 1985, French et al. 1986, Pekins and Mautz 1987, Feldhamer et al. 1989, Wentworth et al. 1990a, b), wild boar (Sus scrofa; Bennett et al. 1943, Conley et al. 1972, Bratton et al. 1982), and game birds such as wild turkey (Meleagris gallopavo) and grouse (Bonasa umbellus; Korschgen 1967, 1973; Williams 1986, Servello and Kirkpatrick 1988). Wagle (1996) found that eastern woodrats in southern Illinois relied heavily on hard mast throughout the year and were not selective in the type of mast they consumed. Hard mast comprised $\geq 60 \%$ of the cumulative diet each season. Research is needed to determine the importance of acorns and other mast to Allegheny woodrats (Balcom and Yahner 1996).

Mammals that rely on cached foods in the dormant season, such as Allegheny woodrats, are faced with foraging decisions that relate to both short- and long-term optimization (Katz 1974, Pyke et 
al. 1977, Craig et al. 1979). According to optimal foraging theory, a forager should only consume preferred food items if there are enough of those food items to fulfill daily nutritional and energy requirements. This ensures those food items are not lost to competitors (Pyke et al. 1977, Reichman and Fay 1983). As highly preferred food items are depleted, foragers should include the next highest quality item, resulting in a somewhat homogeneous diet. For animals that depend on cached foods during the dormant season, consuming and foraging must be considered separate strategies (Reichman 1988). Cached foods should be chosen because of availability, nutrient and energy content (Post 1993), and perishability (Reichman 1988). Therefore, when caching, woodrats are expected to collect and consume a diverse diet to ensure they have access to high quality food items at the end of the cache dependent period (Reichman and Fay 1983).

Woodrats typically forage in the immediate vicinity of the nest in spring and summer (Fitch and Rainey 1956 ). For eastern woodrats, caching begins in September or October and dominates all other activities until the onset of winter (Nawrot and Klimstra 1976). Cached materials are the primary food source during winter but limited foraging still occurs, presumably to avoid being left with poor quality foods before the cache can be restocked. Woodrats often store more food than they can consume in winter such that leftover material is still present when caching begins in the next growing season.

Trends in forest utilization suggest an increased level of management within the range of the Allegheny woodrat. Because current forest management practices may be affecting available food resources, forest managers both in the public and private sectors increasingly need information regarding management impacts. Knowledge of food habits is vital for successful long-term management of most wildlife species (Bump et al. 1947, Korschgen 1962, Korschgen 1967, Goodrum et al. 1971, Nixon et al. 1975, Pelton 1983, Nixon and Hansen 1987). In addition, translocation of both Allegheny and eastern woodrats into formerly occupied habitats has been investigated as a possible management tool to aid in population recovery (Schlie and Bookhout 1985, McGowan 1993, Wagle and Feldhamer 1997). Numerous considerations, including potential food resource needs, are crucial 
for successful reintroduction efforts. Therefore, methods of assessing food habits should be as accurate and representative as possible.

Historically, wildlife food habits have been described by direct observations of foraging animals, examination of characteristic cuttings, and from items found buried or cached. These methods are often unrealistic, biased, or difficult under field conditions. Food habits of captive specimens are not always representative of individuals under natural conditions because of modified feeding behavior (Hamilton 1941). Microhistology has been used to identify food habits following technique development by Baumgartner and Martin (1939). The utility of microhistological techniques stems from the resistance of plant epidermis to digestion. Accordingly, plant species can be recognized on the basis of epidermal features such as stomata size, arrangement and shape, the presence of trichomes, their morphology and density, cell wall ornamentation, and the presence and position of specialized cells and crystals in stomach or fecal samples. Fecal analysis has several advantages over stomach content analysis. Obtaining fecal samples does not necessarily require animal death or disturbance and the population may be resampled over time. These advantages are especially important when working with threatened, endangered, or species of special concern. However, the use of fecal samples also has disadvantages. The digestive process may break down the cuticle of different plant species at different rates and certain species may be under- or over-estimated or even missed altogether (Storr 1961, Slater and Jones 1971, Dunnet et al. 1973). Additionally, the similarity of surface cell characteristics between species or genera may cause difficulty in identification or misidentifications (Nelson and Davitt, pers. comm.). Wydeven and Dahlgren (1982) found that all species of plant items present in amounts $>1 \%$ in stomachs of black-tailed prairie dogs (Cynomys ludovicianus) were present in at least trace amounts in the feces. Generally, only a few rare species in stomachs are not detected in the feces (Stewart 1970, Wydeven and Dahlgren 1982).

\section{DESCRIPTION OF STUDY AREA}

The range of the Allegheny woodrat falls predominantly within the Central Hardwood region. The Central Hardwood region is the largest contiguous, temperate hardwood forest in the world (Hicks 
1998). It covers more than $608,500 \mathrm{~km}^{2}$ within the unglaciated east-central United States and is centered along the axes of the Appalachian Mountains east of the Mississippi River and the west to the OuachitalOzark Mountains. Private, nonindustrial landowners own 77\% of the regional forestland. Of the remaining $23 \%$, approximately $9 \%$ is national forest, $5 \%$ is owned by industry, and approximately 9\% is other public land (Barrett 1995). Locally in West Virginia and western Virginia, the portion of public land and private industrial land is much more extensive than the rest of the Central Hardwood region. This provides a unique opportunity to study woodrats in a primarily forested landscape.

Second-growth hardwoods dominate the woody vegetation of the region, although conifers may be locally important components (Hicks 1998). No single tree species dominates the central hardwood region, but oaks constitute a larger proportion of the growing stock than any other species or genus (Belt et al. 1992). In the mountainous portions of the Central Hardwood region, the effects of elevation, aspect and slope produce a mosaic across the landscape with northern hardwoods at higher elevations, oaks on south-facing aspects and lower ridges, and mixed mesophytic hardwoods predominating on northern aspects and sheltered coves ( Smith 1986, Barrett 1995, Hicks 1998).

Within the Central Hardwood region there are 6 major physiographic provinces; the Appalachian Plateau, Ridge and Valley, Central Lowland/Interior Low Plateaus, Ozark Plateau, Ouachita Mountains, and Blue Ridge (Fenneman 1938). The physiography of any area is a function of several factors such as underlying geology, tectonic movement, climate, and time (Hicks 1998). Each of these factors has a direct impact on the types of vegetation that will occupy a site. My research focused on woodrats within the core of the distributional range which is largely within the Ridge and Valley physiographic province and Allegheny Plateau subsection of the Appalachian Plateau. Although these provinces are in close proximity, each differs with regard to physiography, geology, and climate. As a result, vegetational differences between sites may cause differences in the composition and distribution of woodrat food resources. 


\section{The Allegheny Plateau}

The Allegheny Plateau receives an average of 168-190.5 cm of precipitation a year (Barrett 1995). The drainage pattern is dendritic as a result of the severely dissected, steep slopes and narrow valleys (Fenneman 1938). Slopes are commonly divided by shelves of interbedded sandstone and shale that exhibit differing weathering rates. The flat, broad-topped ridges are composed of resistant rock whereas the valleys developed on weaker strata (Fenneman 1938, Braun 1950).

Within the Allegheny Plateau, I focused my research efforts in the Allegheny Mountains portion described by Braun (1950). The forest composition varies among locations and altitudinal transitions, ranging from mixed mesophytic to northern forests. In elevations above $900 \mathrm{~m}$, oaks and mesophytic hardwood species are replaced by northern hardwoods such as beech, birch (Betula spp.), and maple (Braun 1950). At the highest elevations, above $1200 \mathrm{~m}$, and within sheltered frost pockets and riparian areas as low as $800 \mathrm{~m}$, relictual, montane red spruce (Picea rubens)-eastern hemlock (Tsuga canadensis) forests replace northern hardwoods (Braun 1950). At lower elevations, mixed mesophytic species such as yellow-poplar (Liriodendron tulipifera), northern red oak (Quercus rubra), American basswood (Tilia americana), and black birch (Betula lenta) can be found. Rosebay rhododendron (Rhododendron maximum), mountain laurel (Kalmia latifolia), and greenbrier (Smilax spp.) are common in the understories across all forest types.

My study sites were located on the 3,630 ha Westvaco Wildlife and Ecosystem Research Forest (WWERF) and surrounding Westvaco Corporation properties in Randolph County, West Virginia (Fig. 1). In 1994, the site was designated a research area to examine the effects of intensive industrial forest management on Appalachian ecosystems. Elevations on the WWERF range from 740$1,200 \mathrm{~m}$. The area contains actively managed second or third growth forests, where northern hardwood communities predominate. Woodrat colony sites are generally found along ridgetops in sandstone outcrops. Due to constant freezing and thawing, abundant cave-like fissures and crevices developed along the outcrops that are frequently used by Allegheny woodrats as den sites.

Timber harvest methods commonly employed on the WWERF include two-aged regeneration harvests, clearcutting, and diameter-limit harvests. The method used on a stand is determined by 
management objectives, site quality, and stand age. Two-aged regeneration harvests remove all trees except 6-10 residual trees/ha which are retained until the next harvest. This method is commonly used when wildlife or aesthetics are important (Barrett 1995). Clearcutting removes all tress $<2.54 \mathrm{~cm} \mathrm{dbh}$ and is used to promote the growth of fast growing, early successional species. Clearcuts and two-aged regeneration harvests are followed by an abrupt surge of growth from sprouts (Ripley and Campbell 1960, Della-Bianca and Johnson 1965, Moore and Downing 1965, Wentworth et al. 1990b, Ford et al. 1993). A diameter-limit harvest extracts high quality sawlogs $>40 \mathrm{~cm}$ dbh and generally is not considered a silviculturally accepted management technique (Smith 1986), but is commonly used throughout the Appalachian region.

\section{The Ridge and Valley}

The Ridge and Valley physiographic province consists of a group of narrow, long, well defined ridges and valleys situated between the Blue Ridge and Allegheny Plateau physiographic provinces. My colony sites occurred in the middle section where ridges and valleys form a nearly continuous band running northeast to southwest (Fenneman 1938). This section is old and geologically complex. Rock outcrops are common, with heavily folded rock strata that range from strongly inclined to nearly vertical (Barrett 1995). In addition, boulder fields and exposed talus slopes used by Allegheny woodrats are common below outcrops. Elevations range from less than $600 \mathrm{~m}$ to more than 1,370 $\mathrm{m}$ (Fenneman 1938, Barrett 1995) and the valley floors range from $300 \mathrm{~m}$ to $610 \mathrm{~m}$ below the adjacent ridges (Barrett 1995). The Ridge and Valley lies in the rain shadow of the Allegheny Mountains creating more xeric conditions. Annual precipitation ranges from approximately 127-168 cm (Hicks 1998).

The Ridge and Valley physiographic province falls within the Oak-Chestnut Forest Region described by Braun (1950). This area was formerly a chestnut (Castanea dentata)-chestnut oak $(Q$. prinus) forest (Braun 1950), but few chestnuts still exist past the sprout stage due to chestnut blight infection. Oaks are prevalent on ravine slopes. Hemlock communities and mixed forests with hemlock, beech, yellow-poplar, red maple (A. rubrum), red oak, white oak (Q.alba) and sometimes sugar maple (A. saccharum), basswood, and white pine (Pinus strobus) are limited to the most mesic sites 
such as sheltered north facing coves and ravines (Braun 1950). Along ridgetops, where Allegheny woodrats are commonly found, and on southwest facing slopes, xeric-adapted oaks, mountain laurel thickets, mixed pine-hardwood communities, and open, savannah-like shale barren communities are common. Colony sites are often surrounded by a dense shrub layer of mountain laurel and greenbrier.

Study sites were located in the Greenbrier State Forest and surrounding Westvaco Corporation lands in eastern Greenbrier County, West Virginia, and the nearby George Washington and Jefferson National Forests in western Allegheny, Bath, and Giles Counties, Virginia (Fig. 1). All collection sites occurred in mature, second-growth oak-pine forests, although 2 sites on Westvaco property occurred in close proximity to recent clearcuts and one on the Greenbrier State Forest was located on the edge of a wildlife food plot.

\section{LITERATURE CITED}

AuCHMOODY, L. R., H. R. SMITH, AND R. S. WALTERS. 1993. Acorn production in northern red oak stands in northwestern Pennsylvania. USDA, Forest Service, Res. Pap. NE-680. 5pp.

BAILEY, V. 1905. Biological Survey of Texas. North American Fauna. 25:109.

BAIRD, S. F. 1857. Mammals of North Amer., p. 498 (in account of Neotoma occidentalis).

BALCOM, B. J., AND R. H. YAHNER. 1996. Microhabitat and landscape characteristics associated with the threatened Allegheny Woodrat. Cons. Biol. 10:515-525.

BARRETT, J. W. 1995. "The Southern Appalachian Hardwood Region” in Regional Siviculture of the United States. John Wiley and Sons, Inc. New York. 643 pp.

BATZLI, G. O. 1977. Population dynamics of the white-footed mouse in floodplain and upland forests. American Midland Naturalist. 97:18-32.

Baumgartner, L. L., AND A. C. MARTin. 1939. Plant histology as an aid in squirrel food-habits studies. J. Wildl. Manage. 3:266-268.

BEANS, B. E. 1992. Without a trace: The puzzling demise of the Allegheny woodrat. Audubon. 92:32-34. 
BEEMAN, L. E., AND M. R. PELTON. 1977. Seasonal foods and feeding ecology of black bears in the Smokey Mountains. Internat. Conf. on Bear Res. and Manage. 4:141-147.

Belt, R. C., N. D. Cost, N. P. Kingsley, AND J. R. Peters. 1992. Timber volume maps for the eastern United States. USDA, Forest Service, Gen. Tech. Rept. WO-60. 59 pp.

BENNETT, L. J., P. F. ENGLish, AND R. L. WATTS. 1943. The food habits of the black bear in Pennsylvania. J. Mammal. 24:25-31.

Bratton, S. P., M. E., HARMON, AND P. S. White. 1982. Patterns of European wild boar rooting in the western Great Smokey Mountains. Castanea, 47:230-242.

BRAUn, E. L. 1950. Deciduous forest of Eastern North America. Blakiston, Co., Philadelphia, PA. 596 pp.

BUMP, G., R. W. DARROW, F. C. EDMINSTER, AND W. F. CRISSEY. 1947. The ruffed grouse: life history, propagation, and management. New York State Cons. Dept. 951 pp.

CONLEY, R. H., V. G. HENRY, AND G. H. MATSChKE. 1972. European hog research. Final report Federal Aid Proj. W-34. Tennessee Wildl. Res. Agency. Nashville. 259 pp.

Craig, R. B., D. L. DeAANGelis, AND K. R. DixON. 1979. Long- and short-term dynamic optimization models with application to the feeding strategy of the loggerhead shrike. Am. Nat. $113: 31-51$.

Dalquest, W. W. 1948. Mammals of Washington. Univ. Kans. Mus. Nat. Hist. Publ. 2:1-444.

Della-BIANCA, L., AND F. M. JohNSON. 1965. Effect of an intensive cleaning on deer-browse production in the Southeastern Appalachians. J. Wildl. Manage., 29:729-733.

DunN, J., J. HALl, AND T. WilKINSON. 1989. Report of woodrat survey trapping. Appendix 2 and 3. Woodrat Subcommittee, Pennsylvania Game Commission, Harrisburg.

DUNNET, G. M., A. E. HARVIE, AND T. J. SMIT. 1973. Estimating the proportions of various leaves in the diet of the opossum Trichosurus culpecula Kerr, by fecal analysis. J. Appl. Ecl. 10:737745 .

EAGLE, T. C., AND M. R. PELton. 1983. Seasonal nutrition of black bears in the Great Smokey Mountains National Park. Internat. Conf. on Bear Res. and Manage. 6:94-101. 
FEldHAMER, G. A., T. P. KILBANE, AND D. W. ShaRP. 1989. Cumulative effect of winter on acorn yield and deer body weight. J. Wildl. Manage. 53:292-295.

FEnNEMAn, N. M. 1938. Physiography of the Eastern United States. McGraw-Hil, New York. $714 \mathrm{pp}$.

FINLEY, R. B., JR. 1958. The wood rats of Colorado: distribution and ecology. Univ. Kans. Mus. Nat. Hist Publ. 10:213-552.

FITCH, H. S. AND D. G. RAINEY. 1956. Ecological observations on the woodrat, Neotoma floridana. Univ. Kansas Publ., Mus. Nat. Hist. 8:499-533.

FOGEL, R., AND J. M. TRAPPE. 1978. Fungus consumption (mycophagy) by small animals. Northwest Science. 52:1-31.

Ford, W. M., A. S. Johnson, P. E. HALE, AND J. M. WENTwORTH. 1993. Availability and use of spring and summer woody browse by deer in clearcut and uncut forests of the Southern Appalachians. South. J. Appl. For. 17:116-119.

FRENCH, J. R. 1985. Oak mast availability and use by large mammals in eastern Tennessee. M. S. Thesis, Univ. Georgia, Athens. 76 pp.

, AND P. E. Hale, A. S. Johnson, AND J. M. Wentworth. 1986. Acorn availability and use by deer in eastern Tennessee. Southeastern Deer Study Group Meet. 9:7.

GARSHELIS, D. L. 1978. Movements, ecology, and activity behavior of black bears in the Great Smokey Mountains National Park. M. S. Thesis, Univ. of Tennessee, Knoxville. 117 pp. , AND M. R. PELTON. 1980. Activity of black bears in the Great Smokey Mountains National Park. J. Mammal. 61:8-19.

Goldman, E. A. 1910. Revision of the wood rats of the genus Neotoma. North American Fauna. $31: 82-86$.

GoOdRUM, P. D., V. H. REID, AND C. E. BOYD. 1971. Acorn yields, characteristics and management criteria of oaks for wildlife. J. Wildl. Manange. 35:520-532.

HALL, E. R. 1981. The mammals of North America. 2nd Ed. John Wiley and Sons, New York. 
HALL, J. S. 1985. Threatened eastern woodrat Neotoma floridana (Ord) Family Cricetidae, Order Rodentia. Special Pub. Carnegie Mus. Nat. Hist. 11:362-365. 1988. Survey of the woodrat in Pennsylvania. Final Report. Pennsylvania Game Commission, Harrisburg, Pennsylvania.

HAMILTON, W. J., JR. 1941. Food of small forest mammals in eastern United States. J. Mammal. 21:250-263.

HANSEN, L., AND G. O. BATZLI. 1978. The influence of food availability on the white-footed mouse: populations in isolated woodlots. Canadian J. of Zoo. 56:2530-2541.

HASSINGER, J., C. BUTCHKOSKI, D. DiEFENBACH. 1996. Fragmentation effects on the occupancy of forested Allegheny woodrat (Neotoma magister) colony areas. Unpub. Rept.

HAYES, J. P. 1990. Biogeographic, systematic, and conservation implications of geographic variation in woodrats of the eastern United States. Ph.D. Dissert., Cornell Univ., Ithaca, New York. , AND R. G. HARRISON. 1992. Variation in mitochondrial DNA and the biogeographic history of woodrats (Neotoma) in the eastern United States. Systematic Biol. 41:331-344. , AND M. E. RICHMOND. 1993. Clinal variation and morphology of woodrats (Neotoma) of the eastern United States. J. Mamm. 74:204-216.

HICKS, A. 1989. What happened to the Allegheny woodrat? Pages 34-38 in The conservationist (March-April), New York State Dept. of Environ. Cons., Albany.

HICKS, R.R., JR. 1998. Ecology and Management of Central Hardwood Forests. John Wiley and Sons, Inc. New York, NY.

HoRnE, E. A. 1996. Construction, use, and defense of a central food cache by the eastern woodrat, Neotoma floridana, Ph.D. Dissert., Kansas State Univ., Manhattan. 111pp.

Howell, A. H. 1921. A biological survey of Alabama. North Amer. Fauna. 45:53-54.

KATZ, P. L. 1974. A long-term approach to foraging optimization. Am. Nat. 108:758-782.

KORSCHEGEN, L. J. 1962. Foods of Missouri deer, with some management implications. J. Wildl. Mange. 26:164-172. 
1967. Feeding habits and foods. Pages 137-138 in O. H. Hewitt, ed. The wild turkey and its management. The Wildl. Soc., Washington D.C.

. 1973. April foods of wild turkeys in Missouri. Pages 143-150 in G. C. Sanderson and H. C. Schultz. Wild turkey management. Univ. Missouri Press., Columbia.

LinSDALE, J. M., AND L. P. TEVIS, JR. 1951. The dusky-footed woodrat. Univ. Of Calif. Press, Berkeley. 664pp.

MARQuIS, D. A. 1990. Prunus serotina Ehrh., black cherry. in Silvics of North America. Bol. 2., Hardwoods. Burns, R. M. and Honkala, B. H. (eds.). USDA, Forest Service, Agric. Handbook 654:594-604.

MCGowAN, E. M. 1993. Experimental release and fate study of the Allegheny Woodrat (Neotoma magister). Final report. Appendix I. Endangered Species Unit, New York State Dept. of Environ. Conserv., Delmar, New York.

, AND A. HICKS. 1996. Baylisascaris procyonis: the probable cause of extirpation of the Allegheny woodrat in New York State. page 4 in Abstracts of the 1996 Allegheny Woodrat Recovery Group Meeting., Ferrum College, Ferrum, Virginia.

MEARnS, E. A. 1898. Notes on the mammals of the Catskill Mountains, New York, with general remarks on the fauna and flora of the region. Proc. U.S. Nat. Mus. 21:334-335.

MENGAK, M. T. 1996. Status and distribution of woodrat metapopulations in Virginia. Pages 2-3 in Abstracts of the 1996 Allegheny Woodrat Recovery Group Meeting., Ferrum College, Ferrum, Virginia.

Miller, G. S. JR. 1899. Preliminary list of New York mammals. Bull. New York State Mus. 6:318.

MoORE, W. H., AND R. L. DownING. 1965. Some multiple-use benefits of even-aged management in the Southern Appalachians. Proc. Soc. Am. For. Conf. 227-229.

MURPHY, M. F. 1952. Ecology and helminths of the osage wood rat, Neotoma floridana osagensis, including the description of Longistriata neotoma n. sp. (Trichostronblidae). Amer. Midl. Nat. 48:204-218. 
NAWrot, J. R. AND W. D. Klimstra. 1976. Present and past distribution of the endangered southern Illinois woodrat (Neotoma floridana illioensis). Chicago Academy Sci. Nat. Hist. Misc. 196:1-12.

NEAL W. A. 1967. A study of the ecology of the woodrat in the hardwood forests of the lower Mississippi river basin. M.S. Thesis. Louisiana State Univ.

NEWCOMBE, C. L. 1930. An ecological study of the Allegheny wood rat. J. Mammal. 11:204-211.

NIXON, C. M., AND L. P. HANSEN. 1987. Managing forests to maintain populations of gray and fox squirrels. Ill. Dept. Conserv. Tech. Bull. 5. Springfield. 35pp.

, D. M. WORLEY, AND M. W. MCCLAIN. 1968. Food habits of squirrels in southeast Ohio. J. Wildl. Manage. 32:294-305.

, M. W. MCClain, AND R. W. DONOHOE. 1975. Effects of hunting and mast crops on a squirrel population. J. Wildl. Manage. 39:1-25.

PARKS, H. E. 1922. The genus Neotoma in the Santa Cruz Mountains. J. Mammal. 3:241-253.

PEARSON, P. G. 1952. Observations concerning the life history and ecology of the woodrat, Neotoma floridana floridana (Ord). J. Mammal. 33:459-463.

PEKINS, P. J., AND W. W. MAUTZ. 1987. Acorn usage by deer; significance of oak management. North. J. Appl. For. 4:124-128.

Pelton, M. R. 1983. Movements. Pages 134-180 in D. M. Carlock, R. H. Conley, J. M. Collins, P. E. Hale, K. G. Johnson, A. S. Johnson, and M. R. Pelton. eds. Tri-state Black Bear Study. P.R. Tech. Rep. No. 83-9, 286pp.

PlanZ, J. V., E. G. Zimmerman, T. A. SPRADling, AND D. R. AKINS. 1996. Molecular phylogeny of the Neotoma floridana species group. J. Mamm. 77:519-535.

Post, D. M. 1993. Detection of nutrient concentration by Eastern woodrats (Neotoma floridana). J. Mammal. 74:493-497.

PoOLE, E. L. 1936. Notes on the young of the Allegheny wood rat. J. Mammal. 17:22-26. , 1940. A life history sketch of the Allegheny woodrat. J. Mammal. 21:249-270. 
PyKe, G., H. R. Pulliam, AND E. L. CharnOV. 1977. Optimal foraging: a selective review of theory and tests. Q. Rev. Biol. 52:137-154.

RAINEY, D. G. 1956. Eastern woodrat: Neotoma floridana: life history and ecology. Univ. Kansas Publ., Mus. Nat. Hist. 8:369-375.

REICHMAN, O. J. 1988. Caching behavior of eastern woodrats, Neotoma floridana, in relation to food perishability. Anim. Behav. 36:1525-1532.

, AND P. FAY. 1983. Comparison of the diets of a caching and noncaching rodent. Am. Nat. 122:576-581.

RHOADS, S. N. 1894. A contribution to the life history of the Allegheny cave rat, Neotoma magister Baird. Proc. Acad. Nat. Sci. Philadelphia, 1894, pp. 213-221.

, 1903. The mammals of Pennsylvania and New Jersey. pp.85-92.

RIPLEY, T. H., AND R. A. CAMPBELL. 1960. Browsing and stand regeneration in clear and selectivelycut hardwoods. Trans. Northeast. Wildl. Conf. 25:405-415.

SANDER, I. L. 1990a. Quercus rubra L., northern red oak. in Silvics of North America, Vol 2, Hardwoods. Burns, R. M. and Honkala, B. H. (eds). USDA, Forest Service, Agric. Handbook 654:727-733. 1990b. Quercus velutina, black oak. in Silvics of North America, Vol 2, Hardwoods. Burns, R. M. and Honkala, B. H. (eds). USDA, Forest Service, Agric. Handbook 654:727-733.

SCHLIE, W. J., AND T. A. BoOKHOUT. 1985. Reintroduction of Allegheny woodrats to Hocking County, Ohio. Ohio J. Sci. 85:92-93.

SchwartZ, A. AND E. P. OduM. 1957. The woodrats of the eastern United States. J. Mamm. 38:197-206.

SERVELlO, F. A., AND R. L. KIRKPATRICK. 1988. Nutrition and condition of ruffed grouse during the breeding season in southwestern Virginia. The Condor. 90:836-842.

SLATER, J., AND R. J. JONES. 1971. Estimation of the diets of selected grazing animals from microscopic analysis of the faeces- a warning. J. Aust. Inst. Agric. Sci. 37:238-239. 
SMITH, D. M. 1986. The practice of silviculture. Eighth edition. Wiley and Sons, New York, New York, USA. 527pp.

STEWART, D. R. M., 1970. Survival during digestion of epidermis from plants eaten by ungulates. Rev. Zool. Bot. Afr. 82:343-348.

STIHLER, C. AND J. WALlaCE. 1996. Woodrat studies in West Virginia. Page 2 in Abstracts of the 1996 Allegheny Woodrat Recovery Group Meeting., Ferrum College, Ferrum, Virginia.

Stone, W. 1893. Description of a new species of Neotoma from Pennsylvania. Proc. Acad. Nat. Sci. Philadelphia, 1893, pp. 16-18.

STORR, G. M. 1961. Microscopic analysis of faeces, a technique for ascertaining the diet of herbivorous mammals. Aust. J. Biol. Sci. 14:157-164.

VORHIES, C. T., AND W. P. TAYLOR. 1940. Life history and ecology of the white-throated wood rat, Neotoma albigula albigula Hartley, in relation to grazing in Arizona. Univ. Arizona, Coll. Agric., Tech. Bull. 86:455-529.

WAGLE, E. R. 1996. Population assessment and feeding habits of the eastern woodrat (Neotoma floridana) in southern Illinois. M.S. Thesis. Southern Illinois University, Carbondale. 76 pp. , AND G. A. FELDHAMER. 1997. Feeding Habits of the Eastern Woodrat (Neotoma floridana) in Southern Illinois. Transactions of the Illinois State Academy of Science. 90:171-177.

WENTWORTH, J. M., A. S. JohnSON, AND P. E. HALE. 1990a. Influence of acorn use on nutritional status and reproduction of deer in the Southern Appalachians. Proc. Annu. Conf. southeast. Assoc. Fish and Wildl. Agencies. 44:142-154. , and . 1990b. Seasonal use of Clearcuts and Food Plots by White-tailed Deer in the Southern Appalachians. Proc. Annu. Conf. Southeast. Assoc. Fish and Wildl. Agencies. 44:215-223.

WILEY, R. W. 1980. Neotoma floridana. Mammalian Species, No. 139.

WilliamS, C. K. 2000. Eastern Woodrat (Neotoma floridana) Consumption of Northern Bobwhite (Colinus virginianus). Am. Midl. Nat. 143:239-244.

WiLliamS, L. E., JR. 1986. The book of the wild turkey. Winchester Press. Tulsa, Oklahoma. 
WOOLEY, P. 1981. Evolution of defense strategies among three species of sympatric salamanders, Ph.D. Dissertation, Kansas State University, Manhattan. 125p.

WYDEVEN, P. R., AND R. B. DAHLGREN. 1982. A comparison of prairie dog stomach contents and feces using a microhistological technique. J. Wildl. Manage. 46:1104-1108. 


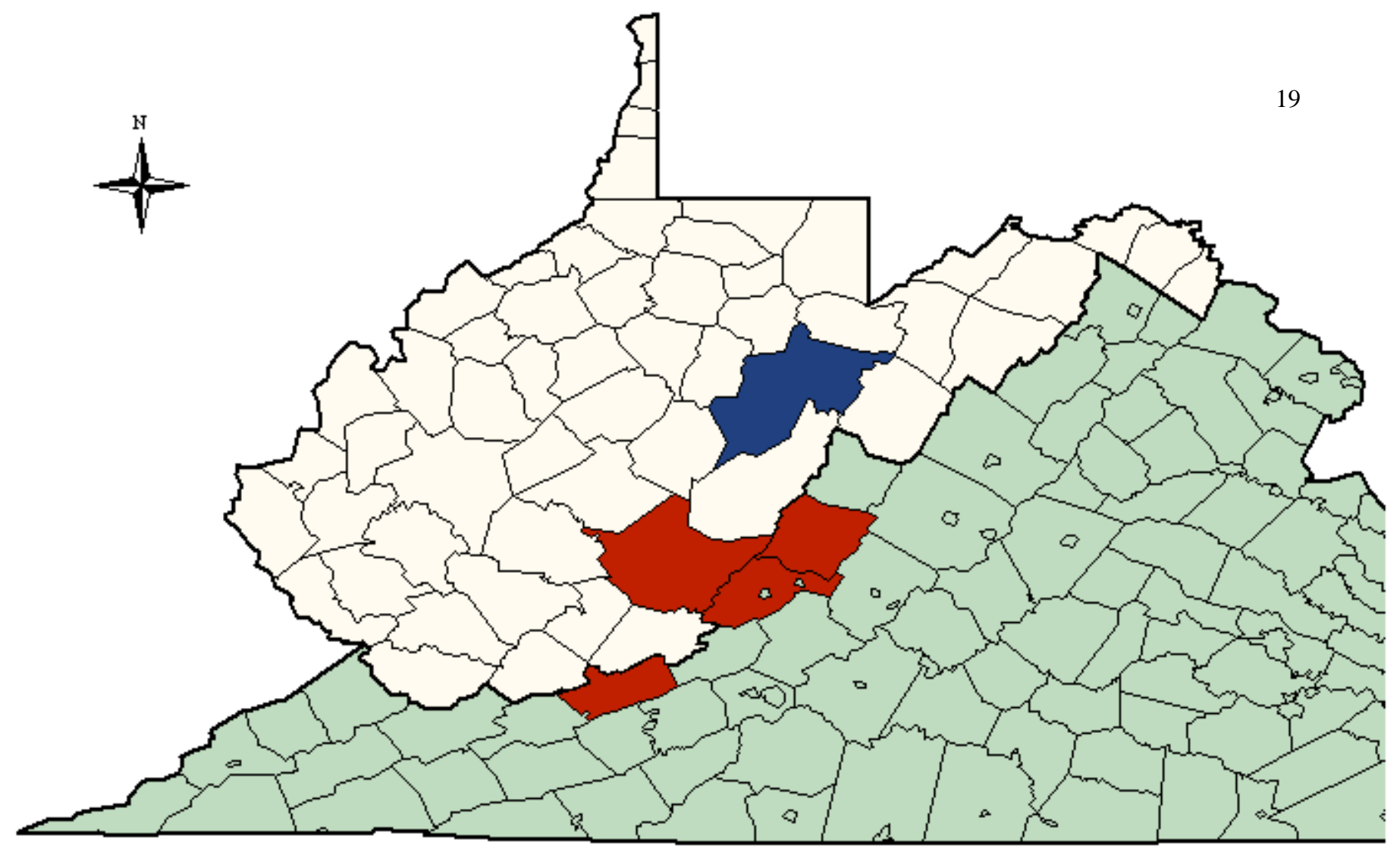

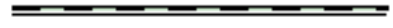

$100 \mathrm{~km}$
Legend

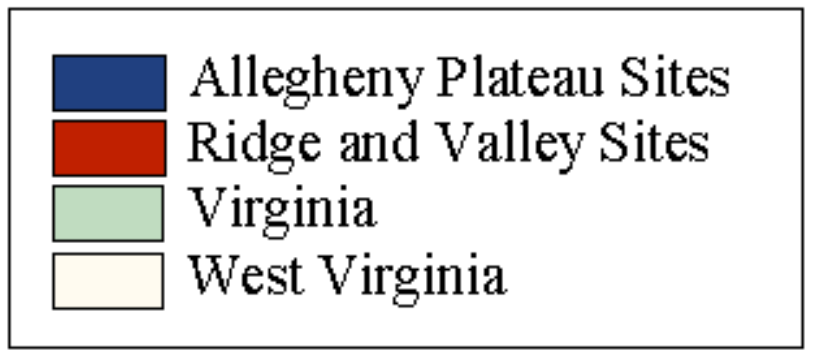

Figure 1. Fecal sample collection sites in the Ridge and Valley and Allegheny Plateau physiographic provinces of West Virginia and Virginia, 1997-1998. 


\section{CHAPTER 2}

\section{ALLEGHENY WOODRAT FOOD HABITS IN THE CENTRAL APPALACHIANS OF VIRGINIA AND WEST VIRGINIA}

Castleberry, N.L., W.M. Ford, P.B. Wood, and S.B. Castleberry. To be submitted to the American Midland Naturalist. 


\section{ABSTRACT}

Recent regional declines in Allegheny woodrat (Neotoma magister) populations suggest a better understanding of the basic ecology of this species is needed for proper management. Because current forest management practices may be affecting available food resources, managers are increasingly in need of information regarding changes in food resource availability and distribution. Fecal material was collected from known individuals between November 1997 and December 1998. We described the seasonal food habits of the Allegheny woodrat in the Ridge and Valley and Allegheny Plateau physiographic provinces using microhistological techniques. Total food item and species richness and diversity measures were also calculated. We examined differences among seasons and sexes within and between provinces. In the Allegheny Plateau, the top five food items were fungi, blueberries (Vaccinium spp.), oak acorns (Quercus spp.), ferns (Dryopteris spp.), and lichens. In the Ridge and Valley woodrats ate primarily blackberry (Rubus spp.) leaves, fungi, greenbrier (Smilax spp.) leaves, acorns, and oak leaves. Use of hard mast in the Ridge and Valley did not differ among seasons whereas in the Allegheny Plateau use of hard mast was higher in the fall of 1998 than any other season except fall 1997. The proportion of soft mast in the diet was higher in the Allegheny Plateau than the Ridge and Valley. Use of fungi was higher in the Allegheny Plateau than the Ridge and Valley in fall 1997 and winter 1998. In the Ridge and Valley, woodrats used more fungi in spring 1998 than fall 1997 and winter 1998, however, there were no differences among seasons in the Allegheny Plateau. Food habits of the Allegheny woodrat appeared to follow predicted patterns of optimal foraging strategies for both short- and long-term optimization. Although there were no significant differences in diversity values among seasons, the diversity of food items in the surrounding habitat was higher during the foraging period than when woodrats relied on cached foods. In the Ridge and Valley, species richness was higher in winter 1998 than in summer 1998. Female woodrats had higher total food item richness than males in fall 1997, whereas richness was higher for males in summer 1998. 
Key words: Allegheny woodrat, caching, central Appalachians, fecal analysis, food habits, fungi, mast, microhistology, Neotoma magister, optimal foraging strategy.

The Allegheny woodrat is a generalist rodent herbivore closely associated with rock outcrops, cliffs, talus slopes, boulder fields, and caves within the Central and Southern Appalachians. Small populations that occupy the same outcrop or other rocky habitat are referred to as colonies. Formerly, the species was distributed from the Catskill Mountains of southeastern New York down the Appalachian spine south to the Tennessee River Valley in Alabama and Tennessee and west across the mid-Ohio River Valley (Newcombe 1930, Poole 1940, Wiley 1980, Hall 1981). Currently, it is listed as threatened, endangered, or as a species of special concern in every state in which it occurs due to apparent population declines in the northern and western extents of the distributional range. In eastern Pennsylvania, New Jersey, Ohio, and Indiana, woodrats are absent from many historic colony sites and colonies in New York are now extirpated (Hall 1988, Hicks 1989, Beans 1992, Hassinger et al. 1996). However, the core of the distributional range falls predominantly within the Ridge and Valley and Allegheny Plateau physiographic provinces of West Virginia and Virginia where populations appear to be stable (Mengak 1996, Stihler 1996).

Several factors have been proposed as causes for the decline. They include severe weather (Fitch and Rainey 1956, Nawrot and Klimstra 1976), increased predation (Dunn et al. 1989, Balcom and Yahner 1996), reduced hard mast supply resulting from the chestnut blight (Cryphonectria parasitica) and gypsy moth (Lymantria dispar) infestations (Hall 1988), changes in plant species composition due to increased deer (Odocoileus virginianus) herbivory (Hassinger et al. 1996), parasitism by the raccoon roundworm (Baylisascaris procyonis) (Beans 1992, McGowan and Hicks 1996), and habitat fragmentation (Dunn et al. 1989, Balcom and Yahner 1996).

Management paradigms for Allegheny woodrats are being formulated based on information collected in areas removed from its core distributional range or from other woodrat species, assumed to be similar. Management implications drawn from areas on the periphery of the range may not be valid in areas where populations are more stable. Research in the core of the range will give information 
concerning basic ecological requirements, especially plant species required for food and nest building (Hall 1985).

Limited evidence of Allegheny woodrat food habits has been gathered from direct foraging observations and from items cached in woodrat middens, many assumed to be food items. Other lists of potential food items have been made from observations of captive woodrats (Poole 1936,1940; Pearson 1952, Rainey 1956). Poole (1940) identified food items from the viscera of a limited number of Allegheny woodrats, however, no extensive examinations of stomachs or fecal material from wild animals have been made.

To better understand the food resource requirements for this species, fecal samples from Allegheny woodrats were collected monthly from the Ridge and Valley and Allegheny Plateau physiographic provinces from November 1997-December 1998 to describe food habits using microhistological techniques. We identified seasonally important food items in both provinces, and examined differences in food habits from the mast driven systems of the Ridge and Valley versus nonmast driven systems in the Allegheny Plateau.

\section{STUDY AREA}

The Allegheny Plateau and Ridge and Valley physiographic provinces make up the core of the distributional range of the Allegheny woodrat where the effects of elevation, moisture, aspect, and slope, create a mosaic across the landscape. Each of these factors has a direct impact on the types of vegetation that will occupy a site. Although the Ridge and Valley and Allegheny Plateau are in close proximity, each differs with regard to physiography, geology, and climate. Differences in vegetation between sites may cause differences in food availability for woodrats.

Ridge and Valley study sites were located on the Greenbrier State Forest and surrounding Westvaco Corporation properties in Greenbrier County, West Virginia, and the George Washington and Jefferson National Forests in Allegheny, Bath, and Giles Counties, Virginia. The sites primarily were characterized by mature, second-growth forests, although two sites on Westvaco property occurred in close proximity to clearcuts and one on the Greenbrier State Forest was located on the 
edge of a wildlife food plot. Elevations range from < $600 \mathrm{~m}$ to more than 1,370 $\mathrm{m}$ (Fenneman 1938, Barrett 1995). The Ridge and Valley is located in the rain shadow of the Allegheny Mountains creating xeric conditions with annual precipitation ranging from 127-168 cm (Hicks 1998). Rock outcrops are common (Barrett 1995) with boulder fields and exposed talus slopes often occurring below outcrops. Oaks (Quercus spp.) are prevalent on ravine slopes (Braun 1950). Hemlock communities and mixed forests with hemlock (Tsuga canadensis), American beech (Fagus grandifolia), yellow-poplar (Liriodendron tulipifera), red maple (Acer rubrum), red oak (Q. rubra), white oak (Q. alba), and sometimes sugar maple (A. saccharum), basswood (Tilia spp.), and white pine (Pinus strobus) are limited to the most mesic sites such as sheltered coves and ravines (Braun 1950). Woodrats commonly are found along sideslopes and ridgetops, where vegetative communities consist of xeric-adapted oaks, such as chestnut oak (Q. prinus), scarlet oak (Q. coccinea), black oak (Q. velutina), and bear oak (Q. ilicifolia), mountain laurel (Kalmia latifolia) thickets, and mixed pine-hardwood communities (Strausbaugh and Core 1977). Colony sites often are surrounded by a dense shrub layer of mountain laurel and greenbrier (Smilax spp.).

Allegheny Plateau collection sites were located on Westvaco Corporations Wildlife and Ecosystem Research Forest (WWERF) in Randolph County, West Virginia. The site was designated in 1994 to examine the effects of intensive industrial forest management on Appalachian systems. The WWERF is a 3,630 ha managed forest dominated by 50-80-year-old second-growth stands. Although timber harvests are common, woodrats have a range of successional stages to choose from when foraging. Elevations range from 740-1,200 m and annual precipitation ranges between 168-190 cm (Barrett 1995). Woodrat colony sites are generally found along ridgetops in sandstone outcrops. Due to frequent freezing and thawing, fissures and crevices have developed that are used by woodrats as den sites. A Northern hardwood, beech-yellow birch (Betula lutea)-maple, black cherry (Prunus serotina) forest community predominates on the majority of the forest. At lower elevations, mixed mesophytic species such as yellow-poplar, northern red oak, American basswood (T. americana), and black birch (B. lenta) can be found. At the highest elevations and along sheltered riparian areas, red 
spruce (Picea rubens)-hemlock forests dominate. A dense growth of rosebay rhododendron (Rhododendron maximum), mountain laurel, and greenbrier are common midstory species.

\section{METHODS AND MATERIALS}

Fecal samples were collected monthly by live-trapping Allegheny woodrats in the Ridge and Valley and Allegheny Plateau physiographic provinces for 15 months to determine food habits using microhistological analysis. A minimum of 14 days separated each monthly trapping effort. Feces were collected from known animals by placing a canvas catchsheet under Tomahawk® live traps. All trapped animals were ear tagged for future identification and age, sex, and reproductive status were recorded. Fecal samples were preserved in 5\% formalin or 95\% Ethanol until analysis was conducted (Davitt and Nelson 1980).

Five random samples from each physiographic province were chosen for analysis each month. When woodrats were less active, such as in winter months, or difficult to capture due to poor weather conditions, and five samples could not be obtained, we used all samples collected for that time period and location. If five samples were unavailable for any month, samples from other months within the same season (if available) were used to obtain a total of 15 samples per season. Seasons were chosen to represent resource availability throughout the year. The winter (dormant season), spring (spring green up), summer (growing season), and fall (acorn drop) seasons included the calendar months December-February, March-May, June-August, and September-November, respectively.

Fecal material was analyzed at the Washington State University Wildlife Habitat and Nutrition Laboratory using techniques described by Baumgartner and Martin (1939) as modified by Davitt and Nelson (1980). One slide was made per sample and 20 fields-of-view were examined (Baumgartner and Martin 1939, McIntire and Carey 1989). A field-of-view was defined as the area delimited by the microscope field at 100X (Wydeven and Dahlgren 1982). Each diet component per field of view was recorded and all food items were described to the most specific taxon possible. In some cases, plant genera were pooled due to difficulty in distinguishing between similar cell structures (Appendix B-D). 
Reference slides to aid in food item identification were prepared at the Washington State University Wildlife and Nutrition Lab using potential food items collected during trapping and vegetation analysis of each site. Additionally, material found cached in middens was collected for reference material. Plants were dried for storage before preparation. Permanent slide mounts were prepared using modified techniques described by Davitt and Nelson (1980) for comparison to items found in feces. A complete list of all reference material is available in Appendix A.

Percent frequency of each plant item was determined using the frequency conversion technique (Sparks and Malechek 1968). This method determines the presence or absence of each species in each location using a frequency percent calculated as the number of fields that the species occurs in out of the total number of fields examined. This method is as accurate as particle density but does not require counting all recognizable fragments of each species in each location (Sparks and Malechek 1968, Holechek and Gross 1982).

Specific food items were described for each physiographic province and by season within physiographic provinces. For statistical analysis, food items were combined into the following descriptive categories: hard mast, soft mast, other seeds, fungi, lichens, buds, green vegetation, and insects. Hard mast was defined as fruit with a dry or hard exterior that is not wind disseminated (Huntley 1990). Soft mast was defined as fruit with a soft or fleshy exterior (Huntley 1990). Other seeds included all seeds that did not fit into either of the other seed/fruit categories (eg. maple (Acer spp.) sumaras, and elm (Ulmus spp.), pine (Pinus spp.), and sycamore (Platanus spp.) seeds. Green vegetation included all vegetative plant parts that did not fit into any of the above categories. Shannon diversity index (H') and species richness (total number of food items), were calculated for each treatment type (Shannon and Weaver 1963, Magurran 1988). Total food item richness and diversity were calculated as the total number of food items found in the diet regardless of species. For example, if woodrats ate acorns, leaves, and buds of an oak species, the richness value would be three. Species richness and diversity measured the total number of species present in the diet. Using the former example the richness value would be one. 
Comparisons were made among seasons, sexes, and provinces using 2-way analysis of variance (ANOVA). Because our data did not meet the assumptions of normality and homogeneity of variance and transformations were unsuccessful, ANOVA was performed on ranked (PROC RANK; SAS Institute 1990) data using general linear models (PROC GLM; SAS Institute 1990) with province, season, sex, and all possible interaction terms as fixed effects and the effect of individual nested within province and sex as a random effect. This procedure is the equivalent of a Kruskall Wallis non-parametric test, but allows for complex models and differing sample sizes between treatments (Sokal and Rohlf 1995). When differences $(\%=0.05)$ were detected, we used Tukey's Studentized Range (HSD) test to separate ranked means (Steel and Torrie 1980).

\section{RESULTS}

\section{Description of food habits by province}

We identified 147 food items consumed by woodrats in the Ridge and Valley and Allegheny Plateau physiographic provinces (Appendix B). For both provinces combined, the top five food items were fungi, blackberry (Rubus spp.) leaves, acorns, shield/wood ferns (Dryopteris spp.), and holly/blueberry fruit tied with lichen (Table 1). In fall 1997, woodrats relied most heavily on fungi, blackberry leaves, greenbrier fruit, wood/shield fern, and oak leaves. In winter 1998, the top five food items were wood/shield fern, blackberry leaves, blueberry leaves (Vaccinium spp.), fungi, and hemlock needles. In spring 1998, fungi was the most abundant food in the diet, followed by beech/birch buds, blackberry leaves, holly (Ilex spp.)/blueberry fruit, and greenbrier fruit. Fungi was the most frequently used food item in summer 1998 followed by lichen, acorns, blueberry leaves, and holly/blueberry fruit. In fall 1998, acorns made up the majority of the diet, followed by fungi, shield/wood fern, Christmas fern (Polystichum acrostichoides), and greenbrier leaves.

The top five food items in the Ridge and Valley across all seasons were blackberry leaves, greenbrier leaves, oak leaves, fungi, and wood/shield fern (Table 1). In fall 1997, the top five food items were blackberry leaves, oak leaves, fungi, magnolia leaves, cherry (Prunus spp.) leaves, and greenbrier leaves (Appendix B, C). Woodrats utilized blackberry leaves, wood/shield fern, cherry 
leaves, blueberry leaves, and greenbrier leaves most heavily in the winter of 1998. Fungi was the most abundant food item in spring 1998 diets followed by blackberry leaves, magnolia (Magnolia spp.) leaves, oak leaves, and greenbrier leaves. The summer (1998) diet was dominated by blackberry leaves, magnolia cones, blueberries, insect matter, and flower parts. Acorns dominated the diet in fall 1998, followed by greenbrier leaves, fungi, Christmas fern, and hemlock needles.

The top five food items in the Allegheny Plateau across all seasons were fungi, acorns, holly/blueberry fruit, acorns, wood/shield fern, and lichen (Table 1). In fall 1997, fungi made up the majority of the total diet, followed by wood/shield fern, greenbrier fruit, lichen, and blackberry fruit/seeds (Appendix B, D). The most frequently used food items in winter 1998 were hemlock needles, fungi, wood/shield fern, blueberry fruit, and Devils walking stick (Aralia spinosa). Beech/birch buds comprised the majority of the diet in spring 1998, followed by fungi, holly/blueberry fruit, greenbrier fruit, and rhododendron leaves. In summer 1998, lichen, fungi, holly/blueberry fruits, acorns, and blueberry fruit were the most common foods in the diet . The top food items in fall 1998 were acorns, fungi, wood/shield ferns, blueberry leaves, and holly/blueberry fruit.

Fruits (hard mast, soft mast, and other seeds) comprised a large portion of the diet of woodrats in both physiographic provinces (Table 2). Soft mast dietary composition was higher $(P<0.0067$, $d f=1,55, F=8.00)$ in the Allegheny Plateau than the Ridge and Valley for all seasons combined. Fungi, another important food item, was consumed more in the Allegheny Plateau during the fall of $1997(F=39.02, d f=1,50, P=0.0001)$ and winter of $1998(F=6.14, d f=1,50, P=0.021)$ than in the Ridge and Valley (Table 2). Lichens were consumed more frequently (fall 1997, $F=10.01, d f=1,50$, $P=0.0042$; spring $1998, F=4.64, d f=1,50, P=0.0410$; and summer $1998, F=7.14, d f=1,50$, $P=0.0151)$ in the Allegheny Plateau than the Ridge and Valley in all seasons except fall 1998 and winter 1998, although no lichens were consumed in fall 1997, winter 1998, or spring 1998 in the Ridge and Valley. Buds were used more frequently $(F=22.53, d f=1,55, P=0.0001)$ in the Ridge and Valley than the Allegheny Plateau. There were no differences in total food item or species diversity measures between provinces, although, species richness was higher $(F=5.60, d f=1,50, P=0.0268)$ in the Ridge and Valley than the Allegheny Plateau during winter 1998. 


\section{Season}

Fungi, an important food for many small mammal species, represented $\geq 9.7 \%$ of the diet in the Allegheny Plateau in every season with no significant differences between seasons (Table 2). In the Ridge and Valley, fungi was consumed in every season and represented $\geq 3.6 \%$ of the diet in three of five seasons. In the Ridge and Valley, use of fungi was greater $(F=7.4, d f=4,50, P<0.0001)$ in spring 1998 than fall 1997 or winter 1998.

Consumption of hard mast in the Allegheny Plateau was higher $(F=4.04, d f=4,50, P<0.0056)$ in fall 1998 than winter 1998, spring 1998, and summer 1998 (Table 2). Although hard mast use was highest in summer 1998 and fall 1998, there were no significant differences between seasons in the Ridge and Valley.

Within the Allegheny Plateau, lichen use was greater $(F=10.93, d f=4,50, P=0.0001)$ in summer 1998 than all seasons except fall 1997 (Table 2). Lichen use was also greater $(F=10.93$, $d f=4,50, P=0.0001)$ in fall 1997 than winter 1998 or fall 1998 in the Allegheny Plateau. There were no differences in lichen use among seasons within the Ridge and Valley.

Green vegetation was an important part of the diet in all seasons in both provinces (Table 2). Green vegetation was more prominent $(F=3.95, d f=4,50, P=0.0073)$ in Ridge and Valley woodrat diets in fall 1997, fall 1998, and summer 1998, whereas woodrats in the Allegheny Plateau used more $(F=8.3, d f=4,50, P=0.0001)$ green vegetation in winter 1998. Woodrats used more $(F=8.3, d f=4$, $50, P=0.0001$ ) green vegetation in the Allegheny Plateau during the winter of 1998 and summer 1998 than any other seasons. In the Ridge and Valley, green vegetation was used more frequently $(F=3.95$, $d f=4,50, P=0.0073)$ in fall 1997 than spring 1998.

Accounting for differences between provinces, woodrats ate more $(F=4.80, d f=4,50$, $P=0.0023$ ) insects in summer 1998 and fall 1998 than all other seasons (Table 2). We saw no differences in the amount of soft mast or other seeds consumed among seasons in either province. Additionally, there were no differences in total food item or species diversity measures among seasons, although, in the Ridge and Valley, species richness was higher $(F=3.44, d f=4,50, P=0.0146)$ in winter 1998 than summer 1998. 


\section{$\operatorname{Sex}$}

Male and female woodrats utilized similar foods, with few significant differences (Appendix C, D). Hard mast, soft mast, fungi, lichens, other seeds, and insects were used equally between sexes within seasons and provinces (Table 3). Accounting for differences between seasons and provinces, female woodrats used more $(F=4.57, d f=1,55, P=0.0037)$ green vegetation than males. Female woodrats had a higher ( $F=5.02, d f=1,50, P=0.034$ ) total food item richness than males in fall 1997, whereas richness was higher $(F=6.53, d f=1,50, P=0.0193)$ for males in summer 1998. Female woodrats also had higher $(F=6.83, d f=4,50, P=0.0001)$ total food item richness values in fall 1997 than fall 1998 and summer 1998, winter 1997 was higher than summer 1998, and spring 1998 was higher than summer 1998. Similarly, species richness was higher $(F=5.95, d f=1,50, P=0.0225)$ for female woodrats during fall 1997 but males had higher $(F=6.86, d f=1,50, P=0.0169)$ species richness values during summer 1998. There were no differences in total food item richness, species richness, or species diversity among seasons for males.

\section{DISCUSSION}

The Allegheny woodrat is a generalist herbivore that relies on cached food during portions of the year when other foods are rare or unavailable. Items that are cached depend on several factors such as availability, nutrient or energy content (Post 1993), and perishability (Reichman 1988). Similar to other species that exhibit caching behavior, Allegheny woodrats are faced with both long- and shortterm foraging decisions (Katz 1974, Pyke et al. 1977, Craig et al. 1979). According to optimal foraging theory (Reichman and Fay 1983), in seasons of high food resource abundance, woodrats would be expected to have lower total food item richness and diversity values than when relying on cached foods. When foraging for the short term (when food resources are abundant), animal species that cache should consume only food items that are highly preferred and would fulfill daily nutritional and energy requirements. This prevents those resources from being acquired by other individuals (Reichman and Fay 1983). When relying on cached foods, animals would be expected to consume a more diverse diet to ensure they have access to high quality food items at the end of the cache 
dependent period (Reichman and Fay 1983). Observed food habits of the Allegheny woodrat appeared to follow the predicted patterns of optimal foraging strategies. Species richness values were significantly higher in winter 1998 when woodrats were relying on cached food items.

The availability of high energy food items such as hard mast, even in times of low resource availability is crucial (Bolles 1983). The central Appalachian region experienced almost complete hard mast failure during fall 1997 (Pack 1997), while fall 1998 had an above average hard mast crop (Pack 1998). In the Allegheny Plateau, use of hard mast was higher in fall 1998 than spring, summer or winter 1998. Although, there were no significant differences, similar trends could be seen in the Ridge and Valley. Woodrats consumed the most hard mast in the late summer and throughout the fall, however, hard mast was consumed in every season regardless of abundance. High hard mast consumption in summer 1998 likely was due to an early acorn drop in August (probably due to drought conditions), which was included in summer samples. However, woodrats are capable of climbing trees (Risch and Brady 1996) and may have eaten unripe acorns as early as July.

Females had significantly higher species and total food item richness values than males during fall 1997 when caching foods for winter. Male woodrats of many species have larger home ranges than females and frequently make long distance movements (Goertz 1970, Cranford 1977, Lynch et al. 1994, Conditt and Ribble 1997, Vaughan and Schwarts 1980, Topping and Millar 1996, Castleberry in prep.). Therefore, male woodrats would be expected to encounter a higher number of preferred food items while females are restricted to the food items they encounter around the colony site. Conversely, males had higher total food item and species richness values in summer 1998. Males travel farther from the colony site, and would have more opportunities to encounter preferred food items while females are restricted to areas around the colony site. Preferred food items near the colony site would be consumed by both males and females as they were encountered, therefore lowering the abundance of food items females encounter.

Fungi, another high quality food item, was present in the diet in high amounts $(\geq 9.7 \%$ of the total diet) in every season in the Allegheny Plateau. Forest communities dominated by trees with ectomycorrihizal associations like Fagaceae, or Betulaceae, such as in the Allegheny Plateau, produce a 
greater abundance of relatively large, fleshy mushrooms and hypogeous fungi than many other forest types (Trappe 1962). Additionally, the mesic conditions found in the Allegheny Plateau facilitate mushroom growth. Compared to nut kernels (eg. pine mast, beechnuts, chestnuts, walnuts (Juglans nigra), and hickory nuts), dried mushrooms are rich in protein, carbohydrates, and minerals (Short and Epps 1976, Fogel and Trappe 1978). Additionally, dried fungi preserve well, making them perfect for caching. The effect of poor mast crops, traditionally considered a key food item in many small mammal diets in the Appalachians, may be moderated in years with a large mushroom crop (Baumgartner 1939, Brown and Yeager 1945, Lampio 1967, Ognev 1940, Rajala and Lampio 1963, Stienecker and Browning 1970, Uhlig 1955, Fogel and Trappe 1978).

Green vegetation was used in high amounts ( $\geq 18 \%$ of the total diet) in all seasons and provinces. Although we saw differences in use among seasons for both provinces, total food item and species richness (in the diet) was highest for green vegetation during the winter and spring when woodrats rely primarily on cached foods. Both amounts and richness of green vegetation consumed were lower during spring and summer when food availability was highest. Green vegetation also appears to be an important buffer food in the Ridge and Valley when mast availability is low.

Woodrat diets often were dominated by food items such as fungi, soft mast, greenbrier and blackberry leaves, and lichens. Several studies suggest that generalists can assess the nutrient value of foods and select a diet that most readily meets nutritional needs (Lindloff et al. 1974, Glander 1981, Eschelman and Jenkins 1989, Post 1993). In the more xeric Ridge and Valley, we observed that fungi was available for a shorter period of time and was less abundant than in the Allegheny Plateau.

Because fungi was only available during spring in the Ridge and Valley, woodrats consumed more fungi and fewer other items, lowering richness and diversity values.

Use of lichens was higher in the Allegheny Plateau than the Ridge and Valley. Allegheny woodrats in the Ridge and Valley only consumed small amounts of lichen in summer and fall 1998. During the growing season (May-August), lichens were an important food in the Allegheny Plateau and may be important in buffering the effects of poor mast production. 
Many soft mast producing species are high quality food items. Fleshy fruits are similar to acorns in nutrient and digestibility values (Short and Epps 1976). Soft mast use was highest during spring and summer when other food items were abundant. Although use of soft mast was high in both provinces, use of soft mast was higher in the Allegheny Plateau than the Ridge and Valley for all seasons combined. For both natural and silvicultural reasons (Barrett 1995), our sites in the Allegheny Plateau had a higher abundance of black cherry and fire cherry (P. pensylvanica) (S. B. Castleberry, in prep.). Black cherry predominates on mesic, good and excellent sites in the Allegheny Plateau, and regeneration of high densities of cherry are common after disturbance (Smith 1986, Hicks 1998). Fire cherry is an early successional species that commonly occurs in clearcuts and along roads on the WWERF. Additionally, the high number of early successional sites within our study area in the Allegheny Plateau would be favorable for the growth of soft mast species such as greenbrier, blackberry, blueberry, and mountain holly (Ilex ambigua).

Use of soft mast and insect material may have been underestimated in diets due to high rates of digestion. Soft mast, such as greenbrier fruits, blackberries, blueberries, and mountain holly, was available in large quantities (S. B. Castleberry, West Virginia University, pers. comm.) and piles of cherry seeds were found around colony sites in the Allegheny Plateau. The importance of soft-bodied insects has been documented for several small mammals species, such as deer mice (Peromyscus maniculatus), white-footed mice (P. leucopus), red-backed voles (Clethrionomys gapperi), bog lemmings (Synaptomys cooperi), woodland jumping mice (Napaeozapus insignis), and squirrels (Sciurus carolinensis, S. niger, Glaucomys sabrinus) (Alcoze and Zimmerman 1973, Whitaker 1966, Houtcooper 1978, Hamilton 1941, Maser et al. 1985, Nixon et al. 1968). Soft-bodied insects are often completely digested and hence undetectable in the feces (T. C. Carter, Southern Illinois University, pers. comm.).

Most woodrat species are generalist herbivores that are capable of adapting their feeding habits to local conditions and available food resources (Rainey 1956). Allegheny woodrats differ from other woodrat species because they are habitat specialists (Newcombe 1930, Poole, 1940). Because Allegheny woodrats are reliant on rocky habitats, they may be more severely affected by habitat change 
than other similar woodrat species. Allegheny woodrats cannot easily disperse and re-establish new home ranges without relocating to other rock outcrops. Because of this, habitat changes could cause localized extirpations if disturbances are severe, where similar disturbances in other woodrat species may cause little effect. Research is needed to examine the long-term effects of these changes on survivorship, overall condition, and reproductive success of this species.

\section{MANAGEMENT IMPLICATIONS}

Our data suggest the following foods as representative of the seasonal selectivity of Allegheny woodrats in the Central Appalachians: winter-wood/shield fern, blackberry leaves, blueberry leaves, fungi, and hemlock; spring — fungi, buds, blackberry leaves, holly fruit, and greenbrier fruit; summer — fungi, lichen, acorn, blueberry leaves, and holly/blueberry fruit; fall-acorns, fungi, wood/shield fern, greenbrier and blackberry leaves, and Christmas fern. Similar sized rodents consume approximately their own weight in food per week (Uhlig 1955). Therefore, during the cache dependent period (mid November through mid March), each woodrat may require $37.5-55 \mathrm{~kg}$ of food. Although other foods are used during this time, our data show there is a strong dependence on hard mast and fungi during the winter months.

Average seed crops for central hardwood oak stands may reach $322 \mathrm{~kg}$ of acorns per acre (Goodrum et al. 1971). Unlike other mast species, the period between good acorn crops cannot be estimated. There are no similar production estimates for other mast species, however, their presence as an alternate food source is critical in years of poor acorn production. Black oaks (scarlet, northern red, and black) are more dependable mast producers than white or chestnut oak and therefore should be promoted when possible (Nixon et al. 1968). Additionally, mast from buffer species is more common and diverse than traditional mast producers such as oaks and hickories (Edwards et al. 1993). Traditional mast is usually only available to wildlife in the late summer and fall while other mast species produce mast throughout the year. During the summer, soft mast species such as black cherry, blackberries, blueberries, are among the most highly used food items by woodrats. 
To maximize the benefits to Allegheny woodrats and to minimize variation in mast availability, we suggest promoting both traditional mast species (such as oak, cherry, and beech) as well as nontraditional mast species (such as grape, blueberry, maple, and greenbrier). This allows buffer species to provide mast in seasons when traditional mast is not available (Edwards et al. 1993). During years of poor traditional mast production, buffer species will compensate and provide a variety of available foods.

\section{LITERATURE CITED}

AlCOZE, T. M., AND E. G. ZimMERMAN. 1973. Food habits and dietary overlap of two heteromyid rodents from the mesquite plains of Texas. J. Mammal. 54:900-908.

BALCOM, B. J., AND R. H. YAHNER. 1996. Microhabitat and landscape characteristics associated with the threatened Allegheny Woodrat. Cons. Biol. 10:515-525.

BARRETT, J. W. 1995. "The Southern Appalachian Hardwood Region” in Regional Siviculture of the United States. John Wiley and Sons, Inc. New York. 643 pp.

Baumgartner, L. L. 1939. Food of the fox squirrel in Ohio. Ohio Wildl. Res. Sta. Release 108. $7 \mathrm{pp}$.

Baumgartner, L. L., AND A. C. MARTin. 1939. Plant histology as an aid in squirrel food-habits studies. J. Wildl. Manage. 3:266-268.

BEANS, B. E. 1992. Without a trace: The puzzling demise of the Allegheny woodrat. Audubon. 92:32-34.

Bolles, R. C. 1983. A “mixed” model of taste preference. Pp. 65-82 in R. L. Mellegren, ed., Animals cognitions and behavior. North Holland Publishing Co., New York, 513pp.

BRAun, E. L. 1950. Deciduous forest of Eastern North America. Blakiston, Co., Philadelphia, PA. $596 \mathrm{pp}$.

Brown, L. G., AND L. E. YEAGER. 1945. Fox squirrels and grey squirrels in Illinois. Ill. Nat. Hist. Surv. Bull. 23:449-536.

CASTLEBerRy, S. B. In prep. Conservation of the Allegheny woodrat in the central Appalachians. Ph.D. Dissertation, West Virginia University, Morgantown. 
CONDITT, S. A., AND D. O. RiBBLE. 1997. Social organization of Neotoma micropus, the southern plains woodrat. Am. Mildl. Nat. 137:290-297.

CRAIG, R. B., D. L. DEANGELIS, AND K. R. DiXON. 1979. Long- and short-term dynamic optimization models with application to the feeding strategy of the loggerhead shrike. Am. Nat. 113:31-51.

CRANFORD, J. A. 1977. Home range and habitat utilization by Neotoma fuscipes as determined by radiotelemetry. J. Mammal. 58:165-172.

DAvitT, B., AND J. R. Nelson. 1980. A Method of Preparing Plant Epidermal Tissue for Use in Fecal Analysis. College of Agriculture Research Center, Washington State University Circular 0628.

DunN, J., J. HALl, AND T. WiLKInSON. 1989. Report of woodrat survey trapping. Appendix 2 and 3. Woodrat Subcommittee, Pennsylvania Game Commission, Harrisburg.

EDWARDS, J. W., D. C. GUYNN, JR., AND S. C. LOEB. 1993. Seasonal mast availability for wildlife in the Piedmont Region of Georgia. USDA For. Serv. Res. Pap. SE-287.

ESHELMAN, B. D., AND S. H. JENKINS. 1989. Food selection by Belding's ground squirrels in relation to plant nutritional features. J. Mammal., 70:846-852.

FEnneman, N. M. 1938. Physiography of the Eastern United States. McGraw-Hil, New York. 714pp.

FITCH, H. S. AND D. G. RAINEY. 1956. Ecological observations on the woodrat, Neotoma floridana. Univ. Kansas Publ.., Mus. Nat. Hist. 8:499-533.

FOGEL, R. D., J. M. TRAPPE. 1978. Fungus consumption (mycophagy) by small mammals. Northwest Sci. $52: 1-31$.

GlANDER, K. E. 1981. Feeding patterns in mantled howler monkeys. Pp. 231-257, in A. C. Kamil and T. C. Sargent, eds. Foraging Behavior: ecological, ethological, and psychological approaches Garland STPM Press, New York. 534 pp.

GoertZ, J. W. 1970. An ecological study of Neotoma floridana in Oklahoma. J. Mammal. 51:94104. 
GOODRUM, P. D., V. H. REID, AND C. E. BOYD. 1971. Acorn yields, characteristics, and management criteria of oaks for wildlife. J. Wildl. Mange. 35:520-532.

HALL, E. R. 1981. The mammals of North America. 2nd Ed. John Wiley and Sons, New York.

HALl, J. S. 1985. Threatened eastern woodrat Neotoma floridana (Ord) Family Cricetidae, Order Rodentia. Special Publication Carnegie Museum of Natural History. 11:362-365. . 1988. Survey of the woodrat in Pennsylvania. Final Report. Pennsylvania Game Commission, Harrisburg, Pennsylvania.

HAmilton, W. J., JR. 1941. The food of small forest mammals in the Eastern United States. J. Mammal. 21:250-263.

HASsinger, J., C. ButChKOSKI, D. DiEFENBACH. 1996. Fragmentation effects on the occupancy of forested Allegheny woodrat (Neotoma magister) colony areas. Unpublished Report.

HICKS, A. 1989. What happened to the Allegheny woodrat? Pp. 34-38 in The conservationist (March-April), New York State Dept. of Environmental Conservation, Albany.

HICKS, R. R., JR. 1998. Ecology and Management of Central Hardwood Forests. John Wiley and Sons, Inc. New York, NY.

HoleCHEK, J. L., AND B. D. GROSS. 1982. Evaluation of Different Calculation Procedures for Microhistological Analysis. J. Range Manage. 35:721-723.

HoutCOOPER, W. C. 1978. Food habits of rodents in a cultivated ecosystem. J. Mammal. 59:427430.

HuNTLEY, J. C. 1990. Importance and management of mast species other than oaks. in McGee, C.E., ed. Proceedings of the workshop: Southern Appalachian mast management; 1989 August 14-16; Knoxville, TN. U.S.D.A., For. Serv. Southern Region, Cherokee Nat. For: 74-82.

KATZ, P. L. 1974. A long-term approach to foraging optimization. Am. Nat. 108:758-782.

LAMPIO, T. 1967. Sex ratios and the factors contributing to them in the squirrel, Sciurus vulagris, in Finland. Riistat. Julk. 29:1-69. 
LINDLOFF, B., E. LINDSTROM, AND A. PEHRSON. 1974. Nutrient content in relation to food preferred by mountain hare. J. Wildl. Manage. 38:875-879.

LYNCH, M. F., A. L. FESNOCK, AND D. VAN VUREN. 1994. Home range and social structure of the dusky-footed woodrat (Neotoma fuscipes). Northwestern Nat. 75:73-75.

MagurRan, A. E. 1988. Ecological diversity and its measurement. Princeton Univ. Press. Princeton, NJ. $179 \mathrm{pp}$.

MASER, Z., C. MASER, AND J. M. TRAPPE. 1985. Food habits of the northern flying squirrel (Glaucomys sabrinus) in Oregon. 63:1084-1088.

MCGOWAN, E. AND A. HICKS. 1996. Baylisascaris procyonis: the probable cause of extirpation of the Allegheny woodrat in New York State. page 4 in Abstracts of the 1996 Allegheny Woodrat Recovery Group Meeting, Ferrum College, Ferrum, Virginia.

MCINTIRE, P. W., AND A. B. CAREY. 1989. A Microhistological Technique for Analysis of Food Habits of Mycophagous Rodents. U.S.D.A. For. Serv. Pacific Northwest Res. Stn. Res. Pap. 404.

MENGAK, M. T. 1996. Status and distribution of woodrat metapopulations in Virginia. pp 2-4 in Abstracts of the 1996 Allegheny Woodrat Recovery Group Meeting., Ferrum College, Ferrum, Virginia.

NAWrot, J. R. AND W. D. Klimstra. 1976. Present and past distribution of the endangered southern Illinois woodrat (Neotoma floridana illioensis). Chicago Academy Sci. Nat. Hist. Misc. 196:1-12.

NewCOMBE, C. L. 1930. An ecological study of the Allegheny wood rat. J. Mammal. 11:204-211.

NiXon, C. M., D. M. WorLeY, AND M. W. MCClain. 1968. Food habits of squirrels in southeast Ohio. J. Wildl. Manage. 32:294-305.

ORGNEV, S. I. 1940-1950. Mammals of the USSR and adjacent countries. Vols. IV, V, VI, and VII. Trans. By Jean Salkind. Smithsonian Ins. and NSF, Washington, DC.

PACK, J. C. 1997. 1997 Mast survey and West Virginia Hunting Outlook. West Virginia Department of Natural Resources, unpublished report. 
1998. 1998 Mast survey and West Virginia Hunting Outlook. West Virginia Department of Natural Resources, unpublished report.

PEARSON, P. G. 1952. Observations concerning the life history and ecology of the woodrat, Neotoma floridana floridana (Ord). J. Mammal. 33:459-463.

POOLE, E. L. 1936. Notes on the young of the Allegheny wood rat. J. Mammal. 17:22-26. , 1940. A life history sketch of the Allegheny woodrat. J. Mammal. 21:249-270.

PosT, D. M. 1993. Detection of differences in nutrient concentrations by eastern woodrats (Neotoma floridana). J. Mammal. 74:493-497.

PyKe, G., H. R. PUlliAM, AND E. L. ChARNOV. 1977. Optimal foraging: a selective review of theory and tests. Q. Rev. Biol. 52:137-154.

RAINEY, DG 1956. Eastern woodrat: Neotoma floridana: life history and ecology. Univ. Kansas Publ., Mus. Nat. Hist. 8:369-375.

RAJALA, P., AND T. LAMPIO. 1963. The food of the squirrel (Sciurus vulgaris) in Finland in 19451961. Soumen Riisata, Helsinki. 16:155-185.

REICHMAN, O. J. 1988. Caching behavior of eastern woodrats, Neotoma floridana, in relation to food perishability. Anim. Behav. 36:1525-1532.

, AND P. FAY. 1983. Comparison of the diets of a caching and noncaching rodent. Am. Nat.122:576-581.

RISCH, T. S., AND M. J. BRADY. 1996. Trap Height and Capture Success of Arboreal Small Mammals: Evidence from Southern Flying Squirrels (Glaucomys volans). Am. Midl. Nat. 136:346-351.

SAS InSTITUTE. 1990. SAS user's guide. Version 6. SAS Institute, Cary, North Carolina, USA.

SHANNON, C. E., AND W. WEAVER. 1963. The mathematical theory of communication. Univ. Illinois Press, Urbabana, 117 pp.

SHORT, H. L., AND E. A. EPPS., JR. 1976. Nutrient quality and digestibility of seeds and fruits from southern forests. J. Wildl. Manage. 40:283-289. 
SMITH, D. M. 1986. The practice of silviculture. Eighth edition. Wiley and Sons, New York, New York, USA. 257 pp.

SOKAL, R. R., AND F. J. ROHLF. 1995. Biometry. Third edition. W. H. Freeman and Co., New York, New York, USA. 887 pp.

SPARKS, D. R., AND J. C. MALECHEK. 1968. Estimating percentage dry weights in diets using a microscopic technique. J. Range. Manage. 21:264-265.

SteEl, G. W., AND J. H. TORRIE. 1980. Principles and procedures of statistics. Second edition. McGraw Hill, New York. USA.

STIENECKER, W., AND B. M. BROWNING. 1970. Food habits of the western gray squirrel. Calif. Fish and Game. 56:36-48.

STIHLER, C. AND J. WALlaCE. 1996. Woodrat studies in West Virginia. p.2., in Abstracts of the 1996 Allegheny Woodrat Recovery Group Meeting., Ferrum College, Ferrum, Virginia.

Strausbaugh, P. D., And E. L. CORE. 1977. The Flora of West Virginia. Fourth printing. Seneca Books, Inc., Morgantown, West Virginia. USA.

TOPPING, M. G., AND J. S. MiLlaR. 1996. Home range size of busy-tailed woodrats, Neotoma cinerea, in southwestern Alberta. The Canadian Field Nat. 110:350-353.

TraPPE, J. M. 1962. Fungus associates of ectotropic mycorrhizae. Bot. Rev. 28:538-606.

Uhlig, H. C. 1955. The Gray Squirrel: It's Life History, Ecology, and Population Characteristics in West Virginia. W. Va. Conserv. Comm. 175 pp.

VAUGHAN, T. A., AND S. T. SChWARTZ. 1980. Behavioral ecology of an insular woodrat. J. Mammal. 61:205-218.

WhitAKer, J. O., JR. 1966. Food of Mus Musculus, Peromyscus maniculatus bairdi and Peromyscus leucopus in Vigo County, Indiana. J. Mammal. 47:473-486.

WILEY, R. W. 1980. Neotoma floridana. Mammalian Species, No. 139.

WYDEVEN, P. R., AND R. B. DAHLGREN. 1982. A comparison of prairie dog stomach contents and feces using a microhistological technique. J. Wildl. Manage. 46:1104-1108. 
Table 1. Common food items of Allegheny woodrats from the Ridge and Valley physiographic province of West Virginia and Virginia and Allegheny Plateau physiographic province of West Virginia from November 1997 through December 1998. Expressed as percent of the total diet \pm SE. Taxonomy follows Strausbaugh and Core 1977.

\begin{tabular}{|c|c|c|c|}
\hline Variable & Ridge and Valley & Allegheny Plateau & Combined \\
\hline \multicolumn{4}{|l|}{ Food item } \\
\hline $\begin{array}{l}\text { blackberry leaves } \\
\text { (Rubus spp.) }\end{array}$ & $11.9 \% \pm 2.0$ & $3.2 \% \pm 0.5$ & $7.1 \% \pm 1.0$ \\
\hline fungi & $4.5 \% \pm 1.3$ & $17.3 \% \pm 2.5$ & $12.2 \% \pm 1.7$ \\
\hline $\begin{array}{l}\text { greenbrier leaves } \\
\text { (Smilax spp.) }\end{array}$ & $5.3 \% \pm 1.1$ & $0.6 \% \pm 0.3$ & $2.7 \% \pm 0.5$ \\
\hline acorns (Quercus spp.) & $3.6 \% \pm 1.6$ & $7.9 \% \pm 2.3 \%$ & $6.0 \% \pm 1.5$ \\
\hline oak leaves (Quercus spp.) & $5.0 \% \pm 0.7$ & $0.4 \% \pm 0.1$ & $1.3 \% \pm 0.3$ \\
\hline $\begin{array}{l}\text { shield and wood ferns } \\
\text { (Dryopteris spp.) }\end{array}$ & $4.4 \% \pm 1.7$ & $7.0 \% \pm 1.9$ & $5.9 \% \pm 1.3$ \\
\hline 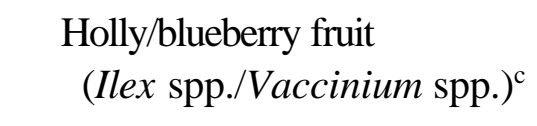 & $0.0 \% \pm 0.0$ & $7.3 \% \pm 1.6$ & $3.7 \% \pm 0.8$ \\
\hline lichen & $0.1 \% \pm 0.1$ & $6.5 \% \pm 1.6$ & $3.7 \% \pm 0.9$ \\
\hline Species richness $^{\mathrm{a}}$ & $9.8 \pm 0.4$ & $10.1 \pm 0.4$ & $10.0 \pm 0.3$ \\
\hline Species diversity ${ }^{\mathrm{a}}$ & $1.8 \pm 0.1$ & $1.8 \pm 0.1$ & $1.8 \pm 0.1$ \\
\hline Total richness $^{\mathrm{b}}$ & $10.7 \pm 0.4$ & $10.6 \pm 0.4$ & $10.7 \pm 0.3$ \\
\hline Total diversity ${ }^{b}$ & $1.9 \pm 0.6$ & $1.8 \pm 0.1$ & $1.9 \pm 0.1$ \\
\hline
\end{tabular}

${ }^{\mathrm{a}}$ Species richness and diversity were calculated with all species that occurred in the diet.

${ }^{b}$ Total richness and diversity were calculated with all possible food items found in the diet.

'Due to difficulty in distinguishing between similar cell characteristics, some genera have bee pooled. 
Table 2. Average percent consumed of major food categories eaten by Allegheny woodrats by season in the Ridge and Valley (RV) and Allegheny Plateau (AP) physiographic provinces of West Virginia and Virginia. 1997-1998. Expressed as percent of the total diet \pm SE.

\begin{tabular}{|c|c|c|c|c|c|c|c|c|c|c|}
\hline & \multicolumn{2}{|c|}{$\underline{\text { Fall } 1997}$} & \multicolumn{2}{|c|}{$\underline{\text { Winter } 1998}$} & \multicolumn{2}{|c|}{ Spring 1998} & \multicolumn{2}{|c|}{$\underline{\text { Summer } 1998}$} & \multicolumn{2}{|c|}{$\underline{\text { Fall } 1998}$} \\
\hline & $\begin{array}{c}\mathrm{RV} \\
(n=11)\end{array}$ & $\begin{array}{c}\mathrm{AP} \\
(n=15)\end{array}$ & $\begin{array}{c}\mathrm{RV} \\
(n=13)\end{array}$ & $\begin{array}{c}\text { AP } \\
(n=12)\end{array}$ & $\begin{array}{c}\mathrm{RV} \\
(n=14)\end{array}$ & $\begin{array}{c}\mathrm{AP} \\
(n=13)\end{array}$ & $\begin{array}{c}\mathrm{RV} \\
(n=8)\end{array}$ & $\begin{array}{c}\mathrm{AP} \\
(n=13)\end{array}$ & $\begin{array}{c}\mathrm{RV} \\
(n=9)\end{array}$ & $\begin{array}{c}\mathrm{AP} \\
(n=15)\end{array}$ \\
\hline \multicolumn{11}{|l|}{ Food group } \\
\hline Fungi & $0.4 \pm 0.4$ & $27.4 \pm 6.2$ & $1.1 \pm 0.8$ & $10.8 \pm 4.5$ & $12.9 \pm 3.9$ & $9.7 \pm 3.4$ & $3.6 \pm 1.5$ & $20.1 \pm 5.6$ & $5.3 \pm 5.3$ & $16.5 \pm 6.3$ \\
\hline Hard mast & $3.8 \pm 1.7$ & $11.5 \pm 4.1$ & $2.0 \pm 1.6$ & $2.9 \pm 1.2$ & $7.5 \pm 3.9$ & $4.4 \pm 1.1$ & $22.9 \pm 12.3$ & $10.2 \pm 6.4$ & $21.9 \pm 9.5$ & $29.7 \pm 7.5$ \\
\hline Soft mast & $7.3 \pm 2.8$ & $20.0 \pm 5.5$ & $4.1 \pm 1.3$ & $16.4 \pm 6.1$ & $12.4 \pm 6.0$ & $23.5 \pm 4.9$ & $14.9 \pm 11.3$ & $25.1 \pm 8.9$ & $1.8 \pm 1.8$ & $9.1 \pm 2.4$ \\
\hline Fern & $2.5 \pm 1.7$ & $11.1 \pm 4.9$ & $12.7 \pm 5.7$ & $11.1 \pm 5.2$ & $4.2 \pm 2.6$ & $2.5 \pm 1.4$ & $0.0 \pm 0.0$ & $0.7 \pm 0.4$ & $3.1 \pm 1.9$ & $15.0 \pm 6.2$ \\
\hline Other seeds & $5.3 \pm 2.2$ & $1.9 \pm 1.1$ & $2.9 \pm 1.6$ & $1.5 \pm 1.0$ & $1.3 \pm 1.0$ & $2.6 \pm 1.1$ & $0.0 \pm 0.0$ & $0.0 \pm 0.0$ & $5.3 \pm 5.3$ & $1.2 \pm 1.2$ \\
\hline Lichens & $0.0 \pm 0.0$ & $4.5 \pm 1.2$ & $0.0 \pm 0.0$ & $1.0 \pm 0.6$ & $0.0 \pm 0.0$ & $4.6 \pm 2.2$ & $0.5 \pm 0.5$ & $22.0 \pm 6.2$ & $0.3 \pm 0.3$ & $1.2 \pm 0.8$ \\
\hline Insect & $0.2 \pm 0.2$ & $0.0 \pm 0.0$ & $0.0 \pm 0.0$ & $0.4 \pm 0.4$ & $0.6 \pm 0.4$ & $0.0 \pm 0.0$ & $5.2 \pm 2.6$ & $1.3 \pm 0.5$ & $3.1 \pm 1.3$ & $3.0 \pm 0.9$ \\
\hline Buds & $0.0 \pm 0.0$ & $0.0 \pm 0.0$ & $0.0 \pm 0.0$ & $0.0 \pm 0.0$ & $18.1 \pm 7.3$ & $0.0 \pm 0.0$ & $3.0 \pm 2.5$ & $0.0 \pm 0.0$ & $0.0 \pm 0.0$ & $0.0 \pm 0.0$ \\
\hline $\begin{array}{c}\text { Green } \\
\text { vegetation }\end{array}$ & $79.0 \pm 4.3$ & $21.4 \pm 5.1$ & $73.2 \pm 5.2$ & $52.4 \pm 8.2$ & $45.1 \pm 6.3$ & $50.4 \pm 6.6$ & $51.5 \pm 15.0$ & $20.1 \pm 5.2$ & $64.0 \pm 14.7$ & $18.1 \pm 4.0$ \\
\hline $\begin{array}{l}\text { Species } \\
\text { richness }^{\text {a }}\end{array}$ & $10.8 \pm 0.8$ & $11.7 \pm 0.7$ & $11.5 \pm 0.6$ & $9.1 \pm 0.8$ & $9.4 \pm 1.1$ & $11.7 \pm 0.6$ & $7.0 \pm 1.0$ & $8.8 \pm 0.8$ & $9.3 \pm 0.7$ & $9.1 \pm 0.7$ \\
\hline Species & & & & & & & & & & \\
\hline Diversity $^{\mathrm{a}}$ & $2.0 \pm 0.1$ & $2.0 \pm 0.1$ & $2.0 \pm 0.1$ & $1.7 \pm 0.1$ & $1.7 \pm 0.2$ & $2.1 \pm 0.1$ & $1.4 \pm 0.2$ & $1.5 \pm 0.2$ & $1.8 \pm 0.1$ & $1.6 \pm 0.1$ \\
\hline Total richness $^{\mathrm{b}}$ & $11.8 \pm 0.9$ & $12.1 \pm 0.8$ & $12.6 \pm 0.5$ & $9.9 \pm 0.9$ & $10.2 \pm 1.0$ & $12.5 \pm 0.7$ & $7.6 \pm 0.9$ & $9.1 \pm 0.9$ & $10.0 \pm 0.8$ & $9.5 \pm 0.8$ \\
\hline Total diversity ${ }^{\mathrm{b}}$ & $2.1 \pm 0.1$ & $2.0 \pm 0.1$ & $2.1 \pm 0.1$ & $1.8 \pm 0.1$ & $1.9 \pm 0.1$ & $2.2 \pm 0.1$ & $1.6 \pm 0.1$ & $1.5 \pm 0.2$ & $1.8 \pm 0.1$ & $1.7 \pm 0.2$ \\
\hline
\end{tabular}

${ }^{\text {a }}$ Species richness and diversity were calculated with all species that occurred in the diet.

${ }^{\mathrm{b}}$ Total richness and diversity were calculated with all possible food items found in the diet. 
Table 3. Average percent consumed of major food categories eaten by male and female Allegheny woodrats by season in the Ridge and Valley and Allegheny Plateau physiographic provinces of West Virginia and Virginia, 1997-1998. Expressed as percent of the total diet \pm SE.

\begin{tabular}{|c|c|c|c|c|c|c|c|c|c|c|}
\hline & \multicolumn{2}{|c|}{$\underline{\text { Fall } 1997}$} & \multicolumn{2}{|c|}{$\underline{\text { Winter } 1998}$} & \multicolumn{2}{|c|}{$\underline{\text { Spring } 1998}$} & \multicolumn{2}{|c|}{$\underline{\text { Summer } 1998}$} & \multicolumn{2}{|c|}{$\underline{\text { Fall } 1998}$} \\
\hline & $\begin{array}{c}\text { Male } \\
(n=10)\end{array}$ & $\begin{array}{l}\text { Female } \\
(n=16)\end{array}$ & $\begin{array}{l}\text { Male } \\
(n=6)\end{array}$ & $\begin{array}{l}\text { Female } \\
(n=19)\end{array}$ & $\begin{array}{l}\text { Male } \\
(n=7)\end{array}$ & $\begin{array}{r}\text { Female } \\
(n=20)\end{array}$ & $\begin{array}{l}\text { Male } \\
(n=8)\end{array}$ & $\begin{array}{r}\text { Female } \\
(n=13)\end{array}$ & $\begin{array}{l}\text { Male } \\
(n=10)\end{array}$ & $\begin{array}{l}\text { Female } \\
(n=14)\end{array}$ \\
\hline \multicolumn{11}{|l|}{ Food group } \\
\hline Fungi & $24.0 \pm 7.0$ & $11.0 \pm 5.5$ & $2.4 \pm 1.2$ & $6.8 \pm 3.1$ & $8.3 \pm 2.5$ & $12.2 \pm 3.3$ & $30.3 \pm 8.0$ & $5.7 \pm 2.2$ & $14.1 \pm 8.6$ & $14.9 \pm 7.0$ \\
\hline Hard mast & $13.5 \pm 5.8$ & $5.0 \pm 1.9$ & $1.1 \pm 1.1$ & $2.9 \pm 1.2$ & $5.7 \pm 1.9$ & $5.8 \pm 2.4$ & $3.2 \pm 1.8$ & $20.8 \pm 8.8$ & $32.6 \pm 10.3$ & $23.3 \pm 7.0$ \\
\hline Soft mast & $18.4 \pm 7.3$ & $12.3 \pm 3.7$ & $14.8 \pm 11.9$ & $8.5 \pm 2.2$ & $31.9 \pm 6.4$ & $13.9 \pm 4.4$ & $21.5 \pm 13.0$ & $21.5 \pm 8.4$ & $10.3 \pm 3.4$ & $6.7 \pm 2.7$ \\
\hline Fern & $7.1 \pm 4.0$ & $7.7 \pm 4.2$ & $23.1 \pm 9.5$ & $8.4 \pm 3.8$ & $3.0 \pm 3.0$ & $3.4 \pm 1.6$ & $0.4 \pm 0.4$ & $0.5 \pm 0.3$ & $24.6 \pm 12.6$ & $7.3 \pm 4.2$ \\
\hline Other seeds & $1.7 \pm 1.0$ & $4.3 \pm 1.7$ & $0.6 \pm 0.6$ & $2.7 \pm 1.3$ & $2.7 \pm 1.7$ & $1.8 \pm 0.9$ & $0.0 \pm 0.0$ & $0.0 \pm 0.0$ & $0.0 \pm 0.0$ & $2.8 \pm 1.9$ \\
\hline Lichens & $4.1 \pm 1.3$ & $1.6 \pm 1.0$ & $0.6 \pm 0.6$ & $0.5 \pm 0.3$ & $5.7 \pm 3.9$ & $1.0 \pm 0.6$ & $12.1 \pm 5.0$ & $14.9 \pm 6.6$ & $1.3 \pm 1.1$ & $0.5 \pm 0.3$ \\
\hline Insect & $0.0 \pm 0.0$ & $0.1 \pm 0.1$ & $0.0 \pm 0.0$ & $0.3 \pm 0.3$ & $0.0 \pm 0.0$ & $0.4 \pm 0.3$ & $1.4 \pm 0.5$ & $3.7 \pm 1.7$ & $4.2 \pm 1.2$ & $2.2 \pm 0.8$ \\
\hline Buds & $0.0 \pm 0.0$ & $0.0 \pm 0.0$ & $0.0 \pm 0.0$ & $0.0 \pm 0.0$ & $10.2 \pm 7.8$ & $8.6 \pm 4.8$ & $2.5 \pm 2.5$ & $0.3 \pm 0.3$ & $0.0 \pm 0.0$ & $0.0 \pm 0.0$ \\
\hline $\begin{array}{c}\text { Green } \\
\text { vegetation }\end{array}$ & $30.8 \pm 10.7$ & $55.0 \pm 7.8$ & $55.9 \pm 11.9$ & $65.5 \pm 5.7$ & $35.9 \pm 5.9$ & $52.0 \pm 5.5$ & $28.5 \pm 10.5$ & $32.5 \pm 9.2$ & $13.3 \pm 5.1$ & $32.0 \pm 7.7$ \\
\hline $\begin{array}{l}\text { Species } \\
\text { richness }^{\text {a }}\end{array}$ & $9.9 \pm 1.0$ & $12.2 \pm 0.5$ & $10.3 \pm 1.3$ & $10.4 \pm 0.6$ & $10.6 \pm 0.9$ & $10.5 \pm 0.9$ & $10.0 \pm 1.1$ & $7.0 \pm 0.6$ & $9.0 \pm 0.8$ & $9.3 \pm 0.7$ \\
\hline $\begin{array}{l}\text { Species } \\
\text { Diversity }^{\mathrm{a}}\end{array}$ & $1.8 \pm 0.1$ & $2.1 \pm 0.1$ & $1.8 \pm 0.2$ & $2.0 \pm 0.1$ & $2.0 \pm 0.2$ & $1.9 \pm 0.1$ & $1.7 \pm 0.2$ & $1.3 \pm 0.1$ & $1.6 \pm 0.2$ & $1.8 \pm 0.1$ \\
\hline Total richness ${ }^{\mathrm{b}}$ & $10.5 \pm 1.0$ & $12.9 \pm 0.7$ & $11.0 \pm 1.2$ & $11.4 \pm 0.6$ & $11.1 \pm 0.8$ & $11.3 \pm 0.9$ & $10.4 \pm 1.1$ & $7.4 \pm 0.6$ & $9.7 \pm 0.9$ & $9.7 \pm 0.8$ \\
\hline Total diversity ${ }^{\mathrm{b}}$ & $1.8 \pm 0.1$ & $2.1 \pm 0.1$ & $1.8 \pm 0.2$ & $2.0 \pm 0.1$ & $2.0 \pm 0.1$ & $2.0 \pm 0.1$ & $1.8 \pm 0.2$ & $1.4 \pm 0.1$ & $1.7 \pm 0.2$ & $1.8 \pm 0.1$ \\
\hline
\end{tabular}

${ }^{a}$ Species richness and diversity were calculated with all species that occurred in the diet.

$\mathrm{b}$ Total richness and diversity were calculated with all possible food items found in the diet. 


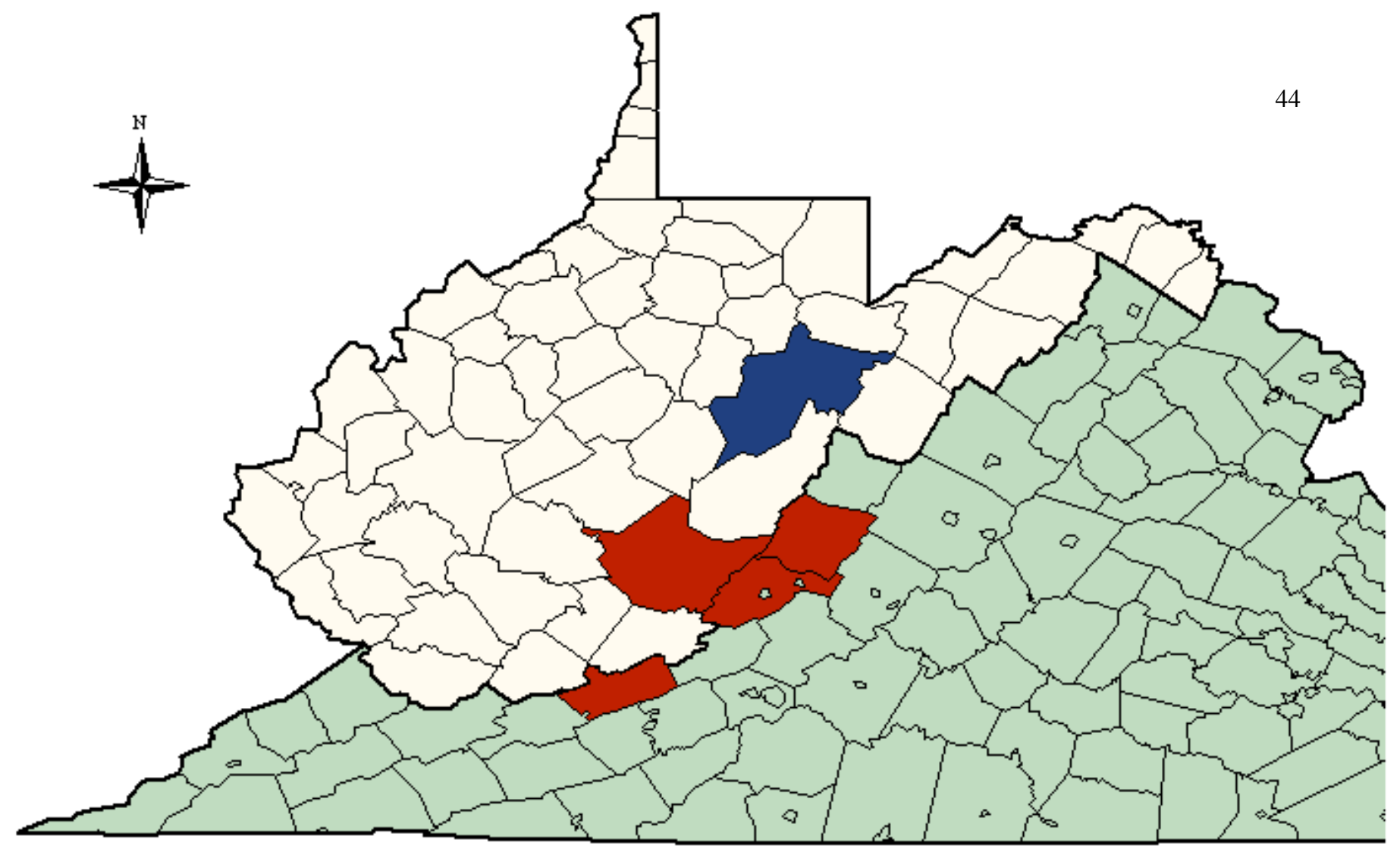

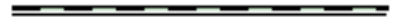

$100 \mathrm{~km}$
Legend

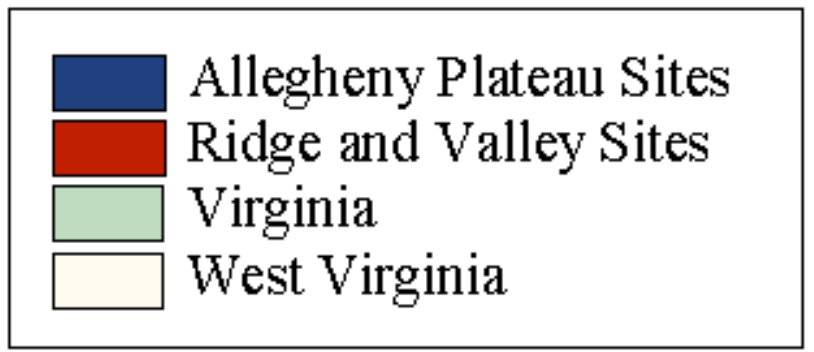

Figure 1. Fecal sample collection sites in the Ridge and Valley and Allegheny Plateau physiographic provinces of West Virginia and Virginia, 1997-1998. 
CHAPTER 3

THE EFFECTS OF FOREST MANAGEMENT ON THE FOOD HABITS OF THE ALLEGHENY WOODRAT IN WEST VIRGINIA

Castleberry, N.L., P.B. Wood, W.M. Ford, and S.B. Castleberry. To be submitted to the Proceedings of the Southeastern Fish and Wildlife Association. 
Recent regional declines in Allegheny woodrat (Neotoma magister) populations suggest a better understanding of the basic ecology of this species is needed for proper management. Because current forest management practices within its core range may be affecting available food resources, resource managers are increasingly in need of information regarding management effects. We described the food habits of the Allegheny woodrat from clearcut, diameter-limit, and intact forests in the Allegheny mountains of east-central West Virginia using microhistological techniques. Fecal material was collected from woodrats at colonies located adjacent to or within 3 diameter-limit harvests, 4 clearcuts, and 4 uncut sites between November 1997 and December 1998. Total food item and species richness and diversity measures were also calculated. We examined differences in use of hard mast, other seeds, soft mast, fungi, lichens, green vegetation, buds, and animal matter among harvest types. We saw no significant differences in use among treatment types for any of the variables measured. Additionally, there were no differences in richness or diversity measures between harvest types, although all values were higher at undisturbed sites than either cut treatment. Our data suggest timber management can occur within close proximity to woodrat colonies without seriously influencing food availability, as long as a forested buffer is left between the cut and the colony site. Buffers should contain a variety of hard and soft mast producing species to provide a range of quality food items.

Key words: Allegheny woodrat, Central Appalachians, fecal analysis, food habits, fungi, mast, microhistology, Neotoma magister, timber management. 
The Allegheny woodrat (Neotoma magister) is a generalist rodent herbivore formerly distributed from the Catskill Mountains of southeastern New York down the Appalachian spine to the Tennessee River in Alabama and Tennessee (Newcombe 1930, Poole 1940, Wiley 1980, Hall 1981). The species occupies rocky habitats throughout the Appalachian mountains and animals from an individual rock outcrop form what is referred to as a colony. Currently, the species is listed as threatened, endangered, or as a species of special concern in every state in which it occurs due to apparent population declines in the northern and western extents of the distributional range. In eastern Pennsylvania, New Jersey, Ohio, and Indiana, woodrats are absent from many historic colony sites and the species is now extirpated in New York (Hall 1988, Hicks 1989, Beans 1992). Populations within the core of the range appear to be stable, although actual population status is not known (Mengak 1996, Stihler and Wallace 1996).

Allegheny woodrats are considered generalist herbivores that consume a variety of fruits, nuts, and green vegetation (Rainey 1956, Post 1993, N. L. Castleberry, unpublished data). Hard mast and fungi are consumed extensively and make up the largest portion of the diet when available (Parks 1922, Newcombe 1930, Poole 1940, Linsdale and Tevis 1951, Finley 1958). Woodrats have been reported to feed on animal matter, chiefly insects, though it has never been reported as a dominant food item (Poole 1940, Vorhies and Taylor 1940, Linsdale and Tevis 1951, Murphy 1952, Fitch and Rainey 1956, Horne 1996). While foraging, woodrats collect and cache large amounts of hard mast, fungi, and green vegetation from September or October until the onset of winter. Although limited foraging occurs, woodrats rely on cached food items during the winter months, presumably to avoid being left with poor quality foods before the cache can be restocked (Post 1993). 
Multiple reasons are suspected as causes for Allegheny woodrat decline, including several proximal factors affecting the availability of food resources. These include reduction of annual hard mast crops resulting from chestnut blight (Cryphonectria parasitica) and gypsy moth (Lymantria dispar) infestations of oak (Quercus spp.) stands (Hall 1988), changes in plant species composition due to increased deer hervbivory, and short-rotation forest management. Each of these factors can work singularly, however, multiple factors may be operating in a synergistically deleterious manner.

Even-aged silviculture can discriminate against shade-tolerant mast tree species such as American beech (Fagus grandifolia) and buckeye (Aesculus spp.; Nixon et al. 1968) that may be seasonally important to Allegheny woodrats. Timber harvesting may contribute to the temporary loss of important mid-tolerant and intolerant mast producers, such as oak and black cherry (Prunus serotina), further reducing the available food resources for this species. In Louisiana, Neal (1967) demonstrated a direct correlation between mast failures and a rapid decline in Eastern woodrat densities. Even though important shade intolerant mast producers in an industrial setting can only be sustained through even-aged management, the production of food resources is lost for 30-50 years. In an uneven-aged system there may be an inability to regenerate many of the shade intolerant mast producers and these important food resources may be lost permanently. Although the effects of timber harvesting may be detrimental to some important food resources, these effects may be partially negated by the rapid flush of understory growth that follows 1-5 years after canopy removal. This understory growth provides high quality, succulent forage, as well as soft mast such as greenbrier (Smilax spp.), blackberry (Rubus spp.), and grape (Vitis spp.; Ripley and Campbell 1960, Della-Bianca and Johnson 1965, Moore and Downing 1965, Harlow et al. 1966, Johnson and Landers 1978, Ford et al. 1993). 
In addition, food items in clearcuts can be nutritionally superior to forest forages (Thill et al. 1990, Hughes and Fahey 1991) although Ford et al. (1994) found few differences in the nutritional quality of forages in clearcuts when compared to the surrounding forests in the southern Appalachians.

Because current forest management practices may be affecting available food resources, forest managers in both the public and private sectors are increasingly in need of information regarding their effects. Research regarding changes in food resources as a result of timber harvesting have focused on game species such as deer (Odocoileus virginianus), squirrels (Sciurus carolinensis and S. niger), bobwhite quail (Colinus virginianus), and turkey (Meleagris gallopavo) (Moore and Downing 1965, Della-Bianca and Johnson 1965, Harlow et al. 1966, Harlow and Downing 1969, Reid and Goodrum 1957, Crawford et al. 1975, Nixon et al. 1980a,b; Exum et al. 1987, Nixon et al. 1987,Wentworth et al. 1990, Hughes and Fahey 1991, Ford et al. 1993, Ford et al. 1994, and others). Most research regarding the effects of timber harvest on small mammals has focused on changes in community assemblages and the abundance of individual species (Kirkland 1977, 1990; Swan et al. 1984, Monthey and Soutiere 1985, Von Trebra 1998), while almost no attention has been given to the availability of food resources after harvest.

Our objective was to determine the effects of common timber harvest methods used in the Central Appalachians on Allegheny woodrat food habits. We hypothesized that: 1) use of important hard mast and fungi would be highest at uncut sites and lowest at clearcut sites; 2) use of soft mast and green vegetation would be highest at clearcut sites and lowest at uncut sights; and 3) species richness and diversity values would be lowest at diameter-limit sites and highest at clearcut sites. 
STUDY AREA

Woodrat trapping to collect food-habits data was conducted on Westvaco Corporations' Wildlife and Ecosystem Research Forest (WWERF) and surrounding company tracts in Randolph county, West Virginia. The WWERF was established in 1994 to examine the effects of intensive industrial forest management on Appalachian systems. The site is a 3,630-ha, actively managed forest dominated by second- and third-growth forests. Elevations range from 740-1200 $\mathrm{m}$ and precipitation ranges from 170-190 cm per year (Barrett 1995). Woodrat colony sites are generally found along ridgetops in sandstone outcrops. Due to frequent freezing and thawing, fissures and crevices have developed that are used by woodrats as den sites. Northern hardwood forest communities of American beech (Fagus grandifolia)-yellow birch (Betula lutea)-maple (Acer spp.) predominate on the forest. Lower elevations have mixed mesophytic species such as yellow-poplar (Liriodendron tulipifera), northern red oak (Quercus rubrum), American basswood (Tilia americana), and black birch (B. lenta). At the highest elevations and along sheltered riparian areas, red spruce (Picea rubens)-eastern hemlock (Tsuga canadensis) forests are present. A dense growth of rosebay rhododendron (Rhododendron maximum), mountain laurel (Kalmia latifolia), and greenbrier (Smilax spp.) occurs throughout the WWERF.

Timber harvest methods commonly employed on regional industrial forests include two-aged regeneration cuts, clearcuts, and diameter-limit harvests. Harvest method is determined by management objectives, site quality, and stand age. Two-aged regeneration harvests remove all trees except 6-10 residual trees/ha which are retained until the next harvest. This method is commonly used when wildlife or aesthetics are important (Barrett 1995). Clearcutting removes all trees $>2.54 \mathrm{~cm}$ dbh 
and is used to promote the growth of fast growing, shade intolerant species. All trees of a prespecified dbh are removed in diameter-limit harvests. On the WWERF, tress $>40 \mathrm{~cm}$ dbh were extracted for sawlog production. This method is not considered a silviculturally accepted management technique (Smith 1986), but is commonly used throughout the Appalachian region.

Woodrat fecal samples were collected from 3 1-3-year-old clearcuts and a 3-year-old twoaged stand located adjacent to colony sites. The vegetative response of these 2 methods are similar, especially near colony sites on the WWERF where outcrops and steep terrain prevent harvest of all trees within clearcut sites. Colony sites at clearcuts and two-aged stands were located along ridgetops where the cut approached the rock outcrop on 1 side, leaving intact forest along the other side of the colony site. Because the resulting levels of disturbance and vegetative communities are similar, these 2 types were pooled and will be referred to herein as clearcuts. Three 2-5-year-old diameter-limit harvests were selected. At diameter-limit harvests, the cut completely surrounded the colony sites, leaving no intact forest. Four uncut sites were chosen to serve as controls. These harvest methods represent a progression in disturbance with uncut controls representing no recent disturbance (in the last 50-100 years), diameter-limit harvests representing a medium level of disturbance, and clearcut harvests as the greatest level of disturbance. Sites were selected to be as homogeneous as possible and to represent harvest practices on the WWERF (Table 1).

\section{METHODS AND MATERIALS}

Fecal samples were collected for 15 months from live-trapped Allegheny woodrats at the WWERF. Feces were collected from marked animals by placing a canvas catchsheet under 
Tomahawk® live traps. All trapped animals were ear tagged for future identification and age, sex, and reproductive status were recorded. Fecal samples were preserved in 5\% formalin or $95 \%$ Ethanol until analysis was conducted (Davitt and Nelson 1980).

Fecal material was analyzed at the Washington State University Wildlife Habitat and Nutrition Laboratory using techniques described by Baumgartner and Martin (1939) as modified by Davitt and Nelson (1980). One slide per sample was made and 20 fields of view per slide were examined (Baumgartner and Martin 1939, McIntire and Carey 1989). A field of view is defined as the area delimited by the microscope field at 100X (Wydeven and Dahlgren 1982). Each diet component was recorded and all food items were described to the most specific taxon possible. In some cases, plant genera were combined due to difficulty in distinguishing between similar cell structures.

Reference slides to aid in food item identification were prepared at the Washington State University Wildlife and Nutrition Lab using potential food items collected from areas surrounding each site or found cached in middens. Plant leaf, bud, stem and flower parts were dried for storage before preparation. Permanent slide mounts were prepared using techniques described by Davitt and Nelson (1980) for comparison to items found in feces. A complete list of all reference material is available in Appendix A.

Percent frequency of each plant item was determined using the frequency conversion technique (Sparks and Malechek 1968). This method determines the presence or absence of each species in each location using a frequency percent calculated as the number of fields in which the species occurs out of the total number of fields examined. This method is as accurate as particle density but does not require counting all recognizable fragments of each species (Sparks and Malechek 1968). 
Specific food items were described for each timber harvest type. For statistical analysis, food items were combined into the following categories: hard mast, soft mast, other seeds, fungi, lichens, green vegetation, and insects. Hard mast was defined as fruit with a dry or hard exterior that is not wind disseminated. Soft mast was defined as fruit with a soft or fleshy exterior (Huntley 1990). Other seeds were defined as all seeds that did not fit into either of the other seed/fruit categories. Shannon diversity index $(\mathrm{H})$ and species richness (total number of food items), were calculated for each treatment type (Shannon and Weaver 1963, Magurran 1988). Total food item richness and diversity were calculated as the total number of food items found in the diet regardless of species. For example, if woodrats ate acorns, leaves, and buds of an oak species, the richness value would be 3 . Species richness and diversity measured the total number of species present in the diet. Using the former example, the richness value in this case would be 1 . Comparisons were made among timber harvest types using 2-way analysis of variance (ANOVA). Because data did not meet the assumptions of normality and homogeneity of variance and transformations were unsuccessful, ANOVA was performed on ranked (PROC RANK; SAS Institute 1990) data using general linear models (PROC GLM; SAS Institute 1990) with timber harvest type as the fixed effect and site nested within harvest type as the random effect. This method is the equivalent of a Kruskall Wallis non-parametric test, but allows for complex models and different sample sizes among treatments (Sokal and Rohlf 1995). When differences $(\%=0.10)$ were detected Tukey's Studentized Range (HSD) test was used to separate ranked means (Steel and Torrie 1980). 


\section{RESULTS}

Eighty seven fecal pellet samples were collected from woodrats from clearcut sites $(n=17)$, diameter-limit sites $(n=15)$, and unharvested sites $(n=55)$. The most highly used foods over the entire sampling period (in order of importance) at clearcut sites were fungi, soft mast, green vegetation, lichen and fern (Table 2). At diameter-limit sites the most highly used foods were soft mast, green vegetation, lichen, and fungi. At uncut sites, woodrats chiefly consumed green vegetation, fungi, soft mast, fern, and hard mast.

There were no significant differences $(\mathrm{P}>0.12)$ in food habits of Allegheny woodrats among any of the treatment types (Table 2). Additionally, we saw no differences $(\mathrm{P}>0.23)$ in species or total food item richness or diversity values for any of our treatments (Table 2). Site nested within harvest type was significant $(\mathrm{P}<0.1$; Table 2$)$ for most of the comparisons examined. This suggests that we had high among-site variation that may have reduced our ability to detect differences among treatments.

\section{DISCUSSION}

The effects of clearcuts

Clearcutting represents the greatest amount of site disturbance of all 3 treatments (Smith 1986, Barrett 1995, Hicks 1998). Although the effects of clearcuts may reduce the availability of important food resources, we suspected these effects could be partially negated by the rapid flush of regenerating vegetation following canopy removal. This growth provides a large amount of succulent forage as well as soft mast such as greenbrier, blackberry (Rubus spp.), and grape (Vitis spp.; Ripley and Campbell 1960, Della-Bianca and Johnson 1965, Moore and Downing 1965, Harlow et al. 1966, Johnson and 
Landers 1978, Ford et al. 1993). In our study, soft mast use was highest at diameter-limit harvests, although woodrats used more soft mast at clearcut sites than at unharvested sites. Woodrats at clearcut sites had more soft mast available in the understory from grapes, blueberries, blackberries, and greenbrier, but overstory soft mast producers, such as black cherry, were nearly eliminated (Table 1). Woodrats consumed more green vegetation at uncut sites and diameter-limit harvest than clearcuts even though there was more vegetative ground cover available at clearcut and diameter-limit sites (Table 1). This could be due to the potentially higher nutritional value of foods produced in clearcuts (Thill et al. 1990, Hughes and Fahey 1991) from increased concentrations of mineral nutrients in the soil such as calcium, phosphorous, and potassium (Hooven 1973). These higher nutritional levels may lower the amount of food required by woodrats at clearcut sites to meet daily nutritional requirements.

Fungi use was almost twice as high at clearcuts as diameter-limit harvests or intact forest. The higher amounts of woody debris available at harvested sites (Table 1) would favor the growth of mushrooms. Additionally, fungi grows in greater abundance along forest edges than either open areas or intact forest (D. Mitchell, West Virginia Division of Natural Resources, pers. comm.) meaning woodrats at clearcut sites may have access to higher amounts of fungi than individuals at either diameter-limit sites or forested sites.

\section{The effects of diameter limit harvests}

Diameter limit harvests represent an intermediate level of disturbance where there has been removal of scattered individual trees. This method creates relatively small openings and does not drastically decrease crown cover (Table 1). Understory plant occurrence and production may actually 
increase in the openings created, but only a small part of the overall area is affected. Since not all trees are removed, limited amounts of quality woodrat foods such as fungi, hard mast, and soft mast may still be available (Table 1).

Use of soft mast was highest at diameter limit sites. A few, scattered soft mast producing trees, such as black cherry and fire cherry, were still available on the site as well as a flush of growth, primarily greenbrier, from the removal of canopy trees (Table 1). Greenbrier leaves and fruits are highly used foods of Allegheny woodrats documented in this study. Use of hard mast, a seasonally important food resource, was higher at diameter limit sites than uncut sites, but was lower than unharvested sites. Almost all of the larger, quality mast producers had been removed from the site (Table 1) which would result in a smaller mast crop from the remaining residual overstory trees.

\section{Other factors that may influence resource availability}

Orientation of the cut in relation to the colony site may influence resource availability. Colony sites at clearcuts were located along ridgetops where the cut approached the outcrop on one side, leaving intact forest on the opposite side. At diameter-limit harvests, the cut completely surrounded the colony site, leaving no intact forest. Thus, woodrats at clearcut sites had access to resources in the cut, as well as those of the intact forest. Woodrats from diameter limit sites were surrounded by disturbed forest.

Allegheny woodrats at disturbed sites have larger home ranges and move farther away from the colony site than individuals at undisturbed sites (Castleberry in prep.). This may be a response to the restricted availability of food resources following timber harvest. Woodrats must move farther away 
from the colony site to obtain the required food resources. This adaptive response to foraging movements could further explain why significant differences were not observed in food habits among treatment types.

Hard mast, especially acorns, is seasonally one of the most important foods to Allegheny woodrats. Acorns are high in fat and digestible energy (Reid and Goodrum 1957, Halls 1977), providing woodrats with a high quality, preservable food source during times of low food resource availability. Woodrats cache foods and rely on those foods during the winter and early spring. The low percentage of mast in the diet reflects the almost total mast failure in West Virginia during the fall of 1997 (Pack 1997). This resulted in a low percentage of hard mast in the diet for the rest of the year. The use of hard mast increased in late summer and fall 1998 (see Chapter 2), when the state had an excellent acorn crop (Pack 1998). Second, 2 of our 3 uncut sites were located in a northen hardwood stand and a spruce-hemlock stand, respectively, and all diameter-limit stands were located in northern hardwood communities. These communities naturally have a low abundance of oaks. Although, hard mast was not in the top 4 food items used in this study, other work has shown the importance of hard mast to woodrats and its importance should not be underestimated (Newcombe 1930, Poole 1936, 1940; Wagle and Feldhamer 1997, N.L. Castleberry, unpublished data).

Most woodrat species are generalist herbivores that are capable of adapting their feeding habits to local conditions and available food resources (Rainey 1956). Allegheny woodrats differ from other woodrat species because they are habitat specialists (Newcombe 1930, Poole, 1940). Because Allegheny woodrats rely on rocky habitats, they may be more severely affected by habitat change than other similar woodrat species. Allegheny woodrats cannot easily disperse and re-establish new home 
ranges without relocating to other rock outcrops. Because of this, habitat changes could cause localized extirpations if disturbances are severe, where similar disturbances in other woodrat species may cause little effect. When affected by changes in habitat, Allegheny woodrats have been shown to shift their diets and expand their home-ranges to compensate for losses of necessary resources (Castleberry in prep.). Research is needed to examine the effects of these changes on survivorship, overall condition, and reproductive success of this species.

\section{MANAGEMENT IMPLICATIONS}

Our data suggest timber management can occur within close proximity to woodrat colony sites without seriously impacting food utilization. Allegheny woodrats persisted by expanding their home ranges and by using intact forested habitat within harvested areas (Castleberry, in prep.). Diameter limit harvests appeared to have the largest impact on woodrat food habits because harvests totally surrounded colony sites and no intact forest remained. Woodrats had to utilize alternate foods and travel farther from the colony site to obtain required food resources (Castleberry in prep.). At clearcuts, woodrats had access to high quality food resources within the intact forest adjacent to colony sites as well as high quality forage and soft mast from the regenerating clearcut.

When planning timber harvests, managers should leave a forested buffer around woodrat colony sites. When clearcuts totally surrounded colony sites, we never captured woodrats, even when old woodrat sign such as middens or latrines were present. Canopy removal causes dramatic changes to the micro-climate of a site by increasing wind exposure and solar radiation (Ranney et al. 1981, Franklin and Forman 1987). Buffers would provide required food resources as well as protect the 
microclimate of the site. Buffers of mature trees, $50-100 \mathrm{~m}$ wide should be retained for approximately 30 years after cutting to allow trees within clearcuts to reach seed-producing age (Nixon et al. 1980b). Shaw (1971) suggests leaving buffers cut by single tree or small-group cuts, leaving a stand capable of producing at least $112 \mathrm{~kg} / \mathrm{ha}$ of winter-storable foods for squirrels. This would require approximately 7 $\mathrm{m}^{2} /$ ha of basal area of seed producing trees (Holbrook 1973). Buffers should contain mature hard and soft mast producing trees to provide a variety of high quality food items throughout the year (Reid and Goodrum 1957, Goodrum et al. 1971). Ideally, timber harvests should be planned so that they approach the colony on one side, but leave intact forest on the other, providing woodrats with a variety of seres for foraging and protecting the micro-climate of the site.

Within clearcut and diameter-limit harvested sites, logging crews often remove undesirable tree species $>5 \mathrm{~cm}$ dbh left after the harvest. This practice removes smaller mast producing species such as dogwoods (Cornus spp.), hornbeam (Carpinus caroliniana), and hophornbeam (Ostrya virginiana) that sometimes produce the only reliable mast crop during the first years of stand regrowth (Nixon et al. 1980b). Mast production is higher in the small understory trees for these species than for larger trees in the overstory (Lay 1961). Nixon et al. (1980b) recommended leaving a minimum of 0.4-0.7 $\mathrm{m}^{2} /$ ha of important understory mast producers for wildlife in new clearcuts.

The shift to less intensive harvesting methods such as deferment and single-tree selection harvests, in both private and public forests will require more frequent and more widespread disturbance to a site if current timber production is held constant (Taulman et al. 1998). To ensure the continuity of woodrats and other forest-dependent mammals such as northern and southern flying squirrels (Taulman et al. 1998), and gray squirrels (Nixon et al. 1980a,b; Brown and Batzli 1984) landscape management 
is important. By managing both on the stand and landscape levels managers can preserve areas of mature, undisturbed forests, and retain mature, mast producing hardwoods within and around harvested sites near rocky habitats (Pulliam 1988, Bright 1993, Noss 1993, Dunstan and Fox 1996, Taulman et al. 1998).

LITERATURE CITED

BARRETT, J. W. 1995. The Southern Appalachian Hardwood Region: in: Regional Silviculture of the United States. John Wiley and Sons, Inc. New York. 643 pp.

BAumgartner, L. L., AND A. C. MARTIN. 1939. Plant histology as an aid in squirrel food-habits studies. J. Wildl. Manage. 3:266-268.

BEANS, B. E. 1992. Without a trace: The puzzling demise of the Allegheny woodrat. Audubon. 92:32-34.

BRIGHT, P. W. 1993. Habitat fragmentation-problems and predictions for British mammals. Mammal Review 23:101-111.

BROWN, B. W., AND G. O. BATZLI. 1984. Habitat selection by fox and gray squirrels: a multivariate analysis. J. Wildl. Manage. 48:616-621.

Crawford, H.S., J. B. Whelan, R.F. Harlow, And J. E. SKeEN. 1975. Deer range potential in selective and clearcut oak-pine stands in Southwestern Virginia. Res. Pap. SE-134, USDA Forest Service, Asheville, NC, 12pp.

CASTLEBERry, S. B. In prep. Conservation of the Allegheny woodrat in the central Appalachians. Ph.D. Dissertation, West Virginia University, Morgantown. 
DAVITT, B. B., AND J. R. NELSON. 1980. A method of preparing plant epidermal tissue for use in fecal analysis. College of Agriculture Research Center, Washington State University Circular 0628.

DELlA-BIANCA, L., AND F. M. JOHNSON. 1965. Effect of an intensive cleaning on deer-browse production in the Southeastern Appalachians. J. Wildl. Manage. 29:729-733.

Dunstan, C. E., AND B. J. FoX. 1996. The effects of fragmentation and disturbance of rainforest on ground-dwelling small mammals on the Robertson Plateau, New South Wales, Austrailia. J. of Biogeog. 23:187-201.

EXuM, J. H., J. A. MCGLinCy, D. W. SPEAKE, J. L. BuCKNER, AND F. M. StANLEY. 1987. Ecology of the eastern wild turkey in an intensively managed pine forest in southern Alabama. Bull. No. 23 of Tall Timbers Res. Sta., Tallahassee, FL. 70pp.

FINLEY, R. B., JR. 1958. The wood rats of Colorado: distribution and ecology. Univ. Kans. Mus. Nat. His. Publ. 10:213-552.

FITCH, H. S. AND D. G. RAINEY. 1956. Ecological observations on the woodrat, Neotoma floridana. Univ. Kansas Publ., Mus. Nat. Hist. 8:499-533.

FORD, W. M., A. S. JOHNSON AND P. E. HALE. 1994. Nutritional quality of deer browse in Southern Appalachian clearcuts and mature forests. For. Ecol. Manage. 67:149-157. AND J. M. WENTWORTH. 1993. Availability and use of spring and summer woody browse by deer in clearcut and uncut forests of the Southern Appalachians. South. J. Appl. For. 17:116-119.

FRANKLIN, J. F., AND R. T. T. FORMAN. 1987. Creating landscape patterns by forest cutting; ecological consequences and principles. Landscape Ecology. 1:5-8. 
GOODRUM, P. D., V. H. REID, AND C. E. BOYD. 1971. Acorn yields, characteristics, and management criteria of oaks for wildlife. J. Wildl. Mange. 35:520-532.

HaLl, E. R. 1981. The mammals of North America. $2^{\text {nd }}$. Ed. John Wiley and Sons, New York.

HALL, J. S. 1988. Survey of the woodrat in Pennsylvania. Final Report. Pennsylvania Game Commission, Harrisburg, PA.

HALLS, L. K. (ED). 1977. Southern Fruit-producing Woody Plants Used by Wildlife. Southern For. Expt. Sta. U.S.D.A. For. Serv. Gen. Tech. Rept. SO-16.

HARLOW, R. F. AND R. L. DOWNING. 1969. The effects of size and intensity of cut on production and utilization of some deer foods in the Southern Appalachians. Trans. Northeast. Fish and Wildl. Conf. 26:45-55.

, D. D. StRode, AND L. M. OliPhANT. 1966. Timber and deer thrive under even-age management. South. Lumberman. 213 (2656):118-120.

HiCKS, A. 1989. What happened to the Allegheny woodrat? Pp. 34-38 in: The Conservationist (March-April), New York State Dept. of Environmental Conservation, Albany.

HICKS, R. R., JR. 1998. Ecology and Management of Central Hardwood Forests. John Wiley and Sons, Inc. New York, NY.

HolBROOK, H. L. 1973. Management of wild turkey habitat in southern forest types. Pp 245-252 in G. C. Sanderson and H. C. Schultz, eds. Wild turkey management: current problems and programs. Univ. Missouri Press, Columbia. 355pp.

HoOvEN, E. F. 1973. A wildlife brief for the clearcut logging of Douglas fir. J. For. 71:210-214. 
HoRnE, E. A. 1996. Construction, use, and defense of a central food cache by the eastern woodrat, Neotoma floridana, Ph.D. Dissertation, Kansas State University, Manhattan. 111p.

HUNTLEY, J. C. 1990. Importance and management of mast species other than oaks. pp. 74-82 in: McGee, C. E. ed. Proceedings of the workshop: Southern Appalachian mast management; 1989 August 14-16; Knoxville, TN. U. S. D. A. For. Serv., Southern Region, Cherokee Natl. For.

HuGES, J. W., AND T. J. FAHEY. 1991. Availability, quality, and selection of browse by white-tailed deer after clearcutting. For. Sci. 37:261-270.

JOHNSON, S. A., AND L. J. LANDERS. 1978. Fruit production in slash pine plantations in Georgia. J. Wildl. Manange. 42:606-613.

KIRKLAND, G. L., JR. 1977. Responses of small mammals to the clearcutting of Northern Appalachian Forests. J. Mammal. 58:600-609. 1990. Patterns of initial small mammal community change after clearcutting of temperate North American forests. Oikos. 59:313-320.

LAY, D. W. 1961. Fruit production of some understory hardwoods. Poc. Southeast. Assoc. Game and Fish Comm. 15:30-37.

LindSDALE, J. M., AND L. P. TEVIS, JR. 1951. The dusky-footed woodrat. Univ. of Calif. Press, Berkeley. 664 pp.

Magurran, A. E. 1988. Ecological diversity and its measurement. Princeton Univ. Press. Princeton, NJ. 179 pp. 
MCInTIRE, P. W., AND A. B. CAREY. 1989. A Microhistological Technique for Analysis of Food Habits of Mycophagous Rodents. U. S. D. A. For. Serv. Pacific Northwest Res. Stn. Res. Pap. 404.

MENGAK, M. T. 1996. Status and distribution of woodrat metapopulations in Virginia. pp 2-4 in: Abstracts of the 1996 Allegheny Woodrat Recovery Group Meeting., Ferrum College, Ferrum VA.

MONTHEY, R. W., AND E. C. SOUTIERE. 1985. Responses of small mammals to forest harvesting in northern Maine. The Canadian Field Nat. 99:13-18.

MOORE, W. H., AND R. L. DOWNING. 1965. Some multiple-use benefits of even-aged management in the Southern Appalachians. Proc. Soc. Am. For. Conf. 227-229.

MURPHY, M.. F. 1952. Ecology and helminths of the osage wood rat, Neotoma floridana osagensis, including the description of the Longistriata neotoma n. sp. (Trichostoronblidae). Amer. Midl. Nat. 48:204-218.

NEAL, W. A. 1967. A study of the ecology of the woodrat in the hardwood forests of the lower Mississippi river basin. M. S. Thesis. Louisiana State University.

NewCOMBE, C. L. 1930. An ecological study of the Allegheny wood rat. J. Mammal. 11:204-211.

NiXON, C. M., AND L. P. HANSEN. 1987. Managing forests to maintain populations of gray and fox squirrels. Ill. Dept. Conserv. Tech. Bull. 5., Springfield. 35 pp. S. P. HAVERA, AND L. P. HANSEN. 1980a. Initial response of squirrels to forest changes associated with selection cutting. Wildl. Soc. Bull. 8:298-306. 
M.. W. MCClain, AND R. W. DONPOHOE. 1980b. Effects of clear-cutting on gray squirrels. J. Wildl. Mange. 44:534-539.

, D. M. Worley, AND M. W. MCCLAin. 1968. Food habits of squirrels in southeast Ohio. J. Wildl. Mange. 32:294-305.

Noss, R. F. 1993. Wildlife corridors. Pp. 43-68 in D. S. Smith and P. C. Hellmund, eds. Ecology of greenways: design and function of linear conservation areas. Univ. Minnesota Press, Minneapolis.

PACK, J. C. 1997. 1997 Mast survey and West Virginia Hunting Outlook. West Virginia Department of Natural Resources, Unpub. Rept. . 1998. 1998 Mast survey and West Virginia Hunting Outlook. West Virginia Depatment of Natural Resources, Unpub. Rept.

PARKS, H. E. 1922. The genus Neotoma in the Santa Cruz Mountains. J. Mammal. 3:241-253.

PoOLE, E. L. 1936. Notes on the young of the Allegheny wood rat. J. Mammal. 17:22-26. 1940. A Life history sketch of the Allegheny woodrat. J. Mammal. 21:249-270.

Post, D. M. 1993. Detection of differences in nutrient concentrations by eastern woodrats (Neotoma floridana). J. Mammal. 74:493-497.

Pulliam, H. R. 1988. Sources, sinks, and population regulation. Am. Nat. 132:652-661.

RANNEY, J. W., M. C. BRUNER, AND J. B. LEVENSON. 1981. The importance of edge in the structure and dynamics of forest islands, p. 67-95. in: R.L. Burgess and D.M. Sharpe (eds.). Forest island dynamics in man-dominated landscapes. Springer-Verlag, New York. 
RAINEY, D. G. 1956. Eastern woodrat: Neotoma floridana: life history and ecology. Univ. Kansas Publ., Mus. Nat. Hist. 8:369-375.

REID, V. H., AND P. D. GoOdRUM. 1957. The effect of hardwood removal on wildlife. Proc. Soc. Amer. For. (1957):141-147.

RIPLEY, T. H., AND R. A. CAMPBELL. 1960. Browsing and stand regeneration in clear and selectivelycut hardwoods. Trans. Northeast. Wildl. Conf. 25:407-415.

SAS InSTITUTE 1990. SAS User's guide. Version 6. SAS Institute, Cary, North Carolina, USA.

SHANNON, C. E., AND W. WEAVER. 1963. The mathematical theory of communication. Univ. Illinois Press, Urbabana, 117 pp.

SHAW, S. P. 1971. Wildlife and oak management. Pp. 84-89 in Proc. Oak Symp. U. S. D. A. For. Serv., Northeast. For. Exp. Stn.

SMITH, D. M. 1986. The practice of silviculture. Eighth edition. Wiley and Sons, New York, New York, USA. 257 pp.

SOKAL, R. R., AND F. J. RoHLF. 1995. Biometry. Third edition. W. H. Freeman and Co., New York, New York, USA. 887 pp.

SPARKS, D. R., AND J. C. MALECHEK. 1968. Estimating percentage dry weights in diets using a microscopic technique. J. Range Mange. 21:264-265.

STEEL, G. W., AND J. H. TORRIE. 1980. Principles and procedures of statistics. Second ed. McGraw Hill, New York. USA.

StiHLER, C. AND J. WAllace. 1996. Woodrat studies in West Virginia. p. 2., in: Abstracts of the 1996 Allegheny Woodrat Recovery Group Meeting., Ferrum College, Ferrum, Virginia. 
SWAN, D., B. FREEDMAN, AND T. DiLWORTH. 1984. Effects of various hardwood forest management practices on small mammals in Central Nova Scotia. Canadian Field-Nat. 98:362-364.

TAulman, J. F., K.G. SMith, AND R. E. THILl. 1998. Demographic and behavioral responses of southern flying squirrels to experimental logging in Arkansas. Ecol. App. 8:1144-1155.

THILL, R. E., H. F. MORRINS, AND A. T. HAVEL. 1990. Nutritional quality of deer diets from southern pine-hardwood forests. Am. Midl. Nat. 124:413-417.

Von TreBra, C., D. P. LAVENDER, AND T. P. Sullivan. 1998. Relations of small mammal populations to even-aged shelterwood systems in sub-boreal spruce forest. J. Wildl. Manage. 62:630-642.

VORHIES, C. T., AND W. P. TAYLOR. 1940. Life history and ecology of the white-throated wood rat, Neotoma albigula albigula Hartley, in relation to grazing in Arizona. Univ. Arizona, Coll. Agric., Tech. Bull. 86:455-529.

WAGLE, E. R., AND G. A. FeldHAMER. 1997. Feeding habits of the Eastern Woodrat (Neotoma floridana) in Southern Illinois. Transactions of the Illinois State Academy of Science. 90:171177.

Wentworth, J. M., A. S. Johnson, P. E. HALE, And K. E. KAMMERMEYer. 1990. Seasonal use of clearcuts and food plots by white-tailed deer in the Southern Appalachians. Proc. Annu. Conf. Southeast Assoc. Fish Wildl. Agencies. 44:215-223.

WILEY, R. W. 1980. Neotoma floridana. Mammalian Species, No. 139.

WYDEVEN, P. R., AND R. B. DAHLGREN. 1982. A comparison of prairie dog stomach contents and feces using a microhistological technique. J. Wildl. Mange. 46:1104-1108. 
Table 1. Means per 0.04 ha plot of 42 microhabitat habitat variables collected around Allegheny woodrat foraging locations by harvesting method at the Westvaco Wildlife and Ecosystem Research Forest, Randolph County, WV, 1998-99.

\begin{tabular}{|c|c|c|c|c|c|c|c|c|}
\hline \multirow[b]{3}{*}{ Variable } & \multicolumn{4}{|c|}{ Clearcut } & \multicolumn{2}{|c|}{ Diameter-limit } & \multicolumn{2}{|c|}{ Intact Forest } \\
\hline & \multicolumn{2}{|c|}{ Plots within clearcut } & \multicolumn{2}{|c|}{ Plots within forest } & \multirow[b]{2}{*}{0} & \multirow[b]{2}{*}{ SE } & \multirow[b]{2}{*}{0} & \multirow[b]{2}{*}{ SE } \\
\hline & 0 & SE & 0 & SE & & & & \\
\hline \multicolumn{9}{|l|}{ Overstory trees } \\
\hline Total trees & 6.93 & 1.24 & 21.28 & 1.30 & 19.96 & 0.70 & 19.85 & 0.97 \\
\hline Total trees $8.0-15.0 \mathrm{~cm}$ & 3.74 & 0.86 & 7.56 & 0.54 & 6.87 & 0.47 & 8.23 & 0.50 \\
\hline Total trees $15.1-30.0 \mathrm{~cm}$ & 1.52 & 0.36 & 7.06 & 0.55 & 6.74 & 0.34 & 7.30 & 0.45 \\
\hline Total trees $30.1-45.0 \mathrm{~cm}$ & 1.39 & 0.27 & 4.37 & 0.34 & 4.49 & 0.24 & 3.08 & 0.24 \\
\hline Total trees $>45.1 \mathrm{~cm}$ & 0.28 & 0.10 & 2.28 & 0.27 & 1.86 & 0.13 & 1.23 & 0.12 \\
\hline Hard mast & 2.37 & 0.55 & 3.51 & 0.45 & 1.98 & 0.29 & 2.19 & 0.32 \\
\hline Hard mast $8.0-15.0 \mathrm{~cm}$ & 1.13 & 0.37 & 0.61 & 0.15 & 0.55 & 0.12 & 0.40 & 0.10 \\
\hline Hard mast $15.1-30.0 \mathrm{~cm}$ & 0.52 & 0.13 & 1.42 & 0.22 & 0.69 & 0.11 & 0.88 & 0.15 \\
\hline Hard mast $30.1-45.0 \mathrm{~cm}$ & 0.59 & 0.15 & 1.00 & 0.17 & 0.55 & 0.12 & 0.56 & 0.11 \\
\hline Hard mast $>45.1 \mathrm{~cm}$ & 0.13 & 0.06 & 0.48 & 0.11 & 0.18 & 0.04 & 0.35 & 0.06 \\
\hline Soft mast & 0.54 & 0.18 & 1.47 & 0.43 & 2.74 & 0.27 & 7.04 & 0.72 \\
\hline Soft mast $8.0-15.0 \mathrm{~cm}$ & 0.39 & 0.14 & 0.86 & 0.29 & 1.11 & 0.14 & 3.93 & 0.40 \\
\hline Soft mast $15.1-30.0 \mathrm{~cm}$ & 0.02 & 0.02 & 0.36 & 0.11 & 1.08 & 0.15 & 2.55 & 0.33 \\
\hline Soft mast $30.1-45.0 \mathrm{~cm}$ & 0.13 & 0.07 & 0.20 & 0.11 & 0.43 & 0.07 & 0.48 & 0.09 \\
\hline
\end{tabular}




\begin{tabular}{|c|c|c|c|c|c|c|c|c|}
\hline \multirow[b]{3}{*}{ Variable } & \multicolumn{4}{|c|}{ Clearcut } & \multicolumn{2}{|c|}{ Diameter-limit } & \multicolumn{2}{|c|}{ Intact Forest } \\
\hline & \multicolumn{2}{|c|}{ Plots within clearcut } & \multicolumn{2}{|c|}{ Plots within forest } & \multirow[b]{2}{*}{0} & \multirow[b]{2}{*}{ SE } & \multirow[b]{2}{*}{0} & \multirow[b]{2}{*}{ SE } \\
\hline & 0 & SE & 0 & SE & & & & \\
\hline Soft mast $>45.1 \mathrm{~cm}$ & 0.00 & 0.00 & 0.05 & 0.02 & 0.12 & 0.03 & 0.08 & 0.03 \\
\hline Other seed & 4.02 & 0.81 & 16.30 & 1.13 & 15.25 & 0.72 & 10.62 & 0.80 \\
\hline Other seed $8.0-15.0 \mathrm{~cm}$ & 2.21 & 0.60 & 6.09 & 0.52 & 5.21 & 0.40 & 3.90 & 0.40 \\
\hline Other seed $15.1-30.0 \mathrm{~cm}$ & 0.98 & 0.26 & 5.28 & 0.48 & 4.97 & 0.32 & 3.87 & 0.35 \\
\hline Other seed $30.1-45.0 \mathrm{~cm}$ & 0.67 & 0.16 & 3.17 & 0.29 & 3.51 & 0.24 & 2.05 & 0.21 \\
\hline Other seed $>45.1 \mathrm{~cm}$ & 0.15 & 0.05 & 1.75 & 0.22 & 1.56 & 0.12 & 0.80 & 0.11 \\
\hline \multicolumn{9}{|l|}{ Understory Stems } \\
\hline Shrub & 57.67 & 8.79 & 23.53 & 4.70 & 50.56 & 5.87 & 65.91 & 7.18 \\
\hline Sapling & 18.30 & 2.45 & 10.95 & 2.21 & 4.65 & 0.57 & 10.50 & 1.56 \\
\hline Pole & 4.35 & 0.91 & 4.0 & 0.54 & 2.48 & 0.31 & 4.32 & 0.33 \\
\hline Rhododendron & 0.15 & 0.11 & 1.58 & 0.57 & 1.38 & 0.37 & 20.65 & 2.65 \\
\hline Greenbrier & 26.50 & 8.24 & 12.47 & 4.58 & 40.96 & 5.43 & 37.06 & 5.47 \\
\hline \multicolumn{9}{|l|}{ Percent Ground Cover } \\
\hline Forb & 6.20 & 0.93 & 4.06 & 1.03 & 2.35 & 0.53 & 3.35 & 0.56 \\
\hline Grass & 6.85 & 1.46 & 0.78 & 0.30 & 2.35 & 0.54 & 0.77 & 0.21 \\
\hline Fern & 5.43 & 1.39 & 5.78 & 1.26 & 6.23 & 0.99 & 6.12 & 1.06 \\
\hline
\end{tabular}




\begin{tabular}{|c|c|c|c|c|c|c|c|c|}
\hline \multirow[b]{3}{*}{ Variable } & \multicolumn{4}{|c|}{ Clearcut } & \multicolumn{2}{|c|}{ Diameter-limit } & \multicolumn{2}{|c|}{ Intact Forest } \\
\hline & \multicolumn{2}{|c|}{ Plots within clearcut } & \multicolumn{2}{|c|}{ Plots within forest } & \multirow[b]{2}{*}{0} & \multirow[b]{2}{*}{ SE } & \multirow[b]{2}{*}{0} & \multirow[b]{2}{*}{ SE } \\
\hline & 0 & SE & 0 & SE & & & & \\
\hline Greenbrier & 8.48 & 1.61 & 2.73 & 0.73 & 16.85 & 1.66 & 5.62 & 0.92 \\
\hline Moss & 1.52 & 1.47 & 4.06 & 0.11 & 1.42 & 0.27 & 2.42 & 0.35 \\
\hline Blackberry & 5.76 & 1.47 & 0.16 & 0.11 & 1.46 & 0.33 & 0.27 & 0.13 \\
\hline Woody shrub & 13.37 & 1.99 & 4.30 & 1.03 & 8.54 & 0.94 & 8.54 & 1.06 \\
\hline Woody debris & 11.52 & 1.80 & 9.38 & 0.99 & 11.69 & 0.94 & 8.08 & 0.77 \\
\hline Leaf litter & 21.96 & 2.67 & 49.22 & 2.17 & 40.61 & 1.79 & 50.96 & 0.77 \\
\hline Canopy & 15.54 & 2.42 & 78.20 & 2.07 & 71.38 & 1.65 & 78.88 & 1.91 \\
\hline \multicolumn{9}{|l|}{ Richness and Diversity } \\
\hline Understory richness & 6.89 & 0.55 & 4.97 & 0.30 & 4.99 & 0.22 & 5.28 & 0.24 \\
\hline Understory diversity & 1.26 & 0.09 & 1.04 & 0.05 & 0.90 & 0.05 & 1.10 & 0.04 \\
\hline Overstory richness & 2.74 & 0.41 & 5.83 & 0.25 & 5.57 & 0.15 & 5.19 & 0.21 \\
\hline Overstory diversity & 0.67 & 0.11 & 1.40 & 0.05 & 1.37 & 0.03 & 1.26 & 0.05 \\
\hline Total richness & 8.26 & 0.60 & 8.86 & 0.28 & 8.81 & 0.22 & 8.76 & 0.25 \\
\hline Total diversity & 1.41 & 0.9 & 1.64 & 0.04 & 1.48 & 0.04 & 1.57 & 0.04 \\
\hline Aspect & 157.87 & 15.91 & 257.73 & 14.55 & 227.26 & 7.03 & 213.76 & 6.54 \\
\hline
\end{tabular}


Table 2. Foods found in the diets of Allegheny woodrats from November 1997- December 1998 in uncut forests, diameter-limit harvests, and clearcuts in the Allegheny Plateau of West Virginia. Data are expressed as a percent of the total diet \pm SE.

\begin{tabular}{|c|c|c|c|c|c|c|}
\hline Variable & $\begin{array}{l}\text { Uncut } \\
(n=55)\end{array}$ & $\begin{array}{c}\text { Diameter- } \\
\text { limit } \\
(n=15) \\
\end{array}$ & $\begin{array}{c}\text { Clearcut } \\
(n=17)\end{array}$ & $F$ & $P$ & $d f$ \\
\hline \multicolumn{7}{|l|}{ Food group } \\
\hline Fungi & $15.5 \pm 2.7$ & $15.6 \pm 4.1$ & $27.7 \pm 6.6$ & 0.15 & 0.87 & 2,8 \\
\hline Hard mast & $10.5 \pm 2.3$ & $8.7 \pm 5.9$ & $2.9 \pm 1.9$ & 0.85 & 0.46 & 2,8 \\
\hline Soft mast & $15.4 \pm 2.5$ & $27.5 \pm 8.0$ & $18.3 \pm 8.8$ & 0.97 & 0.45 & 2,8 \\
\hline Fern & $10.7 \pm 2.6$ & $1.6 \pm 1.2$ & $8.3 \pm 5.3$ & 0.71 & 0.52 & 2,8 \\
\hline Other seeds & $1.5 \pm 0.5$ & $0.7 \pm 0.5$ & $0.4 \pm 0.4$ & 0.63 & 0.56 & 2,8 \\
\hline Lichen & $4.4 \pm 1.0$ & $19.4 \pm 6.8$ & $8.8 \pm 2.4$ & 0.08 & 0.92 & 2,8 \\
\hline Animal & $1.0 \pm 0.3$ & $0.7 \pm 0.5$ & $1.3 \pm 0.5$ & 0.06 & 0.94 & 2,8 \\
\hline Green vegetation & $37.5 \pm 3.9$ & $23.3 \pm 5.2$ & $17.9 \pm 8.0$ & 3.66 & 0.12 & 2,8 \\
\hline Species Richness $^{\mathrm{a}}$ & $10.1 \pm 0.4$ & $8.7 \pm 0.9$ & $8.1 \pm 0.7$ & 1.80 & 0.23 & 2,8 \\
\hline Species diversity ${ }^{a}$ & $1.8 \pm 0.1$ & $1.5 \pm 0.1$ & $1.6 \pm 0.1$ & 0.78 & 0.49 & 2,8 \\
\hline Total richness ${ }^{\mathrm{b}}$ & $10.7 \pm 0.4$ & $9.2 \pm 0.9$ & $9.1 \pm 0.7$ & 1.10 & 0.38 & 2,8 \\
\hline Total diversity $^{\mathrm{b}}$ & $1.9 \pm 0.1$ & $1.6 \pm 0.1$ & $1.7 \pm 0.1$ & 0.49 & 0.63 & 2,8 \\
\hline
\end{tabular}

${ }^{a}$ Species richness and diversity were calculated with all species that occurred in the diet.

${ }^{\mathrm{b}}$ Total richness and diversity were calculated with all possible food items found in the diet. 


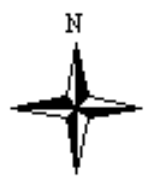

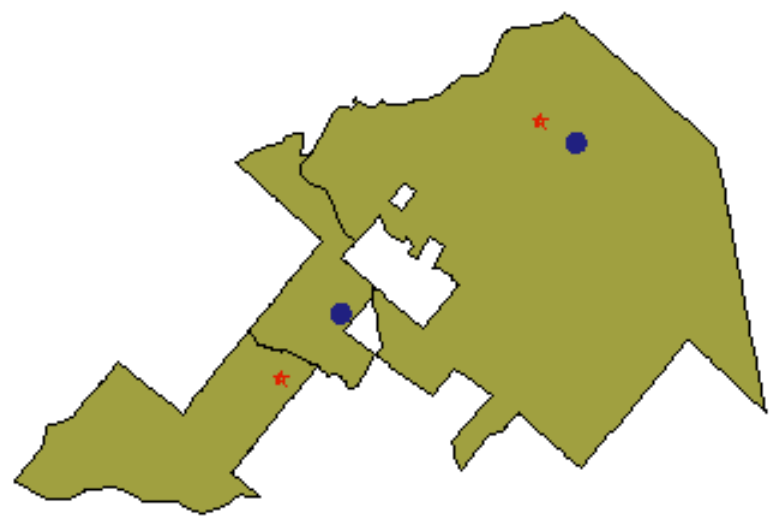

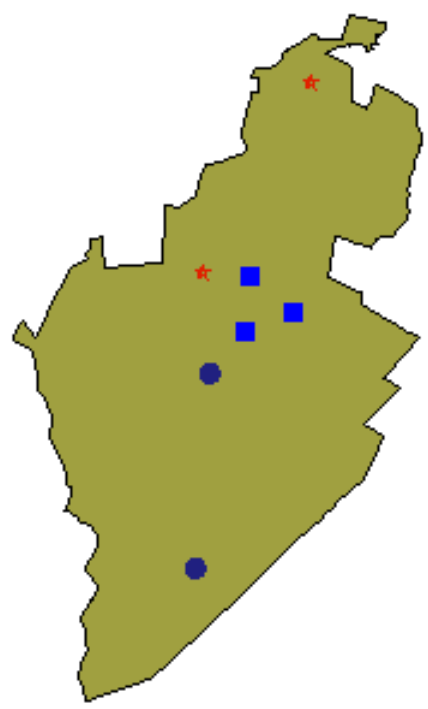

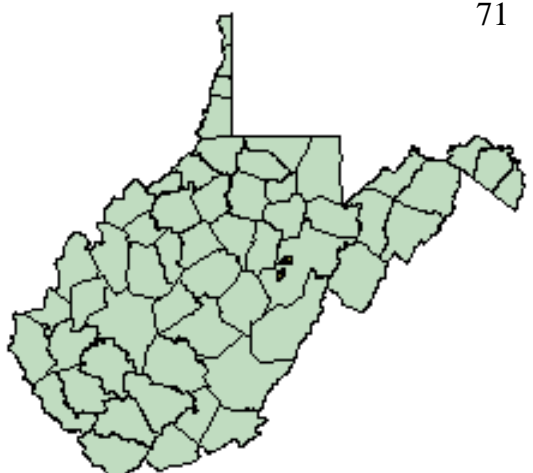

Timber harvest types on the Westvaco Wildife and Ecosystem Research Forest and surrounding Westvaco Properties

* Clearcut

- Intact forest

- Diameter-limit

Figure 1. Locations of clearcut, intact forest, and diameter-limit stands on the Westvaco Wildlife and Ecosystem Research Forest and surrounding Westvaco Properties in Randolph Co., WV, 1997-1998. 
APPENDIX A

PLANT SPECIES COLLECTED AS REFERENCE MATERIAL TO AID IN THE IDENTIFICATION OF FOOD ITEMS OF ALLEGHENY WOODRAT FROM THE ALLEGHENY PLATEAU AND RIDGE AND VALLEY PHYSIOGRAPHIC PROVINCES OF VIRGINIA AND WEST VIRGINIA, 1997-1998. 
Appendix A. Plant, fungal, and lichen species used to aid in the identification of food items of Allegheny woodrats from the Ridge and Valley and Allegheny Plateau physiographic provinces of West Virginia and Virginia, 1997-1998. Species are arranged alphabetically by genus. Taxonomy of the vascular plants follows Strausbaugh and Core (1977) and fungi follows Lincoff and Knopf (1988)

\section{SCIENTIFIC NAME}

\section{PLANTS}

Acer pennsylvanicum

Acer rubrum

Acer saccharum

Acer spicatum

Albizia julibrissin

Alnus serrulata

Amelanchier arborea

Amelanchier laevis

Aralia spinosa

Arisaema triphyllum

Aristolochia macrophylla

Aster divaricatus

Betula alleghaniensis / lutea

Betula lenta

Bidens tripartita

Carpinus caroliniana

Carya cordiformis

Carya glabra

Carya ovata

Carya tomentosa

Castanea dentata
COMMON NAME

Striped maple

Red maple

Sugar maple

Mountain maple

Mimosa

Brookside alder

Common serviceberry

Smooth serviceberry / Juneberry

Devil's walking stick

Jack in the pulpit

Dutchman's pipe

White wood aster

Yellow birch

Black birch

Beggartick

Ironwood

Bitternut hickory

Pignut hickory

Shagbark hickory

Mockernut hickory

American chestnut 


\begin{tabular}{|c|c|}
\hline SCIENTIFIC NAME & COMMON NAME \\
\hline Celtis occidentalis & American hackberry \\
\hline Cercis canadensis & Eastern redbud \\
\hline Clematis virginiana & Virgins bower \\
\hline Clintonia umbellulata & Speckled wood-lily \\
\hline Cornus spp. & Dogwood \\
\hline Crataegus spp. & Hawthorn \\
\hline Dennstaedtia punctilobula & Hay-scented fern \\
\hline Diospyros virginiana & Persimmon \\
\hline Dryopteris intermedia & Intermediate woodfern \\
\hline Dryopteris marginalis & Marginal shield fern \\
\hline Echinochloa crusgalli & Barnyard grass \\
\hline Elaeagnus spp. & Autumn olive \\
\hline Euonymus americanus & Strawberry bush \\
\hline Fagus grandifolia & American beech \\
\hline Gaultheria procumbens & Teaberry \\
\hline Hamamelis virginiana & Witch hazel \\
\hline Ilex montana & Mountain holly \\
\hline Impatiens spp. & Jewelweed \\
\hline Juglans nigra & Black walnut \\
\hline Ligustrum vulgare & Privet \\
\hline Lindera benzoin & Spicebush \\
\hline Liriodendron tulipifera & Yellow poplar \\
\hline Lobelia cardinalis & Cardinal flower \\
\hline Lonicera japonica & Japanese honeysuckle \\
\hline Magnolia acuminata & Cucumber magnolia \\
\hline
\end{tabular}




\begin{tabular}{|c|c|}
\hline SCIENTIFIC NAME & COMMON NAME \\
\hline Magnolia fraseri & Frasier magnolia \\
\hline Maianthemum canadense & Canada mayflower \\
\hline Monotropa uniflora & Indian pipe \\
\hline Morus rubra & Red mulberry \\
\hline Nyssa sylvatica & Blackgum \\
\hline Ostrya virginiana & Hophornbeam \\
\hline Oxalis spp. & Woodsorel \\
\hline Parthenocissus quinquefolia & Virginia creeper \\
\hline Phytolacca americana & Pokeberry \\
\hline Picea rubens & Red spruce \\
\hline Platanus occidentalis & American sycamore \\
\hline Poa spp. & Bluegrass \\
\hline Polygonum spp. & Smartweed \\
\hline Polystichum acrostichoides & Christmas fern \\
\hline Prenanthes spp. & Fall latice \\
\hline Prunus pennsylvanica & Fire cherry \\
\hline Prunus serotina & Black cherry \\
\hline Pteridium aquilinum & Bracken fern \\
\hline Quercus alba & White oak \\
\hline Quercus coccinea & Scarlet oak \\
\hline Quercus prinus & Chestnut oak \\
\hline Quercus rubrum & Northern red oak \\
\hline Quercus velutina & Black oak \\
\hline Rhododendron maximum & Great laurel \\
\hline Rhododendron nudiflorum & Pink honeysuckle \\
\hline
\end{tabular}




\begin{tabular}{|c|c|}
\hline SCIENTIFIC NAME & COMMON NAME \\
\hline Rhus copallina & Winged sumac \\
\hline Rhus glabra & Smooth sumac \\
\hline Rhus radicans & Poison ivy \\
\hline Robinia pseudoacacia & Black locust \\
\hline Rosa spp. & Rose \\
\hline Rubus hispidus & Hispadewberry \\
\hline Rubus spp. & Blackberry / Raspberry \\
\hline Sambucus canadensis & American elder \\
\hline Sassafras albidum & Sassafras \\
\hline Smilacina racemosa & False salomon's seal \\
\hline Smilax spp. & Greenbrier \\
\hline Solidago canadensis & Canada goldenrod \\
\hline Solidago graminifolia & Grass-leaved goldenrod \\
\hline Tilia americana & American basswood \\
\hline Tsuga canadensis & Eastern hemlock \\
\hline Tussilago farfara & Coalts foot \\
\hline Vaccinium spp. & Blueberry \\
\hline Viburnum spp. & Viburnum \\
\hline Viola blanda & Sweet white violet \\
\hline Vitis spp. & Grape \\
\hline \multicolumn{2}{|l|}{ FUNGI } \\
\hline Alpova diplophloeus & $\mathrm{N} / \mathrm{A}$ \\
\hline Elaphomyces granalatus & $\mathrm{N} / \mathrm{A}$ \\
\hline Elaphomyces spp. & N/A \\
\hline
\end{tabular}


Appendix A. Continued.

\begin{tabular}{ll}
\hline SCIENTIFIC NAME & COMMON NAME \\
\hline Endogone flammincorona & N/A \\
Gautieria graveolens & N/A \\
Geopora cooperi & N/A \\
Hystorangium coriaceum & N/A \\
UNKNOWN LICHEN & \\
\hline
\end{tabular}




\section{APPENDIX B.}

FOOD ITEMS THAT COMPOSED > 2\% OF THE TOTAL DIET OF ALLEGHENY

WOODRATS IN ANY SEASON FROM NOVEMBER 1997 THROUGH DECEMBER 1998 IN THE RIDGE AND VALLEY AND ALLEGHENY PLATEAU PHYSIOGRAPHIC PROVINCES OF WEST VIRGINIA AND VIRGINIA 
Appendix B. Food items that composed $>2 \%$ of the total diet in any season from Allegheny woodrats captured November 1997 through December 1998 in the Ridge and Valley (RV) and Allegheny Plateau (AP) Physiographic Provinces of West Virginia and Virginia. Expressed as percent of the total diet \pm (SE). Taxonomy of the vascular plants follows Strausbaugh and Core (1977) and fungi follows Lincoff and Knopf (1988).

\begin{tabular}{|c|c|c|c|c|c|c|c|c|c|c|}
\hline \multirow[t]{2}{*}{ Species } & \multicolumn{2}{|c|}{$\underline{\text { Fall } 1997}$} & \multicolumn{2}{|c|}{$\underline{\text { Winter } 1998}$} & \multicolumn{2}{|c|}{$\underline{\text { Spring } 1998}$} & \multicolumn{2}{|c|}{$\underline{\text { Summer } 1998}$} & \multicolumn{2}{|c|}{$\underline{\text { Fall } 1998}$} \\
\hline & $\begin{array}{c}\mathrm{AP} \\
(n=15)\end{array}$ & $\begin{array}{c}\mathrm{RV} \\
(n=11)\end{array}$ & $\begin{array}{c}\mathrm{AP} \\
(n=12)\end{array}$ & $\begin{array}{c}\mathrm{RV} \\
(n=13)\end{array}$ & $\begin{array}{c}\mathrm{AP} \\
(n=13)\end{array}$ & $\begin{array}{c}\mathrm{RV} \\
(n=14)\end{array}$ & $\begin{array}{c}\mathrm{AP} \\
(n=13)\end{array}$ & $\begin{array}{c}\mathrm{RV} \\
(n=8)\end{array}$ & $\begin{array}{c}\text { AP } \\
(n=15)\end{array}$ & $\begin{array}{c}\mathrm{RV} \\
(n=9)\end{array}$ \\
\hline \multicolumn{11}{|l|}{ FUNGI } \\
\hline Unknown fungi & $18.1 \pm 3.4$ & $0.4 \pm 0.4$ & $1.8 \pm 0.8$ & $0.4 \pm 0.4$ & $7.7 \pm 2.5$ & $11.3 \pm 4.0$ & $17.1 \pm 5.0$ & $1.3 \pm 0.9$ & $8.5 \pm 3.6$ & $2.2 \pm 2.2$ \\
\hline \multicolumn{11}{|l|}{ Gautieriales } \\
\hline \multicolumn{11}{|l|}{ Gautieriaceae } \\
\hline $\begin{array}{l}\text { Gautieria } \\
\text { morchelliformis }\end{array}$ & $4.8 \pm 4.0$ & $0.0 \pm 0.0$ & $0.0 \pm 0.0$ & $0.0 \pm 0.0$ & $0.0 \pm 0.0$ & $0.0 \pm 0.0$ & $1.7 \pm 1.5$ & $0.0 \pm 0.0$ & $0.0 \pm 0.0$ & $0.0 \pm 0.0$ \\
\hline \multicolumn{11}{|l|}{ Lycoperdales } \\
\hline $\begin{array}{l}\text { Unknown Puffball } \\
\text { fungi }\end{array}$ & $4.2+4.2$ & $0.0 \pm 0.0$ & $8.5 \pm 4.3$ & $0.0+0.0$ & $1.2 \pm 1.0$ & $0.0 \pm 0.0$ & $0.0 \pm 0.0$ & $1.1 \pm 1.1$ & $7.5 \pm 4.8$ & $4.2 \pm 3.4$ \\
\hline \multicolumn{11}{|l|}{ Aphyllophorales } \\
\hline Polyporaceae & $0.3 \pm 0.3$ & $0.0 \pm 0.0$ & $0.4 \pm 0.4$ & $0.8 \pm 0.8$ & $0.8 \pm 0.5$ & $2.1 \pm 0.6$ & $1.3 \pm 0.9$ & $0.9 \pm 0.9$ & $0.6 \pm 0.4$ & $2.0 \pm 1.8$ \\
\hline \multicolumn{11}{|l|}{ FERNS } \\
\hline \multicolumn{11}{|l|}{ Pteridophyta } \\
\hline \multicolumn{11}{|l|}{ Polypodiaceae } \\
\hline $\begin{array}{l}\text { Dryopteris } \\
\text { marginalis }\end{array}$ & $8.9 \pm 4.4$ & $2.5 \pm 1.7$ & $9.7 \pm 4.6$ & $11.7 \pm 5.7$ & $1.2 \pm 0.6$ & $2.2 \pm 1.9$ & $0.2 \pm 0.2$ & $0.0 \pm 0.0$ & $14.0 \pm 6.0$ & $1.5 \pm 1.5$ \\
\hline
\end{tabular}




\begin{tabular}{|c|c|c|c|c|c|c|c|c|c|c|}
\hline \multirow[t]{2}{*}{ Species } & \multicolumn{2}{|c|}{$\underline{\text { Fall } 1997}$} & \multicolumn{2}{|c|}{ Winter 1998} & \multicolumn{2}{|c|}{ Spring 1998} & \multicolumn{2}{|c|}{$\underline{\text { Summer } 1998}$} & \multicolumn{2}{|c|}{$\underline{\text { Fall } 1998}$} \\
\hline & $\begin{array}{c}\mathrm{AP} \\
(n=15)\end{array}$ & $\begin{array}{c}\mathrm{RV} \\
(n=11)\end{array}$ & $\begin{array}{c}\text { AP } \\
(n=12)\end{array}$ & $\begin{array}{c}\mathrm{RV} \\
(n=13)\end{array}$ & $\begin{array}{c}\text { AP } \\
(n=13)\end{array}$ & $\begin{array}{c}\mathrm{RV} \\
(n=14)\end{array}$ & $\underset{(n=13)}{\mathrm{AP}}$ & $\begin{array}{c}\mathrm{RV} \\
(n=8)\end{array}$ & $\underset{(n=15)}{\mathrm{AP}}$ & $\begin{array}{c}\mathrm{RV} \\
(n=9)\end{array}$ \\
\hline $\begin{array}{l}\text { Pteridium } \\
\text { aquilinum }\end{array}$ & $1.6 \pm 1.0$ & $0.0 \pm 0.0$ & $1.1 \pm 0.8$ & $0.7 \pm 0.5$ & $1.0 \pm 1.0$ & $1.3 \pm 0.9$ & $0.2 \pm 0.2$ & $0.0 \pm 0.0$ & $0.9 \pm 0.5$ & $4.7 \pm 2.3$ \\
\hline \multicolumn{11}{|l|}{ PLANTS } \\
\hline \multicolumn{11}{|l|}{ Pinaceae } \\
\hline $\begin{array}{l}\text { Tsuga canadensis } \\
\text { needles }\end{array}$ & $0.9 \pm 0.9$ & $0.8 \pm 0.5$ & $10.7 \pm 6.5$ & $0.0 \pm 0.0$ & $0.6 \pm 0.6$ & $0.0 \pm 0.0$ & $0.7 \pm 0.5$ & $0.0 \pm 0.0$ & $0.0 \pm 0.0$ & $6.6 \pm 4.2$ \\
\hline \multicolumn{11}{|l|}{ Cyperaceae } \\
\hline Carex spp. & $4.1 \pm 4.1$ & $0.0 \pm 0.0$ & $0.0 \pm 0.0$ & $0.0 \pm 0.0$ & $0.1 \pm 0.1$ & $0.0 \pm 0.0$ & $2.2 \pm 1.9$ & $0.0 \pm 0.0$ & $0.0 \pm 0.0$ & $0.9 \pm 0.7$ \\
\hline \multicolumn{11}{|l|}{ Liliaceae } \\
\hline $\begin{array}{l}\text { Smilax spp. } \\
\text { fruit/seed }\end{array}$ & $8.1 \pm 2.8$ & $3.7 \pm 2.3$ & $6.1 \pm 4.8$ & $1.3 \pm 1.1$ & $6.5 \pm 4.1$ & $1.7 \pm 1.6$ & $0.6 \pm 0.4$ & $0.0 \pm 0.0$ & $0.6 \pm 0.5$ & $0.3 \pm 0.3$ \\
\hline S. spp. leaf/stem & $0.5 \pm 0.4$ & $5.7 \pm 1.9$ & $0.4 \pm 0.4$ & $5.9 \pm 1.8$ & $2.0 \pm 1.4$ & $4.5 \pm 1.7$ & $0.0 \pm 0.0$ & $0.5 \pm 0.5$ & $0.3 \pm 0.3$ & $9.5 \pm 4.6$ \\
\hline \multicolumn{11}{|l|}{ Juglandaceae } \\
\hline Juglans nigra nut & $3.5 \pm 1.5$ & $0.0 \pm 0.0$ & $0.0 \pm 0.0$ & $0.0 \pm 0.0$ & $0.1 \pm 0.1$ & $0.0 \pm 0.0$ & $0.0 \pm 0.0$ & $0.0 \pm 0.0$ & $0.0 \pm 0.0$ & $1.3 \pm 7.1$ \\
\hline Carya spp. leaf & $0.1 \pm 0.1$ & $0.0 \pm 0.0$ & $0.0 \pm 0.0$ & $0.5 \pm 0.4$ & $0.0 \pm 0.0$ & $1.0 \pm 0.5$ & $0.0 \pm 0.0$ & $5.0 \pm 3.4$ & $0.0 \pm 0.0$ & $0.0 \pm 0.0$ \\
\hline C. spp. nut & $3.0 \pm 1.4$ & $0.0 \pm 0.0$ & $0.0 \pm 0.0$ & $0.0 \pm 0.0$ & $0.2 \pm 0.2$ & $0.0 \pm 0.0$ & $0.1 \pm 0.1$ & $0.9 \pm 0.9$ & $0.6 \pm 0.4$ & $2.7 \pm 1.3$ \\
\hline \multicolumn{11}{|l|}{ Corylaceae } \\
\hline Ostrya/Fagus leaf $^{1}$ & $0.0 \pm 0.0$ & $0.0 \pm 0.0$ & $0.0 \pm 0.0$ & $0.0 \pm 0.0$ & $2.3 \pm 1.3$ & $0.0 \pm 0.0$ & $0.0 \pm 0.0$ & $0.0 \pm 0.0$ & $0.0 \pm 0.0$ & $0.0 \pm 0.0$ \\
\hline
\end{tabular}

${ }^{1}$ Genera were pooled due to difficulty in distinguishing between similar cell structures. 


\begin{tabular}{|c|c|c|c|c|c|c|c|c|c|c|}
\hline \multirow[t]{2}{*}{ Species } & \multicolumn{2}{|c|}{$\underline{\text { Fall } 1997}$} & \multicolumn{2}{|c|}{$\underline{\text { Winter } 1998}$} & \multicolumn{2}{|c|}{ Spring 1998} & \multicolumn{2}{|c|}{$\underline{\text { Summer } 1998}$} & \multicolumn{2}{|c|}{$\underline{\text { Fall } 1998}$} \\
\hline & $\begin{array}{c}\text { AP } \\
(n=15)\end{array}$ & $\begin{array}{c}\mathrm{RV} \\
(n=11)\end{array}$ & $\begin{array}{c}\text { AP } \\
(n=12)\end{array}$ & $\begin{array}{c}\mathrm{RV} \\
(n=13)\end{array}$ & $\begin{array}{c}\mathrm{AP} \\
(n=13)\end{array}$ & $\begin{array}{c}\mathrm{RV} \\
(n=14)\end{array}$ & $\underset{(n=13)}{\mathrm{AP}}$ & $\begin{array}{c}\mathrm{RV} \\
(n=8)\end{array}$ & $\begin{array}{c}\mathrm{AP} \\
(n=15)\end{array}$ & $\begin{array}{c}\mathrm{RV} \\
(n=9)\end{array}$ \\
\hline Betula/Fagus bud & $0.0 \pm 0.0$ & $0.0 \pm 0.0$ & $0.0 \pm 0.0$ & $0.0 \pm 0.0$ & $0.0 \pm 0.0$ & $17.0 \pm 6.8$ & $0.0 \pm 0.0$ & $2.0 \pm 1.5$ & $0.0 \pm 0.0$ & $0.0 \pm 0.0$ \\
\hline B. spp leaf/stem & $0.6 \pm 0.6$ & $1.6 \pm 0.6$ & $0.4 \pm 0.4$ & $5.8 \pm 3.7$ & $3.5 \pm 1.6$ & $2.8 \pm 1.3$ & $4.5 \pm 3.7$ & $0.0 \pm 0.0$ & $1.0 \pm 0.8$ & $0.0 \pm 0.0$ \\
\hline $\begin{array}{l}\text { Alnus serrulata } \\
\text { leaf/stem }\end{array}$ & $0.2 \pm 0.2$ & $0.4 \pm 0.4$ & $0.0 \pm 0.0$ & $0.8 \pm 0.6$ & $2.9 \pm 1.5$ & $0.4 \pm 0.4$ & $0.8 \pm 0.4$ & $0.0 \pm 0.0$ & $0.0 \pm 0.0$ & $0.0 \pm 0.0$ \\
\hline \multicolumn{11}{|l|}{ Fagaceae } \\
\hline Fagus/Ostrya leaf & $0.0 \pm 0.0$ & $0.0 \pm 0.0$ & $0.0 \pm 0.0$ & $0.0 \pm 0.0$ & $2.3 \pm 1.3$ & $0.0 \pm 0.0$ & $0.0 \pm 0.0$ & $0.0 \pm 0.0$ & $0.0 \pm 0.0$ & $0.0 \pm 0.0$ \\
\hline Fagus/Betula bud & $0.0 \pm 0.0$ & $0.0 \pm 0.0$ & $0.0 \pm 0.0$ & $0.0 \pm 0.0$ & $0.0 \pm 0.0$ & $17.0 \pm 6.8$ & $0.0 \pm 0.0$ & $2.0 \pm 1.5$ & $0.0 \pm 0.0$ & $0.0 \pm 0.0$ \\
\hline Quercus spp. acorn & $2.2 \pm 1.1$ & $0.3 \pm 0.3$ & $2.2 \pm 1.2$ & $0.0 \pm 0.0$ & $0.0 \pm 0.0$ & $0.4 \pm 0.4$ & $8.6 \pm 6.5$ & $6.9 \pm 6.9$ & $24.5 \pm 7.5$ & $15.2 \pm 6.9$ \\
\hline Q. spp. leaf/stem & $0.0 \pm 0.0$ & $7.0 \pm 2.4$ & $0.3 \pm 0.3$ & $3.4 \pm 1.4$ & $0.6 \pm 0.6$ & $1.2 \pm 0.8$ & $0.5 \pm 0.5$ & $0.0 \pm 0.0$ & $0.0 \pm 0.0$ & $1.0 \pm 0.5$ \\
\hline $\begin{array}{l}Q . \text { velutinal } \\
\text { coccinea leaf }\end{array}$ & $0.0 \pm 0.0$ & $2.7 \pm 1.2$ & $0.0 \pm 0.0$ & $1.0 \pm 0.4$ & $0.5 \pm 0.3$ & $3.8 \pm 2.0$ & $0.3 \pm 0.3$ & $2.5 \pm 2.5$ & $0.2 \pm 0.2$ & $1.0 \pm 0.6$ \\
\hline \multicolumn{11}{|l|}{ Magnoliaceae } \\
\hline $\begin{array}{l}\text { Magnolia spp. } \\
\text { seed/cone }\end{array}$ & $1.6 \pm 0.6$ & $1.4 \pm 0.9$ & $0.2 \pm 0.2$ & $1.7 \pm 1.6$ & $2.5 \pm 1.0$ & $4.7 \pm 3.2$ & $0.0 \pm 0.0$ & $10.3 \pm 7.2$ & $3.8 \pm 2.0$ & $0.0 \pm 0.0$ \\
\hline M. spp. leaf & $0.0 \pm 0.0$ & $6.0 \pm 3.2$ & $0.0 \pm 0.0$ & $2.6 \pm 1.7$ & $0.0 \pm 0.0$ & $7.6 \pm 4.5$ & $0.0 \pm 0.0$ & $2.1 \pm 1.2$ & $1.1 \pm 0.8$ & $0.9 \pm 0.9$ \\
\hline \multicolumn{11}{|l|}{ Rosaceae } \\
\hline $\begin{array}{l}\text { Rubus spp. } \\
\text { fruit/seed }\end{array}$ & $4.0 \pm 3.6$ & $0.0 \pm 0.0$ & $0.4 \pm 0.4$ & $0.0 \pm 0.0$ & $0.0 \pm 0.0$ & $0.0 \pm 0.0$ & $0.3 \pm 0.2$ & $1.4 \pm 1.4$ & $2.1 \pm 1.2$ & $0.0 \pm 0.0$ \\
\hline R. spp. leaf/stem & $3.8 \pm 1.1$ & $24.6 \pm 5.8$ & $5.0 \pm 1.7$ & $13.8 \pm 3.1$ & $4.1 \pm 1.3$ & $7.1 \pm 2.4$ & $0.8 \pm 0.7$ & $11.1 \pm 6.1$ & $2.4 \pm 0.9$ & $1.7 \pm 1.7$ \\
\hline Rosa spp. leaf/stem & $0.2 \pm 0.2$ & $3.0 \pm 1.5$ & $0.0 \pm 0.0$ & $1.0 \pm 0.6$ & $0.0 \pm 0.0$ & $0.7 \pm 0.7$ & $0.0 \pm 0.0$ & $0.0 \pm 0.0$ & $0.0 \pm 0.0$ & $0.0 \pm 0.0$ \\
\hline
\end{tabular}




\begin{tabular}{|c|c|c|c|c|c|c|c|c|c|c|}
\hline \multirow[t]{2}{*}{ Species } & \multicolumn{2}{|c|}{$\underline{\text { Fall } 1997}$} & \multicolumn{2}{|c|}{$\underline{\text { Winter } 1998}$} & \multicolumn{2}{|c|}{ Spring 1998} & \multicolumn{2}{|c|}{$\underline{\text { Summer } 1998}$} & \multicolumn{2}{|c|}{$\underline{\text { Fall } 1998}$} \\
\hline & $\begin{array}{c}\text { AP } \\
(n=15)\end{array}$ & $\begin{array}{c}\mathrm{RV} \\
(n=11)\end{array}$ & $\begin{array}{c}\text { AP } \\
(n=12)\end{array}$ & $\begin{array}{c}\mathrm{RV} \\
(n=13)\end{array}$ & $\begin{array}{c}\mathrm{AP} \\
(n=13)\end{array}$ & $\begin{array}{c}\mathrm{RV} \\
(n=14)\end{array}$ & $\begin{array}{c}\text { AP } \\
(n=13)\end{array}$ & $\begin{array}{c}\mathrm{RV} \\
(n=8)\end{array}$ & $\begin{array}{c}\mathrm{AP} \\
(n=15)\end{array}$ & $\begin{array}{c}\mathrm{RV} \\
(n=9)\end{array}$ \\
\hline R. spp. seed & $0.2 \pm 0.2$ & $2.4 \pm 1.7$ & $1.5 \pm 1.0$ & $1.3 \pm 0.8$ & $1.6 \pm 0.9$ & $0.9 \pm 0.8$ & $0.0 \pm 0.0$ & $0.0 \pm 0.0$ & $1.2 \pm 1.2$ & $0.0 \pm 0.0$ \\
\hline Crataegus spp. leaf & $2.4 \pm 0.8$ & $2.2 \pm 0.9$ & $0.6 \pm 0.6$ & $2.7 \pm 0.9$ & $0.2 \pm 0.2$ & $0.6 \pm 0.6$ & $0.3 \pm 0.3$ & $0.0 \pm 0.0$ & $0.6 \pm 0.4$ & $0.0 \pm 0.0$ \\
\hline $\begin{array}{l}\text { Prunus spp. } \\
\text { leaf/stem }\end{array}$ & $0.0 \pm 0.0$ & $6.6 \pm 2.8$ & $0.9 \pm 0.8$ & $7.3 \pm 2.1$ & $2.1 \pm 1.1$ & $1.4 \pm 0.8$ & $2.8 \pm 1.6$ & $0.0 \pm 0.0$ & $0.3 \pm 0.3$ & $0.0 \pm 0.0$ \\
\hline \multicolumn{11}{|l|}{ Fabaceae } \\
\hline $\begin{array}{l}\text { Cercis canadensis } \\
\text { leaf }\end{array}$ & $1.3 \pm 0.9$ & $2.1 \pm 0.7$ & $0.4 \pm 0.4$ & $4.0 \pm 1.6$ & $1.0 \pm 0.6$ & $0.8 \pm 0.8$ & $0.2 \pm 0.2$ & $0.0 \pm 0.0$ & $0.7 \pm 0.7$ & $0.6 \pm 0.6$ \\
\hline C. canadensis pod & $0.0 \pm 0.0$ & $1.8 \pm 1.0$ & $0.0 \pm 0.0$ & $0.0 \pm 0.0$ & $0.7 \pm 0.5$ & $0.2 \pm 0.2$ & $1.5 \pm 1.0$ & $2.8 \pm 1.8$ & $0.2 \pm 0.2$ & $0.0 \pm 0.0$ \\
\hline \multicolumn{11}{|l|}{ Oxalidaceae } \\
\hline Oxalis spp. & $0.0 \pm 0.0$ & $0.1 \pm 0.1$ & $0.0 \pm 0.0$ & $2.2 \pm 2.2$ & $0.0 \pm 0.0$ & $0.0 \pm 0.0$ & $0.0 \pm 0.0$ & $0.0 \pm 0.0$ & $0.0 \pm 0.0$ & $0.0 \pm 0.0$ \\
\hline \multicolumn{11}{|l|}{ Aquifoliaceae } \\
\hline Ilex spp. fruit & $0.0 \pm 0.0$ & $0.0 \pm 0.0$ & $0.0 \pm 0.0$ & $2.0 \pm 1.0$ & $0.0 \pm 0.0$ & $2.1 \pm 1.6$ & $0.0 \pm 0.0$ & $0.0 \pm 0.0$ & $0.0 \pm 0.0$ & $0.0 \pm 0.0$ \\
\hline $\begin{array}{l}\text { Ilex/Vaccinium } \\
\text { fruit/seed }\end{array}$ & $3.2 \pm 1.1$ & $0.0 \pm 0.0$ & $6.0 \pm 2.2$ & $0.0 \pm 0.0$ & $10.0 \pm 2.8$ & $0.0 \pm 0.0$ & $14.4 \pm 7.3$ & $0.0 \pm 0.0$ & $3.9 \pm 1.7$ & $0.0 \pm 0.0$ \\
\hline \multicolumn{11}{|l|}{ Araliaceae } \\
\hline Aralia spinosa & $0.6 \pm 0.6$ & $0.2 \pm 0.2$ & $8.1 \pm 2.8$ & $0.0 \pm 0.0$ & $5.0 \pm 4.1$ & $0.0 \pm 0.0$ & $0.0 \pm 0.0$ & $0.0 \pm 0.0$ & $0.6 \pm 0.4$ & $0.0 \pm 0.0$ \\
\hline \multicolumn{11}{|l|}{ Elaeagnaceae } \\
\hline $\begin{array}{l}\text { Elaeagnus } \\
\text { umbellata leaf }\end{array}$ & $0.0 \pm 0.0$ & $0.0 \pm 0.0$ & $0.0 \pm 0.0$ & $0.0 \pm 0.0$ & $0.0 \pm 0.0$ & $0.7 \pm 0.7$ & $0.0 \pm 0.0$ & $0.3 \pm 0.3$ & $0.0 \pm 0.0$ & $3.5 \pm 3.1$ \\
\hline E. umbellata seed & $0.4 \pm 0.3$ & $0.8 \pm 0.6$ & $0.9 \pm 0.9$ & $0.0 \pm 0.0$ & $0.2 \pm 0.2$ & $2.9 \pm 1.7$ & $0.0 \pm 0.0$ & $2.0 \pm 2.0$ & $0.2 \pm 0.2$ & $0.7 \pm 0.7$ \\
\hline
\end{tabular}




\begin{tabular}{|c|c|c|c|c|c|c|c|c|c|c|}
\hline \multirow[t]{2}{*}{ Species } & \multicolumn{2}{|c|}{$\underline{\text { Fall } 1997}$} & \multicolumn{2}{|c|}{$\underline{\text { Winter } 1998}$} & \multicolumn{2}{|c|}{$\underline{\text { Spring } 1998}$} & \multicolumn{2}{|c|}{$\underline{\text { Summer } 1998}$} & \multicolumn{2}{|c|}{$\underline{\text { Fall } 1998}$} \\
\hline & $\begin{array}{c}\mathrm{AP} \\
(n=15)\end{array}$ & $\begin{array}{c}\mathrm{RV} \\
(n=11)\end{array}$ & $\underset{(n=12)}{\mathrm{AP}}$ & $\begin{array}{c}\mathrm{RV} \\
(n=13)\end{array}$ & $\begin{array}{c}\mathrm{AP} \\
(n=13)\end{array}$ & $\begin{array}{c}\mathrm{RV} \\
(n=14)\end{array}$ & $\begin{array}{c}\mathrm{AP} \\
(n=13)\end{array}$ & $\begin{array}{c}\mathrm{RV} \\
(n=8)\end{array}$ & $\underset{(n=15)}{\mathrm{AP}}$ & $\begin{array}{c}\mathrm{RV} \\
(n=9)\end{array}$ \\
\hline \multicolumn{11}{|l|}{ Cornaceae } \\
\hline Cornus spp. leaf & $0.0 \pm 0.0$ & $0.2 \pm 0.2$ & $0.3 \pm 0.3$ & $3.0 \pm 1.3$ & $0.5 \pm 0.5$ & $1.0 \pm 0.5$ & $0.7 \pm 0.7$ & $0.3 \pm 0.3$ & $0.0 \pm 0.0$ & $0.0 \pm 0.0$ \\
\hline Cornus/Ilex stem & $0.0 \pm 0.0$ & $3.9 \pm 2.2$ & $2.9 \pm 1.8$ & $2.6 \pm 1.0$ & $2.5 \pm 1.4$ & $1.3 \pm 0.8$ & $0.1 \pm 0.1$ & $1.6 \pm 1.4$ & $0.3 \pm 0.3$ & $0.0 \pm 0.0$ \\
\hline \multicolumn{11}{|l|}{ Ericaceae } \\
\hline $\begin{array}{l}\text { Rhododendron spp. } \\
\text { leaf/stem }\end{array}$ & $0.4 \pm 0.3$ & $0.0 \pm 0.0$ & $6.1 \pm 4.2$ & $0.6 \pm 0.3$ & $6.0 \pm 3.2$ & $1.5 \pm 1.1$ & $1.2 \pm 0.7$ & $0.3 \pm 0.3$ & $3.4 \pm 2.1$ & $0.3 \pm 0.3$ \\
\hline $\begin{array}{l}\text { Vaccinium spp. } \\
\text { fruit/seed }\end{array}$ & $0.0 \pm 0.0$ & $0.0 \pm 0.0$ & $0.2 \pm 0.2$ & $0.0 \pm 0.0$ & $0.0 \pm 0.0$ & $0.0 \pm 0.0$ & $0.0 \pm 0.0$ & $11.0 \pm 9.8$ & $0.0 \pm 0.0$ & $0.9 \pm 0.9$ \\
\hline V. spp. leaf/stem & $1.7 \pm 1.0$ & $0.2 \pm 0.2$ & $8.5 \pm 4.9$ & $6.0 \pm 2.2$ & $5.5 \pm 1.6$ & $0.2 \pm 0.2$ & $0.4 \pm 0.4$ & $0.0 \pm 0.0$ & $6.1 \pm 2.2$ & $0.0 \pm 0.0$ \\
\hline $\begin{array}{l}\text { Vaccinium/ } \\
\text { Rhododendron } \\
\text { stem }\end{array}$ & $0.0 \pm 0.0$ & $0.0 \pm 0.0$ & $0.9 \pm 0.9$ & $1.6 \pm 1.6$ & $0.8 \pm 0.8$ & $0.0 \pm 0.0$ & $0.0 \pm 0.0$ & $2.4 \pm 2.4$ & $0.0 \pm 0.0$ & $0.0 \pm 0.0$ \\
\hline $\begin{array}{l}\text { Vaccinium/Ilex } \\
\text { fruit/seed }\end{array}$ & $3.2 \pm 1.1$ & $0.0 \pm 0.0$ & $6.0 \pm 2.2$ & $0.0 \pm 0.0$ & $10.0 \pm 2.8$ & $0.0 \pm 0.0$ & $14.4 \pm 7.3$ & $0.0 \pm 0.0$ & $3.9+1.7$ & $0.0 \pm 0.0$ \\
\hline \multicolumn{11}{|l|}{ Caprifoliaceae } \\
\hline Viburnum spp. fruit & $1.5 \pm 0.6$ & $0.0 \pm 0.0$ & $2.3 \pm 1.2$ & $0.0 \pm 0.0$ & $3.5 \pm 1.4$ & $0.0 \pm 0.0$ & $5.8 \pm 3.2$ & $0.0 \pm 0.0$ & $0.6 \pm 0.4$ & $0.3 \pm 0.3$ \\
\hline $\begin{array}{l}\text { Sambucus nigra } \\
\text { leaf }\end{array}$ & $0.8 \pm 0.5$ & $0.7 \pm 0.7$ & $3.3 \pm 1.3$ & $1.3 \pm 1.1$ & $2.5 \pm 1.9$ & $0.2 \pm 0.2$ & $0.0 \pm 0.0$ & $2.2 \pm 1.4$ & $0.4 \pm 0.4$ & $2.2 \pm 1.5$ \\
\hline \multicolumn{11}{|l|}{ Asteraceae } \\
\hline Aster spp. & $0.0 \pm 0.0$ & $0.1 \pm 0.1$ & $0.1 \pm 0.1$ & $1.2 \pm 0.9$ & $0.4 \pm 0.3$ & $0.0 \pm 0.0$ & $0.2 \pm 0.2$ & $0.0 \pm 0.0$ & $0.0 \pm 0.0$ & $2.9 \pm 2.9$ \\
\hline
\end{tabular}




\begin{tabular}{|c|c|c|c|c|c|c|c|c|c|c|}
\hline \multirow[t]{2}{*}{ Species } & \multicolumn{2}{|c|}{$\underline{\text { Fall } 1997}$} & \multicolumn{2}{|c|}{ Winter 1998} & \multicolumn{2}{|c|}{ Spring 1998} & \multicolumn{2}{|c|}{$\underline{\text { Summer } 1998}$} & \multicolumn{2}{|c|}{$\underline{\text { Fall } 1998}$} \\
\hline & $\begin{array}{c}\mathrm{AP} \\
(n=15)\end{array}$ & $\begin{array}{c}\mathrm{RV} \\
(n=11)\end{array}$ & $\begin{array}{c}\mathrm{AP} \\
(n=12)\end{array}$ & $\begin{array}{c}\mathrm{RV} \\
(n=13)\end{array}$ & $\begin{array}{c}\text { AP } \\
(n=13)\end{array}$ & $\begin{array}{c}\mathrm{RV} \\
(n=14)\end{array}$ & $\begin{array}{c}\text { AP } \\
(n=13)\end{array}$ & $\begin{array}{c}\mathrm{RV} \\
(n=8)\end{array}$ & $\underset{(n=15)}{\mathrm{AP}}$ & $\begin{array}{c}\mathrm{RV} \\
(n=9)\end{array}$ \\
\hline $\begin{array}{l}\text { Prenanthes spp. } \\
\text { Flower/seed }\end{array}$ & $0.0 \pm 0.0$ & $3.5 \pm 2.0$ & $0.0 \pm 0.0$ & $0.1 \pm 0.1$ & $0.0 \pm 0.0$ & $0.2 \pm 0.2$ & $0.0 \pm 0.0$ & $0.0 \pm 0.0$ & $0.0 \pm 0.0$ & $1.9 \pm 1.8$ \\
\hline \multicolumn{11}{|l|}{ Miscellaneous plants } \\
\hline Unknown flower & $0.0 \pm 0.0$ & $0.0 \pm 0.0$ & $0.0 \pm 0.0$ & $0.0 \pm 0.0$ & $0.0 \pm 0.0$ & $0.0 \pm 0.0$ & $0.4 \pm 0.4$ & $5.2 \pm 5.2$ & $0.0 \pm 0.0$ & $0.0 \pm 0.0$ \\
\hline Unknown leaf/stem & $0.0 \pm 0.0$ & $0.3 \pm 0.3$ & $0.0 \pm 0.0$ & $0.5 \pm 0.4$ & $2.3 \pm 1.0$ & $0.0 \pm 0.0$ & $0.5 \pm 0.4$ & $8.0 \pm 8.0$ & $0.2 \pm 0.2$ & $0.0 \pm 0.0$ \\
\hline Unknown nut/seed & $2.0 \pm 1.1$ & $0.5 \pm 0.5$ & $0.2 \pm 0.2$ & $1.2 \pm 1.2$ & $1.6 \pm 1.0$ & $0.5 \pm 0.4$ & $0.0 \pm 0.0$ & $0.0 \pm 0.0$ & $0.6 \pm 0.6$ & $1.4 \pm 1.0$ \\
\hline Unknown shrub & $0.6 \pm 0.4$ & $2.9 \pm 0.9$ & $2.2 \pm 0.8$ & $3.1 \pm 0.6$ & $1.5 \pm 0.6$ & $2.1 \pm 0.8$ & $0.8 \pm 0.4$ & $0.7 \pm 0.7$ & $1.0 \pm 0.4$ & $0.9 \pm 0.6$ \\
\hline \multicolumn{11}{|l|}{ Mosses } \\
\hline Unknown moss & $0.3 \pm 0.2$ & $0.0 \pm 0.0$ & $0.0 \pm 0.0$ & $0.0 \pm 0.0$ & $0.6 \pm 0.3$ & $0.0 \pm 0.0$ & $0.4 \pm 0.2$ & $1.0 \pm 1.0$ & $0.5 \pm 0.3$ & $3.4 \pm 2.3$ \\
\hline \multicolumn{11}{|l|}{ Lichens } \\
\hline Unknown lichen & $4.5 \pm 1.2$ & $0.0 \pm 0.0$ & $1.05 \pm 0.6$ & $0.0 \pm 0.0$ & $4.6 \pm 2.2$ & $0.0 \pm 0.0$ & $22.0 \pm 6.2$ & $0.5 \pm 0.5$ & $1.2 \pm 0.8$ & $0.3 \pm 0.2$ \\
\hline
\end{tabular}


APPENDIX C

FOOD ITMES THAT COMPOSED > 2\% OF THE TOTAL DIET OF MALE AND FEMALE ALLEGHENY WOODRATS IN ANY SEASON FROM NOVEMBER 1997- DECEMBER 1998 IN THE RIDGE AND VALLEY PHYSIOGRAPHIC PROVINCE OF OF VIRGINIA AND WEST VIRGINIA 
Appendix C. Food items that composed $>2 \%$ of the total diet of male and female Allegheny woodrats in any season from November 1997 through December 1998 in the Ridge and Valley Physiographic Province of West Virginia and Virginia. Expressed as percent of the total diet \pm (SE). Taxonomy of the vascular plants follows Strausbaugh and Core (1977) and fungi following Lincoff and Knopf (1988).

\begin{tabular}{|c|c|c|c|c|c|c|c|c|c|c|}
\hline \multirow[t]{2}{*}{ Species } & \multicolumn{2}{|c|}{$\underline{\text { Fall } 1997}$} & \multicolumn{2}{|c|}{$\underline{\text { Winter } 1998}$} & \multicolumn{2}{|c|}{ Spring 1998} & \multicolumn{2}{|c|}{$\underline{\text { Summer } 1998}$} & \multicolumn{2}{|c|}{$\underline{\text { Fall } 1998}$} \\
\hline & $\begin{array}{l}\text { Male } \\
(n=2)\end{array}$ & $\begin{array}{c}\text { Female } \\
(n=9)\end{array}$ & $\begin{array}{l}\text { Male } \\
(n=3)\end{array}$ & $\begin{array}{l}\text { Female } \\
(n=10)\end{array}$ & $\begin{array}{l}\text { Male } \\
(n=2)\end{array}$ & $\begin{array}{l}\text { Female } \\
(n=12)\end{array}$ & $\begin{array}{l}\text { Male } \\
(n=2)\end{array}$ & $\begin{array}{c}\text { Female } \\
(n=6)\end{array}$ & $\begin{array}{l}\text { Male } \\
(n=4)\end{array}$ & $\begin{array}{c}\text { Female } \\
(n=5)\end{array}$ \\
\hline \multicolumn{11}{|l|}{ FUNGI } \\
\hline Unknown fungi & $0.0 \pm 0.0$ & $0.5 \pm 0.5$ & $1.7 \pm 1.7$ & $0.0 \pm 0.0$ & $11.2 \pm 4.5$ & $11.3 \pm 4.4$ & $0.0 \pm 0.0$ & $1.5 \pm 1.0$ & $0.0 \pm 0.0$ & $3.5 \pm 3.5$ \\
\hline \multicolumn{11}{|l|}{ Gautieriaceae } \\
\hline $\begin{array}{l}\text { Gautieria } \\
\text { morchelliformis }\end{array}$ & $0.0 \pm 0.0$ & $0.0 \pm 0.0$ & $0.0 \pm 0.0$ & $0.0 \pm 0.0$ & $0.0 \pm 0.0$ & $0.0 \pm 0.0$ & $0.0 \pm 0.0$ & $0.0 \pm 0.0$ & $0.0 \pm 0.0$ & $0.0 \pm 0.0$ \\
\hline $\begin{array}{l}\text { Unknown } \\
\text { Puffball fungi }\end{array}$ & $0.0 \pm 0.0$ & $0.0 \pm 0.0$ & $0.0 \pm 0.0$ & $0.0 \pm 0.0$ & $0.0 \pm 0.0$ & $0.0 \pm 0.0$ & $0.0 \pm 0.0$ & $1.5 \pm 1.5$ & $1.7 \pm 1.7$ & $6.2 \pm 6.2$ \\
\hline \multicolumn{11}{|l|}{ Polyporaceae } \\
\hline $\begin{array}{l}\text { Unknown } \\
\text { polypore }\end{array}$ & $0.0 \pm 0.0$ & $0.0 \pm 0.0$ & $0.0 \pm 0.0$ & $1.0 \pm 1.0$ & $1.0 \pm 1.0$ & $2.2 \pm 0.7$ & $3.7 \pm 3.7$ & $0.0 \pm 0.0$ & $0.0 \pm 0.0$ & $3.6 \pm 3.1$ \\
\hline \multicolumn{11}{|l|}{ FERNS } \\
\hline \multicolumn{11}{|l|}{ Polypodiaceae } \\
\hline $\begin{array}{l}\text { Dryopteris } \\
\text { marginalis }\end{array}$ & $0.0 \pm 0.0$ & $3.0 \pm 2.1$ & $13.9 \pm 12.6$ & $11.1 \pm 6.7$ & $0.0 \pm 0.0$ & $2.3 \pm 2.2$ & $0.0 \pm 0.0$ & $0.0 \pm 0.0$ & $6.1 \pm 6.1$ & $0.0 \pm 0.0$ \\
\hline $\begin{array}{l}\text { Pteridium } \\
\text { aquilinum }\end{array}$ & $0.0 \pm 0.0$ & $0.0 \pm 0.0$ & $2.3 \pm 2.3$ & $0.2 \pm 0.2$ & $0.0 \pm 0.0$ & $1.5 \pm 1.1$ & $0.0 \pm 0.0$ & $0.0 \pm 0.0$ & $6.2 \pm 4.8$ & $3.5 \pm 2.3$ \\
\hline \multicolumn{11}{|l|}{ PLANTS } \\
\hline Pinaceae & & & & & & & & & & \\
\hline
\end{tabular}




\begin{tabular}{|c|c|c|c|c|c|c|c|c|c|c|}
\hline \multirow[t]{2}{*}{ Species } & \multicolumn{2}{|c|}{$\underline{\text { Fall } 1997}$} & \multicolumn{2}{|c|}{$\underline{\text { Winter } 1998}$} & \multicolumn{2}{|c|}{ Spring 1998} & \multicolumn{2}{|c|}{$\underline{\text { Summer } 1998}$} & \multicolumn{2}{|c|}{$\underline{\text { Fall } 1998}$} \\
\hline & $\begin{array}{l}\text { Male } \\
(n=2)\end{array}$ & $\begin{array}{c}\text { Female } \\
(n=9)\end{array}$ & $\begin{array}{l}\text { Male } \\
(n=3)\end{array}$ & $\begin{array}{l}\text { Female } \\
(n=10)\end{array}$ & $\begin{array}{l}\text { Male } \\
(n=2)\end{array}$ & $\begin{array}{l}\text { Female } \\
(n=12)\end{array}$ & $\begin{array}{l}\text { Male } \\
(n=2)\end{array}$ & $\begin{array}{c}\text { Female } \\
(n=6)\end{array}$ & $\begin{array}{l}\text { Male } \\
(n=4)\end{array}$ & $\begin{array}{l}\text { Female } \\
(n=5)\end{array}$ \\
\hline $\begin{array}{l}\text { Tsuga } \\
\text { canadensis } \\
\text { needles }\end{array}$ & $0.0 \pm 0.0$ & $1.0 \pm 0.7$ & $0.0 \pm 0.0$ & $0.0 \pm 0.0$ & $0.0 \pm 0.0$ & $0.0 \pm 0.0$ & $0.0 \pm 0.0$ & $0.0 \pm 0.0$ & $9.1 \pm 9.1$ & $4.6 \pm 3.2$ \\
\hline \multicolumn{11}{|l|}{ Cyperaceae } \\
\hline Carex spp. & $0.0 \pm 0.0$ & $0.0 \pm 0.0$ & $0.0 \pm 0.0$ & $0.0 \pm 0.0$ & $0.0 \pm 0.0$ & $0.0 \pm 0.0$ & $0.0 \pm 0.0$ & $0.0 \pm 0.0$ & $2.0 \pm 1.4$ & $0.0 \pm 0.0$ \\
\hline \multicolumn{11}{|l|}{ Liliaceae } \\
\hline $\begin{array}{l}\text { Smilax spp. } \\
\text { fruit/seed }\end{array}$ & $13.0 \pm 13.0$ & $1.7 \pm 0.9$ & $0.0 \pm 0.0$ & $1.8 \pm 1.5$ & $0.0 \pm 0.0$ & $1.9 \pm 1.8$ & $0.0 \pm 0.0$ & $0.0 \pm 0.0$ & $0.0 \pm 0.0$ & $0.5 \pm 0.5$ \\
\hline S. spp. leaf/stem & $2.5 \pm 2.5$ & $6.4 \pm 2.2$ & $12.1 \pm 6.5$ & $4.0 \pm 1.1$ & $7.4 \pm 7.4$ & $4.1 \pm 1.8$ & $2.0 \pm 2.0$ & $0.0 \pm 0.0$ & $3.5 \pm 1.2$ & $14.3 \pm 8.0$ \\
\hline \multicolumn{11}{|l|}{ Juglandaceae } \\
\hline J. nigra nut & $0.0 \pm 0.0$ & $0.0 \pm 0.0$ & $0.0 \pm 0.0$ & $0.0 \pm 0.0$ & $0.0 \pm 0.0$ & $0.0 \pm 0.0$ & $0.0 \pm 0.0$ & $0.0 \pm 0.0$ & $0.5 \pm 0.5$ & $2.2 \pm 2.2$ \\
\hline Carya spp. leaf & $0.0 \pm 0.0$ & $0.0 \pm 0.0$ & $0.0 \pm 0.0$ & $0.7 \pm 0.5$ & $1.2 \pm 1.2$ & $1.0 \pm 0.5$ & $2.3 \pm 1.6$ & $5.9 \pm 4.6$ & $0.0 \pm 0.0$ & $0.0 \pm 0.0$ \\
\hline$C$. spp. nut & $0.0 \pm 0.0$ & $0.0 \pm 0.0$ & $0.0 \pm 0.0$ & $0.0 \pm 0.0$ & $0.0 \pm 0.0$ & $0.0 \pm 0.0$ & $0.0 \pm 0.0$ & $1.2 \pm 1.2$ & $2.3 \pm 2.3$ & $2.9 \pm 1.8$ \\
\hline \multicolumn{11}{|l|}{ Corylaceae } \\
\hline $\begin{array}{l}\text { Ostrya/Fagus } \\
\text { leaf }^{1}\end{array}$ & $0.0 \pm 0.0$ & $0.0 \pm 0.0$ & $0.0 \pm 0.0$ & $0.0 \pm 0.0$ & $0.0 \pm 0.0$ & $0.0 \pm 0.0$ & $0.0 \pm 0.0$ & $0.0 \pm 0.0$ & $0.0 \pm 0.0$ & $0.0 \pm 0.0$ \\
\hline B. spp leaf/stem & $0.0 \pm 0.0$ & $2.0 \pm 0.7$ & $2.8 \pm 1.7$ & $6.7 \pm 4.8$ & $10.8 \pm 4.1$ & $1.4 \pm 0.9$ & $0.0 \pm 0.0$ & $0.0 \pm 0.0$ & $0.0 \pm 0.0$ & $0.0 \pm 0.0$ \\
\hline $\begin{array}{l}\text { Betula/Fagus } \\
\text { bud }\end{array}$ & $0.0 \pm 0.0$ & $0.0 \pm 0.0$ & $0.0 \pm 0.0$ & $0.0 \pm 0.0$ & $34.4 \pm 20.6$ & $14.1 \pm 7.3$ & $6.0 \pm 6.0$ & $0.6 \pm 0.6$ & $0.0 \pm 0.0$ & $0.0 \pm 0.0$ \\
\hline
\end{tabular}

${ }^{1}$ Genera were pooled due to difficulty in distinguishing between similar cell structures. 


\begin{tabular}{|c|c|c|c|c|c|c|c|c|c|c|}
\hline \multirow[t]{2}{*}{ Species } & \multicolumn{2}{|c|}{$\underline{\text { Fall } 1997}$} & \multicolumn{2}{|c|}{$\underline{\text { Winter } 1998}$} & \multicolumn{2}{|c|}{ Spring 1998} & \multicolumn{2}{|c|}{$\underline{\text { Summer } 1998}$} & \multicolumn{2}{|c|}{$\underline{\text { Fall } 1998}$} \\
\hline & $\begin{array}{l}\text { Male } \\
(n=2)\end{array}$ & $\begin{array}{c}\text { Female } \\
(n=9)\end{array}$ & $\begin{array}{l}\text { Male } \\
(n=3)\end{array}$ & $\begin{array}{l}\text { Female } \\
(n=10)\end{array}$ & $\begin{array}{l}\text { Male } \\
(n=2)\end{array}$ & $\begin{array}{l}\text { Female } \\
(n=12)\end{array}$ & $\begin{array}{l}\text { Male } \\
(n=2)\end{array}$ & $\begin{array}{c}\text { Female } \\
(n=6)\end{array}$ & $\begin{array}{l}\text { Male } \\
(n=4)\end{array}$ & $\begin{array}{c}\text { Female } \\
(n=5)\end{array}$ \\
\hline $\begin{array}{l}\text { Alnus serrulata } \\
\text { leaf/stem }\end{array}$ & $0.0 \pm 0.0$ & $0.4 \pm 0.4$ & $0.8 \pm 0.8$ & $0.8 \pm 0.8$ & $0.0 \pm 0.0$ & $0.5 \pm 0.5$ & $0.0 \pm 0.0$ & $0.0 \pm 0.0$ & $0.0 \pm 0.0$ & $0.0 \pm 0.0$ \\
\hline \multicolumn{11}{|l|}{ Fagaceae } \\
\hline $\begin{array}{l}\text { Fagus/Ostrya } \\
\text { leaf }\end{array}$ & $0.0 \pm 0.0$ & $0.0 \pm 0.0$ & $0.0 \pm 0.0$ & $0.0 \pm 0.0$ & $0.0 \pm 0.0$ & $0.0 \pm 0.0$ & $0.0 \pm 0.0$ & $0.0 \pm 0.0$ & $0.0 \pm 0.0$ & $0.0 \pm 0.0$ \\
\hline $\begin{array}{l}\text { Fagus/Betula } \\
\text { bud }\end{array}$ & $0.0 \pm 0.0$ & $0.0 \pm 0.0$ & $0.0 \pm 0.0$ & $0.0 \pm 0.0$ & $34.4 \pm 20.6$ & $14.1 \pm 7.3$ & $0.0 \pm 0.0$ & $0.6 \pm 0.6$ & $0.0 \pm 0.0$ & $0.0 \pm 0.0$ \\
\hline $\begin{array}{l}\text { Quercus spp. } \\
\text { acorn }\end{array}$ & $1.9 \pm 1.9$ & $0.0 \pm 0.0$ & $0.0 \pm 0.0$ & $0.0 \pm 0.0$ & $0.0 \pm 0.0$ & $0.5 \pm 0.5$ & $0.0 \pm 0.0$ & $9.2 \pm 9.2$ & $26.8 \pm 13.3$ & $5.7 \pm 4.0$ \\
\hline Q. spp. leaf/stem & $14.3 \pm 1.8$ & $5.4 \pm 2.6$ & $6.2 \pm 5.0$ & $2.6 \pm 1.2$ & $0.0 \pm 0.0$ & $1.5 \pm 0.9$ & $0.0 \pm 0.0$ & $0.0 \pm 0.0$ & $1.3 \pm 0.8$ & $0.7 \pm 0.7$ \\
\hline $\begin{array}{l}Q . \text { velutinal } \\
\text { coccinea leaf }\end{array}$ & $6.1 \pm 6.1$ & $1.9 \pm 0.9$ & $0.8 \pm 0.8$ & $1.0 \pm 0.5$ & $1.2 \pm 1.2$ & $4.2 \pm 2.3$ & $10.1 \pm 10.1$ & $0.0 \pm 0.0$ & $0.0 \pm 0.0$ & $1.8 \pm 1.0$ \\
\hline \multicolumn{11}{|l|}{ Magnoliaceae } \\
\hline $\begin{array}{l}\text { Magnolia spp. } \\
\text { seed/cone }\end{array}$ & $0.0 \pm 0.0$ & $1.7 \pm 1.1$ & $0.0 \pm 0.0$ & $2.2 \pm 2.0$ & $0.0 \pm 0.0$ & $5.5 \pm 3.7$ & $3.0 \pm 3.0$ & $12.6 \pm 9.6$ & $0.0 \pm 0.0$ & $0.0 \pm 0.0$ \\
\hline$M$. spp. leaf & $0.0 \pm 0.0$ & $7.3 \pm 3.8$ & $0.0 \pm 0.0$ & $3.3 \pm 2.1$ & $0.6 \pm 0.6$ & $8.7 \pm 5.2$ & $1.0 \pm 1.0$ & $2.4 \pm 1.5$ & $2.1 \pm 2.1$ & $0.0 \pm 0.0$ \\
\hline \multicolumn{11}{|l|}{ Rosaceae } \\
\hline $\begin{array}{l}\text { Rubus spp. } \\
\text { fruit/seed }\end{array}$ & $0.0 \pm 0.0$ & $0.0 \pm 0.0$ & $0.0 \pm 0.0$ & $0.0 \pm 0.0$ & $0.0 \pm 0.0$ & $0.0 \pm 0.0$ & $0.0 \pm 0.0$ & $1.9 \pm 1.9$ & $0.0 \pm 0.0$ & $0.0 \pm 0.0$ \\
\hline$R$. spp. leaf/stem & $37.3 \pm 20.2$ & $21.8 \pm 5.9$ & $7.6 \pm 3.8$ & $15.7 \pm 3.7$ & $3.5 \pm 2.8$ & $7.7 \pm 2.7$ & $7.1 \pm 7.1$ & $12.4 \pm 8.1$ & $0.0 \pm 0.0$ & $3.1 \pm 3.1$ \\
\hline
\end{tabular}




\begin{tabular}{|c|c|c|c|c|c|c|c|c|c|c|}
\hline \multirow[t]{2}{*}{ Species } & \multicolumn{2}{|c|}{$\underline{\text { Fall } 1997}$} & \multicolumn{2}{|c|}{$\underline{\text { Winter } 1998}$} & \multicolumn{2}{|c|}{ Spring 1998} & \multicolumn{2}{|c|}{$\underline{\text { Summer } 1998}$} & \multicolumn{2}{|c|}{$\underline{\text { Fall } 1998}$} \\
\hline & $\begin{array}{l}\text { Male } \\
(n=2)\end{array}$ & $\begin{array}{c}\text { Female } \\
(n=9)\end{array}$ & $\begin{array}{l}\text { Male } \\
(n=3)\end{array}$ & $\begin{array}{c}\text { Female } \\
(n=10)\end{array}$ & $\begin{array}{l}\text { Male } \\
(n=2)\end{array}$ & $\begin{array}{l}\text { Female } \\
(n=12)\end{array}$ & $\begin{array}{l}\text { Male } \\
(n=2)\end{array}$ & $\begin{array}{c}\text { Female } \\
(n=6)\end{array}$ & $\begin{array}{l}\text { Male } \\
(n=4)\end{array}$ & $\begin{array}{c}\text { Female } \\
(n=5)\end{array}$ \\
\hline $\begin{array}{l}\text { Rosa spp. } \\
\text { leaf/stem }\end{array}$ & $0.0 \pm 0.0$ & $3.6 \pm 1.8$ & $0.0 \pm 0.0$ & $1.3 \pm 0.8$ & $0.0 \pm 0.0$ & $0.8 \pm 0.8$ & $0.0 \pm 0.0$ & $0.0 \pm 0.0$ & $0.0 \pm 0.0$ & $0.0 \pm 0.0$ \\
\hline$R$. spp. seed & $0.0 \pm 0.0$ & $2.9 \pm 2.0$ & $1.1 \pm 1.1$ & $1.4 \pm 1.1$ & $0.0 \pm 0.0$ & $1.1 \pm 0.7$ & $0.0 \pm 0.0$ & $0.0 \pm 0.0$ & $0.0 \pm 0.0$ & $0.0 \pm 0.0$ \\
\hline $\begin{array}{l}\text { Crataegus spp. } \\
\text { leaf }\end{array}$ & $0.0 \pm 0.0$ & $2.6 \pm 1.0$ & $4.2 \pm 1.7$ & $2.4 \pm 1.2$ & $0.0 \pm 0.0$ & $0.8 \pm 0.8$ & $0.0 \pm 0.0$ & $0.0 \pm 0.0$ & $0.0 \pm 0.0$ & $0.0 \pm 0.0$ \\
\hline $\begin{array}{l}\text { Prunus spp. } \\
\text { leaf/stem }\end{array}$ & $3.1 \pm 3.1$ & $7.4 \pm 3.4$ & $9.7 \pm 2.1$ & $6.6 \pm 2.7$ & $0.0 \pm 0.0$ & $1.6 \pm 0.9$ & $0.0 \pm 0.0$ & $0.0 \pm 0.0$ & $0.0 \pm 0.0$ & $0.0 \pm 0.0$ \\
\hline \multicolumn{11}{|l|}{ Fabaceae } \\
\hline $\begin{array}{l}\text { Cercis } \\
\text { canadensis leaf }\end{array}$ & $1.9 \pm 1.9$ & $2.1 \pm 0.9$ & $1.9 \pm 1.9$ & $4.6 \pm 2.0$ & $0.0 \pm 0.0$ & $0.9 \pm 0.9$ & $0.0 \pm 0.0$ & $0.0 \pm 0.0$ & $0.0 \pm 0.0$ & $1.1 \pm 1.1$ \\
\hline $\begin{array}{l}\text { C. canadensis } \\
\text { pod }\end{array}$ & $0.0 \pm 0.0$ & $2.2 \pm 1.2$ & $0.0 \pm 0.0$ & $0.0 \pm 0.0$ & $0.0 \pm 0.0$ & $0.3 \pm 0.3$ & $0.0 \pm 0.0$ & $3.7 \pm 2.4$ & $0.0 \pm 0.0$ & $0.0 \pm 0.0$ \\
\hline \multicolumn{11}{|l|}{ Oxalidaceae } \\
\hline Oxalis spp. & $0.0 \pm 0.0$ & $0.1 \pm 0.1$ & $9.7 \pm 9.7$ & $0.0 \pm 0.0$ & $0.0 \pm 0.0$ & $0.0 \pm 0.0$ & $0.0 \pm 0.0$ & $0.0 \pm 0.0$ & $0.0 \pm 0.0$ & $0.0 \pm 0.0$ \\
\hline \multicolumn{11}{|l|}{ Aquifoliaceae } \\
\hline Ilex spp. fruit & $0.0 \pm 0.0$ & $0.0 \pm 0.0$ & $2.1 \pm 2.1$ & $2.0 \pm 1.3$ & $0.0 \pm 0.0$ & $2.4 \pm 1.8$ & $0.0 \pm 0.0$ & $0.0 \pm 0.0$ & $0.0 \pm 0.0$ & $0.0 \pm 0.0$ \\
\hline $\begin{array}{l}\text { Ilex/Vaccinium } \\
\text { fruit/seed }\end{array}$ & $0.0 \pm 0.0$ & $0.0 \pm 0.0$ & $0.0 \pm 0.0$ & $0.0 \pm 0.0$ & $0.0 \pm 0.0$ & $0.0 \pm 0.0$ & $0.0 \pm 0.0$ & $0.0 \pm 0.0$ & $0.0 \pm 0.0$ & $0.0 \pm 0.0$ \\
\hline Araliaceae & & & & & & & & & & \\
\hline Aralia spinosa & $1.2 \pm 1.2$ & $0.0 \pm 0.0$ & $0.0 \pm 0.0$ & $0.0 \pm 0.0$ & $0.0 \pm 0.0$ & $0.0 \pm 0.0$ & $0.0 \pm 0.0$ & $0.0 \pm 0.0$ & $0.0 \pm 0.0$ & $0.0 \pm 0.0$ \\
\hline Elaeagnaceae & & & & & & & & & & \\
\hline
\end{tabular}




\begin{tabular}{|c|c|c|c|c|c|c|c|c|c|c|}
\hline \multirow[t]{2}{*}{ Species } & \multicolumn{2}{|c|}{$\underline{\text { Fall } 1997}$} & \multicolumn{2}{|c|}{$\underline{\text { Winter } 1998}$} & \multicolumn{2}{|c|}{$\underline{\text { Spring } 1998}$} & \multicolumn{2}{|c|}{$\underline{\text { Summer } 1998}$} & \multicolumn{2}{|c|}{$\underline{\text { Fall } 1998}$} \\
\hline & $\begin{array}{l}\text { Male } \\
(n=2)\end{array}$ & $\begin{array}{l}\text { Female } \\
(n=9)\end{array}$ & $\begin{array}{l}\text { Male } \\
(n=3)\end{array}$ & $\begin{array}{l}\text { Female } \\
(n=10)\end{array}$ & $\begin{array}{l}\text { Male } \\
(n=2)\end{array}$ & $\begin{array}{l}\text { Female } \\
(n=12)\end{array}$ & $\begin{array}{l}\text { Male } \\
(n=2)\end{array}$ & $\begin{array}{c}\text { Female } \\
(n=6)\end{array}$ & $\begin{array}{l}\text { Male } \\
(n=4)\end{array}$ & $\begin{array}{c}\text { Female } \\
(n=5)\end{array}$ \\
\hline $\begin{array}{l}\text { Elaeagnus } \\
\text { umbellata leaf }\end{array}$ & $0.0 \pm 0.0$ & $0.0 \pm 0.0$ & $0.0 \pm 0.0$ & $0.0 \pm 0.0$ & $0.0 \pm 0.0$ & $0.8 \pm 0.8$ & $0.0 \pm 0.0$ & $0.4 \pm 0.4$ & $0.0 \pm 0.0$ & $6.3 \pm 5.6$ \\
\hline $\begin{array}{l}\text { E. umbellata } \\
\text { seed }\end{array}$ & $0.0 \pm 0.0$ & $1.0 \pm 0.7$ & $0.0 \pm 0.0$ & $0.0 \pm 0.0$ & $10.0 \pm 10.0$ & $1.7 \pm 1.2$ & $0.0 \pm 0.0$ & $2.6 \pm 2.6$ & $1.5 \pm 1.5$ & $0.0 \pm 0.0$ \\
\hline \multicolumn{11}{|l|}{ Cornaceae } \\
\hline Cornus spp. leaf & $0.0 \pm 0.0$ & $0.3 \pm 0.3$ & $2.5 \pm 2.5$ & $3.4 \pm 1.7$ & $0.0 \pm 0.0$ & $1.2 \pm 0.6$ & $0.0 \pm 0.0$ & $0.4 \pm 0.4$ & $0.0 \pm 0.0$ & $0.0 \pm 0.0$ \\
\hline $\begin{array}{l}\text { Cornus/Ilex } \\
\text { stem }\end{array}$ & $1.8 \pm 1.8$ & $4.3 \pm 2.7$ & $1.7 \pm 1.7$ & $2.9 \pm 1.3$ & $0.0 \pm 0.0$ & $1.6 \pm 0.9$ & $1.0 \pm 1.0$ & $1.8 \pm 1.8$ & $0.0 \pm 0.0$ & $0.0 \pm 0.0$ \\
\hline \multicolumn{11}{|l|}{ Ericaceae } \\
\hline $\begin{array}{l}\text { Rhododendron } \\
\text { spp. leaf/stem }\end{array}$ & $0.0 \pm 0.0$ & $0.0 \pm 0.0$ & $1.4 \pm 1.4$ & $0.3 \pm 0.2$ & $0.0 \pm 0.0$ & $1.7 \pm 1.2$ & $2.2 \pm 2.2$ & $0.0 \pm 0.0$ & $0.0 \pm 0.0$ & $0.0 \pm 0.0$ \\
\hline $\begin{array}{l}\text { Vaccinium spp. } \\
\text { fruit/seed }\end{array}$ & $0.0 \pm 0.0$ & $0.0 \pm 0.0$ & $0.0 \pm 0.0$ & $0.0 \pm 0.0$ & $0.0 \pm 0.0$ & $0.0 \pm 0.0$ & $3.7 \pm 3.7$ & $12.2 \pm 11.5$ & $2.0 \pm 2.0$ & $0.0 \pm 0.0$ \\
\hline$V$. spp. leaf/stem & $0.0 \pm 0.0$ & $0.2 \pm 0.2$ & $1.7 \pm 1.7$ & $7.3 \pm 2.8$ & $1.2 \pm 1.2$ & $0.0 \pm 0.0$ & $0.0 \pm 0.0$ & $0.0 \pm 0.0$ & $0.0 \pm 0.0$ & $0.0 \pm 0.0$ \\
\hline $\begin{array}{l}\text { Vaccinium/ } \\
\text { Rhododendron } \\
\text { stem }\end{array}$ & $0.0 \pm 0.0$ & $0.0 \pm 0.0$ & $0.0 \pm 0.0$ & $2.1 \pm 2.1$ & $0.0 \pm 0.0$ & $0.0 \pm 0.0$ & $0.0 \pm 0.0$ & $3.2 \pm 3.2$ & $0.0 \pm 0.0$ & $0.0 \pm 0.0$ \\
\hline $\begin{array}{l}\text { Vaccinium/Ilex } \\
\text { fruit/seed }\end{array}$ & $0.0 \pm 0.0$ & $0.0 \pm 0.0$ & $0.0 \pm 0.0$ & $0.0 \pm 0.0$ & $0.0 \pm 0.0$ & $0.0 \pm 0.0$ & $0.0 \pm 0.0$ & $0.0 \pm 0.0$ & $0.0 \pm 0.0$ & $0.0 \pm 0.0$ \\
\hline \multicolumn{11}{|l|}{ Caprifoliaceae } \\
\hline $\begin{array}{l}\text { Viburnum spp. } \\
\text { fruit }\end{array}$ & $0.0 \pm 0.0$ & $0.0 \pm 0.0$ & $0.0 \pm 0.0$ & $0.0 \pm 0.0$ & $0.0 \pm 0.0$ & $0.0 \pm 0.0$ & $0.0 \pm 0.0$ & $0.0 \pm 0.0$ & $0.0 \pm 0.0$ & $0.6 \pm 0.6$ \\
\hline
\end{tabular}




\begin{tabular}{|c|c|c|c|c|c|c|c|c|c|c|}
\hline \multirow[t]{2}{*}{ Species } & \multicolumn{2}{|c|}{$\underline{\text { Fall } 1997}$} & \multicolumn{2}{|c|}{ Winter 1998} & \multicolumn{2}{|c|}{$\underline{\text { Spring } 1998}$} & \multicolumn{2}{|c|}{$\underline{\text { Summer } 1998}$} & \multicolumn{2}{|c|}{$\underline{\text { Fall } 1998}$} \\
\hline & $\begin{array}{l}\text { Male } \\
(n=2)\end{array}$ & $\begin{array}{c}\text { Female } \\
(n=9)\end{array}$ & $\begin{array}{l}\text { Male } \\
(n=3)\end{array}$ & $\begin{array}{l}\text { Female } \\
(n=10)\end{array}$ & $\begin{array}{l}\text { Male } \\
(n=2)\end{array}$ & $\begin{array}{l}\text { Female } \\
(n=12)\end{array}$ & $\begin{array}{l}\text { Male } \\
(n=2)\end{array}$ & $\begin{array}{c}\text { Female } \\
(n=6)\end{array}$ & $\begin{array}{l}\text { Male } \\
(n=4)\end{array}$ & $\begin{array}{c}\text { Female } \\
(n=5)\end{array}$ \\
\hline $\begin{array}{l}\text { Sambucus nigra } \\
\text { leaf }\end{array}$ & $0.0 \pm 0.0$ & $0.9 \pm 0.9$ & $4.6 \pm 4.6$ & $0.3 \pm 0.3$ & $0.0 \pm 0.0$ & $0.2 \pm 0.2$ & $5.1 \pm 5.1$ & $1.2 \pm 1.2$ & $2.3 \pm 2.3$ & $2.1 \pm 2.1$ \\
\hline \multicolumn{11}{|l|}{ Asteraceae } \\
\hline Aster spp. & $0.0 \pm 0.0$ & $0.1 \pm 0.1$ & $0.0 \pm 0.0$ & $1.6 \pm 1.2$ & $0.0 \pm 0.0$ & $0.0 \pm 0.0$ & $0.0 \pm 0.0$ & $0.0 \pm 0.0$ & $6.5 \pm 6.5$ & $0.0 \pm 0.0$ \\
\hline $\begin{array}{l}\text { Prenanthes spp. } \\
\text { Flower/seed }\end{array}$ & $11.0 \pm 11.0$ & $1.8 \pm 1.8$ & $0.0 \pm 0.0$ & $0.1 \pm 0.1$ & $0.0 \pm 0.0$ & $0.3 \pm 0.3$ & $0.0 \pm 0.0$ & $0.0 \pm 0.0$ & $0.4 \pm 0.4$ & $3.2 \pm 3.2$ \\
\hline \multicolumn{11}{|l|}{ Miscellaneous plants } \\
\hline Unknown flower & $0.0 \pm 0.0$ & $0.0 \pm 0.0$ & $0.0 \pm 0.0$ & $0.0 \pm 0.0$ & $0.0 \pm 0.0$ & $0.0 \pm 0.0$ & $0.0 \pm 0.0$ & $6.9 \pm 6.9$ & $0.0 \pm 0.0$ & $0.0 \pm 0.0$ \\
\hline $\begin{array}{l}\text { Unknown } \\
\text { leaf/stem }\end{array}$ & $1.6 \pm 1.6$ & $0.0 \pm 0.0$ & $0.0 \pm 0.0$ & $0.7 \pm 0.5$ & $0.0 \pm 0.0$ & $0.0 \pm 0.0$ & $32.0 \pm 32.0$ & $0.0 \pm 0.0$ & $0.0 \pm 0.0$ & $0.0 \pm 0.0$ \\
\hline $\begin{array}{l}\text { Unknown } \\
\text { nut/seed }\end{array}$ & $0.0 \pm 0.0$ & $0.6 \pm 0.6$ & $0.0 \pm 0.0$ & $1.5 \pm 1.5$ & $0.0 \pm 0.0$ & $0.6 \pm 0.4$ & $0.0 \pm 0.0$ & $0.0 \pm 0.0$ & $3.1 \pm 2.2$ & $0.0 \pm 0.0$ \\
\hline Unknown shrub & $0.0 \pm 0.0$ & $3.6 \pm 0.9$ & $3.1 \pm 2.0$ & $3.1 \pm 0.7$ & $0.0 \pm 0.0$ & $2.5 \pm 0.9$ & $0.0 \pm 0.0$ & $0.9 \pm 0.9$ & $1.1 \pm 1.1$ & $0.9 \pm 0.9$ \\
\hline \multicolumn{11}{|l|}{ Mosses } \\
\hline Unknown moss & $0.0 \pm 0.0$ & $0.0 \pm 0.0$ & $0.0 \pm 0.0$ & $0.0 \pm 0.0$ & $0.0 \pm 0.0$ & $0.0 \pm 0.0$ & $0.0 \pm 0.0$ & $1.3 \pm 1.3$ & $4.8 \pm 4.8$ & $2.2 \pm 2.2$ \\
\hline \multicolumn{11}{|l|}{ Lichen } \\
\hline Unknown lichen & $0.0 \pm 0.0$ & $0.0 \pm 0.0$ & $0.0 \pm 0.0$ & $0.0 \pm 0.0$ & $0.0 \pm 0.0$ & $0.0 \pm 0.0$ & $2.2 \pm 2.2$ & $0.0 \pm 0.0$ & $0.3 \pm 0.3$ & $0.3 \pm 0.3$ \\
\hline
\end{tabular}


APPENDIX D

FOOD ITEMS THAT COMPOSED > 2\% OF THE TOTAL DIET OF MALE AND FEMALE ALLEGHENY WOODRATS IN ANY SEASON FROM NOVEMBER 1997 - DECEMBER 1998 IN THE ALLEGHENY PLATEAU PHYSIOGRAPHIC PROVINCE OF WEST VIRGINIA 
Appendix D. Plants found in the diets of male and female Allegheny woodrats in the Allegheny Plateau Physiographic Province in West Virginia. Expressed as percent of the total diet \pm (SE). Taxonomy of the vascular plants follows Strausbaugh and Core (1977) and fungi following Lincoff and Knopf (1988).

\begin{tabular}{|c|c|c|c|c|c|c|c|c|c|c|}
\hline \multirow[t]{2}{*}{ Species } & \multicolumn{2}{|c|}{ Fall 1997} & \multicolumn{2}{|c|}{ Winter 1998} & \multicolumn{2}{|c|}{$\underline{\text { Spring } 1998}$} & \multicolumn{2}{|c|}{$\underline{\text { Summer } 1998}$} & \multicolumn{2}{|c|}{$\underline{\text { Fall } 1998}$} \\
\hline & $\begin{array}{l}\text { Male } \\
(n=8)\end{array}$ & $\begin{array}{c}\text { Female } \\
(n=7)\end{array}$ & $\begin{array}{l}\text { Male } \\
(n=3)\end{array}$ & $\begin{array}{c}\text { Female } \\
(n=9)\end{array}$ & $\begin{array}{l}\text { Male } \\
(n=5)\end{array}$ & $\begin{array}{c}\text { Female } \\
(n=8)\end{array}$ & $\begin{array}{l}\text { Male } \\
(n=6)\end{array}$ & $\begin{array}{c}\text { Female } \\
(n=7)\end{array}$ & $\begin{array}{l}\text { Male } \\
(n=6)\end{array}$ & $\begin{array}{c}\text { Female } \\
(n=9)\end{array}$ \\
\hline \multicolumn{11}{|l|}{ FUNGI } \\
\hline Unknown fungi & $20.6 \pm 5.4$ & $15.2 \pm 4.1$ & $1.4 \pm 0.8$ & $2.0 \pm 1.1$ & $6.9 \pm 2.4$ & $8.3 \pm 3.9$ & $27.9 \pm 8.1$ & $8.1 \pm 3.7$ & $13.7 \pm 8.2$ & $5.0 \pm 2.7$ \\
\hline \multicolumn{11}{|l|}{ Gautieriaceae } \\
\hline $\begin{array}{l}\text { Gauteria } \\
\text { morchelliformis }\end{array}$ & $1.4 \pm 0.9$ & $8.7 \pm 8.7$ & $0.0 \pm 0.0$ & $0.0 \pm 0.0$ & $0.0 \pm 0.0$ & $0.0 \pm 0.0$ & $3.7 \pm 3.1$ & $0.0 \pm 0.0$ & $0.0 \pm 0.0$ & $0.0 \pm 0.0$ \\
\hline $\begin{array}{l}\text { Unknown Puffball } \\
\text { fungi }\end{array}$ & $7.9 \pm 7.9$ & $0.0 \pm 0.0$ & $0.0 \pm 0.0$ & $11.3 \pm 5.5$ & $0.0 \pm 0.0$ & $1.9 \pm 1.6$ & $0.0 \pm 0.0$ & $0.0 \pm 0.0$ & $0.0 \pm 0.0$ & $12.4 \pm 7.8$ \\
\hline \multicolumn{11}{|l|}{ Polyporaceae } \\
\hline Unknown polypore & $0.0 \pm 0.0$ & $0.6 \pm 0.6$ & $1.8 \pm 1.8$ & $0.0 \pm 0.0$ & $0.8 \pm 0.8$ & $0.8 \pm 0.8$ & $2.8 \pm 1.9$ & $0.0 \pm 0.0$ & $0.4 \pm 0.4$ & $0.6 \pm 0.6$ \\
\hline \multicolumn{11}{|l|}{ FERNS } \\
\hline \multicolumn{11}{|l|}{ Polypodiaceae } \\
\hline $\begin{array}{l}\text { Dryopteris } \\
\text { marginalis }\end{array}$ & $5.5 \pm 3.3$ & $12.8 \pm 8.8$ & $25.0 \pm 15.4$ & $4.6 \pm 2.6$ & $1.0 \pm 0.0$ & $1.4 \pm 0.8$ & $0.0 \pm 0.0$ & $0.3 \pm 0.3$ & $23.9 \pm 12.3$ & $7.3 \pm 5.2$ \\
\hline $\begin{array}{l}\text { Pteridium } \\
\text { aquilinum }\end{array}$ & $2.6 \pm 1.9$ & $0.5 \pm 0.5$ & $4.5 \pm 2.8$ & $0.0 \pm 0.0$ & $2.6 \pm 2.6$ & $0.0 \pm 0.0$ & $0.5 \pm 0.5$ & $0.0 \pm 0.0$ & $0.7 \pm 0.7$ & $1.0 \pm 0.6$ \\
\hline
\end{tabular}

\section{PLANTS}

Pinaceae 
Appendix D. Continued.

\begin{tabular}{|c|c|c|c|c|c|c|c|c|c|c|}
\hline \multirow[t]{2}{*}{ Species } & \multicolumn{2}{|c|}{$\underline{\text { Fall } 1997}$} & \multicolumn{2}{|c|}{$\underline{\text { Winter } 1998}$} & \multicolumn{2}{|c|}{$\underline{\text { Spring } 1998}$} & \multicolumn{2}{|c|}{$\underline{\text { Summer } 1998}$} & \multicolumn{2}{|c|}{$\underline{\text { Fall } 1998}$} \\
\hline & $\begin{array}{l}\text { Male } \\
(n=8)\end{array}$ & $\begin{array}{c}\text { Female } \\
(n=7)\end{array}$ & $\begin{array}{l}\text { Male } \\
(n=3)\end{array}$ & $\begin{array}{c}\text { Female } \\
(n=9)\end{array}$ & $\begin{array}{l}\text { Male } \\
(n=5)\end{array}$ & $\begin{array}{c}\text { Female } \\
(n=8)\end{array}$ & $\begin{array}{l}\text { Male } \\
(n=6)\end{array}$ & $\begin{array}{c}\text { Female } \\
(n=7)\end{array}$ & $\begin{array}{l}\text { Male } \\
(n=6)\end{array}$ & $\begin{array}{c}\text { Female } \\
(n=9)\end{array}$ \\
\hline $\begin{array}{l}\text { Tsuga canadensis } \\
\text { needles }\end{array}$ & $0.0 \pm 0.0$ & $1.9 \pm 0.9$ & $20.3 \pm 18.4$ & $7.5 \pm 6.7$ & $0.0 \pm 0.0$ & $1.0 \pm 1.0$ & $0.0 \pm 0.0$ & $1.3 \pm 1.0$ & $0.0 \pm 0.0$ & $0.0 \pm 0.0$ \\
\hline \multicolumn{11}{|l|}{ Cyperaceae } \\
\hline Carex spp. & $7.7 \pm 7.7$ & $0.0 \pm 0.0$ & $0.0 \pm 0.0$ & $0.0 \pm 0.0$ & $0.2 \pm 0.2$ & $0.0 \pm 0.0$ & $4.1 \pm 4.1$ & $0.6 \pm 0.6$ & $0.0 \pm 0.0$ & $0.0 \pm 0.0$ \\
\hline \multicolumn{11}{|l|}{ Liliaceae } \\
\hline $\begin{array}{l}\text { Smilax spp. } \\
\text { fruit/seed }\end{array}$ & $4.9 \pm 2.3$ & $11.8 \pm 5.3$ & $19.0 \pm 19.0$ & $1.9 \pm 1.9$ & $10.3 \pm 10.3$ & $4.1 \pm 1.8$ & $0.7 \pm 0.7$ & $0.5 \pm 0.5$ & $0.2 \pm 0.2$ & $0.8 \pm 0.8$ \\
\hline S. spp. leaf/stem & $0.0 \pm 0.0$ & $1.1 \pm 0.8$ & $1.6 \pm 1.6$ & $0.0 \pm 0.0$ & $0.0 \pm 0.0$ & $3.2 \pm 2.2$ & $0.0 \pm 0.0$ & $0.0 \pm 0.0$ & $0.8 \pm 0.8$ & $0.0 \pm 0.0$ \\
\hline \multicolumn{11}{|l|}{ Juglandaceae } \\
\hline J. nigra nut & $6.5 \pm 6.5$ & $0.0 \pm 0.0$ & $0.0 \pm 0.0$ & $0.0 \pm 0.0$ & $0.3 \pm 0.3$ & $0.0 \pm 0.0$ & $0.0 \pm 0.0$ & $0.0 \pm 0.0$ & $0.0 \pm 0.0$ & $0.0 \pm 0.0$ \\
\hline Carya spp. leaf & $0.0 \pm 0.0$ & $0.1 \pm 0.1$ & $0.0 \pm 0.0$ & $0.0 \pm 0.0$ & $0.0 \pm 0.0$ & $0.0 \pm 0.0$ & $0.0 \pm 0.0$ & $0.0 \pm 0.0$ & $0.0 \pm 0.0$ & $0.0 \pm 0.0$ \\
\hline C. spp. nut & $4.7 \pm 2.5$ & $1.0 \pm 0.5$ & $0.0 \pm 0.0$ & $0.0 \pm 0.0$ & $0.5 \pm 0.5$ & $0.0 \pm 0.0$ & $0.1 \pm 0.1$ & $0.0 \pm 0.0$ & $0.0 \pm 0.0$ & $1.0 \pm 0.6$ \\
\hline \multicolumn{11}{|l|}{ Corylaceae } \\
\hline Ostrya/Fagus leaf ${ }^{1}$ & $0.0 \pm 0.0$ & $0.0 \pm 0.0$ & $0.0 \pm 0.0$ & $0.0 \pm 0.0$ & $3.9 \pm 3.1$ & $1.3 \pm 0.9$ & $0.0 \pm 0.0$ & $0.0 \pm 0.0$ & $0.0 \pm 0.0$ & $0.0 \pm 0.0$ \\
\hline$B$. spp leaf/stem & $0.0 \pm 0.0$ & $1.3 \pm 1.3$ & $0.0 \pm 0.0$ & $0.5 \pm 0.5$ & $1.4 \pm 1.4$ & $4.8 \pm 2.4$ & $0.5 \pm 0.5$ & $7.9 \pm 6.9$ & $1.8 \pm 1.8$ & $0.5 \pm 0.5$ \\
\hline Betula/Fagus bud & $0.0 \pm 0.0$ & $0.0 \pm 0.0$ & $0.0 \pm 0.0$ & $0.0 \pm 0.0$ & $0.0 \pm 0.0$ & $0.0 \pm 0.0$ & $0.0 \pm 0.0$ & $0.0 \pm 0.0$ & $0.0 \pm 0.0$ & $0.0 \pm 0.0$ \\
\hline $\begin{array}{l}\text { Alnus serrulata } \\
\text { leaf/stem }\end{array}$ & $0.0 \pm 0.0$ & $0.3 \pm 0.3$ & $0.0 \pm 0.0$ & $0.0 \pm 0.0$ & $3.6 \pm 3.6$ & $2.4 \pm 1.2$ & $0.3 \pm 0.3$ & $1.2 \pm 0.8$ & $0.0 \pm 0.0$ & $0.0 \pm 0.0$ \\
\hline
\end{tabular}

${ }^{1}$ Genera were pooled due to difficulty in distinguishing between similar cell structures. 


\begin{tabular}{|c|c|c|c|c|c|c|c|c|c|c|}
\hline \multirow[t]{2}{*}{ Species } & \multicolumn{2}{|c|}{$\underline{\text { Fall } 1997}$} & \multicolumn{2}{|c|}{$\underline{\text { Winter } 1998}$} & \multicolumn{2}{|c|}{$\underline{\text { Spring } 1998}$} & \multicolumn{2}{|c|}{$\underline{\text { Summer } 1998}$} & \multicolumn{2}{|c|}{$\underline{\text { Fall } 1998}$} \\
\hline & $\begin{array}{l}\text { Male } \\
(n=8)\end{array}$ & $\begin{array}{c}\text { Female } \\
(n=7)\end{array}$ & $\begin{array}{l}\text { Male } \\
(n=3)\end{array}$ & $\begin{array}{c}\text { Female } \\
(n=9)\end{array}$ & $\begin{array}{l}\text { Male } \\
(n=5)\end{array}$ & $\begin{array}{c}\text { Female } \\
(n=8)\end{array}$ & $\begin{array}{l}\text { Male } \\
(n=6)\end{array}$ & $\begin{array}{c}\text { Female } \\
(n=7)\end{array}$ & $\begin{array}{l}\text { Male } \\
(n=6)\end{array}$ & $\begin{array}{c}\text { Female } \\
(n=9)\end{array}$ \\
\hline \multicolumn{11}{|l|}{ Fagaceae } \\
\hline Fagus/Ostrya leaf & $0.0 \pm 0.0$ & $0.0 \pm 0.0$ & $0.0 \pm 0.0$ & $0.0 \pm 0.0$ & $3.9 \pm 3.1$ & $1.3 \pm 0.9$ & $0.0 \pm 0.0$ & $0.0 \pm 0.0$ & $0.0 \pm 0.0$ & $0.0 \pm 0.0$ \\
\hline Fagus/Betula bud & $0.0 \pm 0.0$ & $0.0 \pm 0.0$ & $0.0 \pm 0.0$ & $0.0 \pm 0.0$ & $0.0 \pm 0.0$ & $0.0 \pm 0.0$ & $0.0 \pm 0.0$ & $0.0 \pm 0.0$ & $0.0 \pm 0.0$ & $0.0 \pm 0.0$ \\
\hline $\begin{array}{l}\text { Quercus spp. } \\
\text { acorn }\end{array}$ & $3.2 \pm 2.0$ & $0.9 \pm 0.9$ & $1.3 \pm 1.3$ & $2.5 \pm 1.6$ & $1.6 \pm 1.6$ & $0.0 \pm 0.0$ & $2.0 \pm 2.0$ & $14.3 \pm 12.0$ & $24.7 \pm 13.0$ & $24.3 \pm 9.7$ \\
\hline$Q$. spp. leaf/stem & $0.0 \pm 0.0$ & $0.0 \pm 0.0$ & $0.0 \pm 0.0$ & $0.4 \pm 0.4$ & $1.6 \pm 1.6$ & $0.0 \pm 0.0$ & $0.0 \pm 0.0$ & $0.9 \pm 0.9$ & $0.0 \pm 0.0$ & $0.0 \pm 0.0$ \\
\hline $\begin{array}{l}Q . \text { velutinal } \\
\text { coccinea leaf }\end{array}$ & $0.0 \pm 0.0$ & $0.0 \pm 0.0$ & $0.0 \pm 0.0$ & $0.0 \pm 0.0$ & $0.3 \pm 0.3$ & $0.7 \pm 0.4$ & $0.0 \pm 0.0$ & $0.6 \pm 0.5$ & $0.4 \pm 0.4$ & $0.0 \pm 0.0$ \\
\hline \multicolumn{11}{|l|}{ Magnoliaceae } \\
\hline $\begin{array}{l}\text { Magnolia spp. } \\
\text { seed/cone }\end{array}$ & $1.4 \pm 0.8$ & $1.8 \pm 0.9$ & $0.9 \pm 0.9$ & $0.0 \pm 0.0$ & $3.2 \pm 2.1$ & $2.0 \pm 1.0$ & $0.0 \pm 0.0$ & $0.0 \pm 0.0$ & $1.9 \pm 1.0$ & $5.0 \pm 3.3$ \\
\hline$M$. spp. leaf & $0.0 \pm 0.0$ & $0.0 \pm 0.0$ & $0.0 \pm 0.0$ & $0.0 \pm 0.0$ & $0.0 \pm 0.0$ & $0.0 \pm 0.0$ & $0.0 \pm 0.0$ & $0.0 \pm 0.0$ & $1.8 \pm 1.8$ & $0.7 \pm 0.7$ \\
\hline \multicolumn{11}{|l|}{ Rosaceae } \\
\hline $\begin{array}{l}\text { Rubus spp. } \\
\text { fruit/seed }\end{array}$ & $6.9 \pm 6.9$ & $0.8 \pm 0.8$ & $0.0 \pm 0.0$ & $0.5 \pm 0.5$ & $0.0 \pm 0.0$ & $0.0 \pm 0.0$ & $0.5 \pm 0.5$ & $0.2 \pm 0.2$ & $4.2 \pm 2.9$ & $0.6 \pm 0.6$ \\
\hline$R$. spp. leaf/stem & $2.5 \pm 1.2$ & $5.3 \pm 2.0$ & $4.8 \pm 4.8$ & $5.1 \pm 1.8$ & $2.5 \pm 2.2$ & $5.1 \pm 1.6$ & $1.5 \pm 1.5$ & $0.3 \pm 0.3$ & $2.1 \pm 1.5$ & $2.5 \pm 1.2$ \\
\hline $\begin{array}{l}\text { Rosa spp. } \\
\text { leaf/stem }\end{array}$ & $0.0 \pm 0.0$ & $0.5 \pm 0.5$ & $0.0 \pm 0.0$ & $0.0 \pm 0.0$ & $0.0 \pm 0.0$ & $0.0 \pm 0.0$ & $0.0 \pm 0.0$ & $0.0 \pm 0.0$ & $0.0 \pm 0.0$ & $0.0 \pm 0.0$ \\
\hline$R$. spp. seed & $0.0 \pm 0.0$ & $0.4 \pm 0.4$ & $0.0 \pm 0.0$ & $2.0 \pm 1.4$ & $3.0 \pm 2.0$ & $0.7 \pm 0.7$ & $0.0 \pm 0.0$ & $0.0 \pm 0.0$ & $0.0 \pm 0.0$ & $2.0 \pm 2.0$ \\
\hline $\begin{array}{l}\text { Crataegus spp. } \\
\text { leaf }\end{array}$ & $1.1 \pm 0.7$ & $3.9 \pm 1.3$ & $0.0 \pm 0.0$ & $0.8 \pm 0.8$ & $0.0 \pm 0.0$ & $0.3 \pm 0.3$ & $0.7 \pm 0.7$ & $0.0 \pm 0.0$ & $0.0 \pm 0.0$ & $1.1 \pm 0.7$ \\
\hline
\end{tabular}




\begin{tabular}{|c|c|c|c|c|c|c|c|c|c|c|}
\hline \multirow[t]{2}{*}{ Species } & \multicolumn{2}{|c|}{$\underline{\text { Fall } 1997}$} & \multicolumn{2}{|c|}{$\underline{\text { Winter } 1998}$} & \multicolumn{2}{|c|}{ Spring 1998} & \multicolumn{2}{|c|}{$\underline{\text { Summer } 1998}$} & \multicolumn{2}{|c|}{$\underline{\text { Fall } 1998}$} \\
\hline & $\begin{array}{l}\text { Male } \\
(n=8)\end{array}$ & $\begin{array}{c}\text { Female } \\
(n=7)\end{array}$ & $\begin{array}{l}\text { Male } \\
(n=3)\end{array}$ & $\begin{array}{c}\text { Female } \\
(n=9)\end{array}$ & $\begin{array}{l}\text { Male } \\
(n=5)\end{array}$ & $\begin{array}{c}\text { Female } \\
(n=8)\end{array}$ & $\begin{array}{l}\text { Male } \\
(n=6)\end{array}$ & $\begin{array}{c}\text { Female } \\
(n=7)\end{array}$ & $\begin{array}{l}\text { Male } \\
(n=6)\end{array}$ & $\begin{array}{c}\text { Female } \\
(n=9)\end{array}$ \\
\hline$P$. spp. leaf/stem & $0.0 \pm 0.0$ & $0.0 \pm 0.0$ & $0.0 \pm 0.0$ & $1.2 \pm 1.0$ & $4.0 \pm 2.7$ & $1.0 \pm 0.7$ & $0.0 \pm 0.0$ & $1.9 \pm 1.3$ & $0.0 \pm 0.0$ & $0.6 \pm 0.6$ \\
\hline \multicolumn{11}{|l|}{ Fabaceae } \\
\hline $\begin{array}{l}\text { Cercis canadensis } \\
\text { leaf }\end{array}$ & $2.0 \pm 1.6$ & $0.6 \pm 0.6$ & $0.0 \pm 0.0$ & $0.5 \pm 0.5$ & $0.3 \pm 0.3$ & $1.4 \pm 1.0$ & $0.0 \pm 0.0$ & $0.4 \pm 0.4$ & $0.0 \pm 0.0$ & $1.1 \pm 1.1$ \\
\hline C. canadensis pod & $0.0 \pm 0.0$ & $0.0 \pm 0.0$ & $0.0 \pm 0.0$ & $0.0 \pm 0.0$ & $1.3 \pm 1.3$ & $0.3 \pm 0.3$ & $1.6 \pm 1.6$ & $1.3 \pm 1.3$ & $0.5 \pm 0.5$ & $0.0 \pm 0.0$ \\
\hline \multicolumn{11}{|l|}{ Oxalidaceae } \\
\hline Oxalis spp. & $0.0 \pm 0.0$ & $0.0 \pm 0.0$ & $0.0 \pm 0.0$ & $0.0 \pm 0.0$ & $0.0 \pm 0.0$ & $0.0 \pm 0.0$ & $0.0 \pm 0.0$ & $0.0 \pm 0.0$ & $0.0 \pm 0.0$ & $0.0 \pm 0.0$ \\
\hline \multicolumn{11}{|l|}{ Aquifoliaceae } \\
\hline Ilex spp. fruit & $0.0 \pm 0.0$ & $0.0 \pm 0.0$ & $0.0 \pm 0.0$ & $0.0 \pm 0.0$ & $0.0 \pm 0.0$ & $0.0 \pm 0.0$ & $0.0 \pm 0.0$ & $0.0 \pm 0.0$ & $0.0 \pm 0.0$ & $0.0 \pm 0.0$ \\
\hline $\begin{array}{l}\text { Ilex/Vaccinium } \\
\text { fruit/seed }\end{array}$ & $2.4 \pm 1.6$ & $4.2 \pm 1.6$ & $6.3 \pm 5.4$ & $5.9 \pm 2.5$ & $12.9 \pm 5.4$ & $8.1 \pm 3.2$ & $12.1 \pm 9.4$ & $16.4 \pm 11.5$ & $2.2 \pm 0.9$ & $4.9 \pm 2.7$ \\
\hline \multicolumn{11}{|l|}{ Araliaceae } \\
\hline Aralia spinosa & $0.0 \pm 0.0$ & $1.3 \pm 1.3$ & $2.7 \pm 2.7$ & $9.8 \pm 3.5$ & $0.4 \pm 0.4$ & $7.8 \pm 6.7$ & $0.0 \pm 0.0$ & $0.0 \pm 0.0$ & $0.9 \pm 0.7$ & $0.4 \pm 0.4$ \\
\hline \multicolumn{11}{|l|}{ Elaeagnaceae } \\
\hline $\begin{array}{l}\text { Elaeagnus } \\
\text { umbellata leaf }\end{array}$ & $0.0 \pm 0.0$ & $0.0 \pm 0.0$ & $0.0 \pm 0.0$ & $0.0 \pm 0.0$ & $0.0 \pm 0.0$ & $0.0 \pm 0.0$ & $0.0 \pm 0.0$ & $0.0 \pm 0.0$ & $0.0 \pm 0.0$ & $0.0 \pm 0.0$ \\
\hline E. umbellata seed & $0.7 \pm 0.5$ & $0.0 \pm 0.0$ & $0.0 \pm 0.0$ & $1.2 \pm 1.2$ & $0.0 \pm 0.0$ & $0.4 \pm 0.4$ & $0.0 \pm 0.0$ & $0.0 \pm 0.0$ & $0.6 \pm 0.6$ & $0.0 \pm 0.0$ \\
\hline \multicolumn{11}{|l|}{ Cornaceae } \\
\hline Cornus spp. leaf & $0.0 \pm 0.0$ & $0.0 \pm 0.0$ & $0.0 \pm 0.0$ & $04 \pm 0.4$ & $0.0 \pm 0.0$ & $0.8 \pm 0.8$ & $0.0 \pm 0.0$ & $1.2 \pm 1.2$ & $0.0 \pm 0.0$ & $0.0 \pm 0.0$ \\
\hline
\end{tabular}




\begin{tabular}{|c|c|c|c|c|c|c|c|c|c|c|}
\hline \multirow[t]{2}{*}{ Species } & \multicolumn{2}{|c|}{$\underline{\text { Fall } 1997}$} & \multicolumn{2}{|c|}{$\underline{\text { Winter } 1998}$} & \multicolumn{2}{|c|}{ Spring 1998} & \multicolumn{2}{|c|}{$\underline{\text { Summer } 1998}$} & \multicolumn{2}{|c|}{$\underline{\text { Fall } 1998}$} \\
\hline & $\begin{array}{l}\text { Male } \\
(n=8)\end{array}$ & $\begin{array}{c}\text { Female } \\
(n=7)\end{array}$ & $\begin{array}{l}\text { Male } \\
(n=3)\end{array}$ & $\begin{array}{l}\text { Female } \\
(n=9)\end{array}$ & $\begin{array}{l}\text { Male } \\
(n=5)\end{array}$ & $\begin{array}{c}\text { Female } \\
(n=8)\end{array}$ & $\begin{array}{l}\text { Male } \\
(n=6)\end{array}$ & $\begin{array}{c}\text { Female } \\
(n=7)\end{array}$ & $\begin{array}{l}\text { Male } \\
(n=6)\end{array}$ & $\begin{array}{c}\text { Female } \\
(n=9)\end{array}$ \\
\hline Cornus/Ilex stem & $0.0 \pm 0.0$ & $0.0 \pm 0.0$ & $0.9 \pm 0.9$ & $3.6 \pm 2.3$ & $4.9 \pm 3.2$ & $0.9 \pm 0.9$ & $0.0 \pm 00$ & $0.2 \pm 0.2$ & $0.7 \pm 0.7$ & $0.0 \pm 0.0$ \\
\hline \multicolumn{11}{|l|}{ Ericaceae } \\
\hline $\begin{array}{l}\text { Rhododendron } \\
\text { spp. leaf/stem }\end{array}$ & $0.0 \pm 0.0$ & $0.9 \pm 0.7$ & $0.0 \pm 0.0$ & $8.2 \pm 5.5$ & $2.6 \pm 1.6$ & $7.9 \pm 5.1$ & $2.3 \pm 1.5$ & $0.4 \pm 0.4$ & $0.3 \pm 0.3$ & $5.5 \pm 3.4$ \\
\hline $\begin{array}{l}\text { Vaccinium spp. } \\
\text { fruit/seed }\end{array}$ & $0.0 \pm 0.0$ & $0.0 \pm 0.0$ & $0.0 \pm 0.0$ & $0.2 \pm 0.2$ & $0.0 \pm 0.0$ & $0.0 \pm 0.0$ & $0.0 \pm 0.0$ & $0.0 \pm 0.0$ & $0.0 \pm 0.0$ & $0.0 \pm 0.0$ \\
\hline$V$. spp. leaf/stem & $0.4 \pm 0.4$ & $3.2 \pm 2.2$ & $3.6 \pm 1.9$ & $10.2 \pm 6.4$ & $6.9 \pm 3.1$ & $4.6 \pm 1.9$ & $0.8 \pm 0.8$ & $0.0 \pm 0.0$ & $5.1 \pm 2.8$ & $6.9 \pm 3.4$ \\
\hline $\begin{array}{l}\text { Vaccinium/ } \\
\text { Rhododendron } \\
\text { stem }\end{array}$ & $0.0 \pm 0.0$ & $0.0 \pm 0.0$ & $0.0 \pm 0.0$ & $1.2 \pm 1.2$ & $0.0 \pm 0.0$ & $1.2 \pm 1.2$ & $0.0 \pm 0.0$ & $0.0 \pm 0.0$ & $0.0 \pm 0.0$ & $0.0 \pm 0.0$ \\
\hline $\begin{array}{l}\text { Vaccinium/Ilex } \\
\text { fruit/seed }\end{array}$ & $2.4 \pm 1.6$ & $4.2 \pm 1.6$ & $6.3 \pm 5.4$ & $9.9 \pm 3.5$ & $12.9 \pm 5.4$ & $8.1 \pm 3.2$ & $12.1 \pm 9.4$ & $16.4 \pm 11.5$ & $2.2 \pm 0.9$ & $4.9 \pm 2.7$ \\
\hline \multicolumn{11}{|l|}{ Caprifoliaceae } \\
\hline $\begin{array}{l}\text { Viburnum spp. } \\
\text { fruit }\end{array}$ & $2.2 \pm 1.1$ & $0.7 \pm 0.5$ & $0.0 \pm 0.0$ & $3.0 \pm 1.6$ & $3.6 \pm 2.2$ & $3.5 \pm 1.9$ & $6.5 \pm 5.7$ & $5.2 \pm 3.7$ & $0.0 \pm 0.0$ & $1.0 \pm 0.7$ \\
\hline $\begin{array}{l}\text { Sambucus nigra } \\
\text { leaf }\end{array}$ & $0.8 \pm 0.8$ & $0.7 \pm 0.7$ & $0.0 \pm 0.0$ & $4.4 \pm 1.5$ & $0.0 \pm 0.0$ & $4.0 \pm 3.0$ & $0.0 \pm 0.0$ & $0.0 \pm 0.0$ & $0.9 \pm 0.9$ & $0.0 \pm 0.0$ \\
\hline \multicolumn{11}{|l|}{ Asteraceae } \\
\hline Aster spp. & $0.0 \pm 0.0$ & $0.0 \pm 0.0$ & $0.0 \pm 0.0$ & $0.1 \pm 0.1$ & $0.3 \pm 0.3$ & $0.4 \pm 0.4$ & $0.4 \pm 0.4$ & $0.0 \pm 0.0$ & $0.0 \pm 0.0$ & $0.0 \pm 0.0$ \\
\hline $\begin{array}{l}\text { Prenanthes spp. } \\
\text { Flower/seed }\end{array}$ & $0.0 \pm 0.0$ & $0.0 \pm 0.0$ & $0.0 \pm 0.0$ & $0.0 \pm 0.0$ & $0.0 \pm 0.0$ & $0.0 \pm 0.0$ & $0.0 \pm 0.0$ & $0.0 \pm 0.0$ & $0.0 \pm 0.0$ & $0.0 \pm 0.0$ \\
\hline
\end{tabular}


Appendix D. Continued.

\begin{tabular}{|c|c|c|c|c|c|c|c|c|c|c|}
\hline \multirow[t]{2}{*}{ Species } & \multicolumn{2}{|c|}{$\underline{\text { Fall } 1997}$} & \multicolumn{2}{|c|}{$\underline{\text { Winter } 1998}$} & \multicolumn{2}{|c|}{ Spring 1998} & \multicolumn{2}{|c|}{$\underline{\text { Summer } 1998}$} & \multicolumn{2}{|c|}{$\underline{\text { Fall } 1998}$} \\
\hline & $\begin{array}{l}\text { Male } \\
(n=8)\end{array}$ & $\begin{array}{c}\text { Female } \\
(n=7)\end{array}$ & $\begin{array}{l}\text { Male } \\
(n=3)\end{array}$ & $\begin{array}{c}\text { Female } \\
(n=9)\end{array}$ & $\begin{array}{l}\text { Male } \\
(n=5)\end{array}$ & $\begin{array}{c}\text { Female } \\
(n=8)\end{array}$ & $\begin{array}{l}\text { Male } \\
(n=6)\end{array}$ & $\begin{array}{c}\text { Female } \\
(n=7)\end{array}$ & $\begin{array}{l}\text { Male } \\
(n=6)\end{array}$ & $\begin{array}{c}\text { Female } \\
(n=9)\end{array}$ \\
\hline \multicolumn{11}{|l|}{ Miscellaneous plants } \\
\hline Unknown flower & $0.0 \pm 0.0$ & $0.0 \pm 0.0$ & $0.0 \pm 0.0$ & $0.0 \pm 0.0$ & $0.0 \pm 0.0$ & $0.0 \pm 0.0$ & $0.0 \pm 0.0$ & $0.7 \pm 0.7$ & $0.0 \pm 0.0$ & $0.0 \pm 0.0$ \\
\hline Unknown leaf/stem & $0.0 \pm 0.0$ & $0.0 \pm 0.0$ & $0.0 \pm 0.0$ & $0.0 \pm 0.0$ & $4.1 \pm 2.2$ & $1.1 \pm 0.8$ & $0.3 \pm 0.3$ & $0.7 \pm 0.7$ & $0.5 \pm 0.5$ & $0.0 \pm 0.0$ \\
\hline Unknown nut/seed & $1.3 \pm 0.6$ & $2.7 \pm 2.3$ & $0.0 \pm 0.0$ & $0.2 \pm 0.2$ & $1.4 \pm 1.4$ & $1.7 \pm 1.4$ & $0.0+0.0$ & $0.0 \pm 0.0$ & $0.0 \pm 0.0$ & $1.0 \pm 1.0$ \\
\hline Unknown shrub & $0.2 \pm 0.2$ & $1.0 \pm 0.7$ & $0.6 \pm 0.6$ & $2.7 \pm 1.0$ & $0.8 \pm 0.8$ & $2.0 \pm 0.8$ & $1.7 \pm 0.9$ & $0.0 \pm 0.0$ & $0.5 \pm 0.5$ & $1.3 \pm 0.7$ \\
\hline \multicolumn{11}{|l|}{ Mosses } \\
\hline Unknown moss & $0.0 \pm 0.0$ & $0.6 \pm 0.5$ & $0.0 \pm 0.0$ & $0.0 \pm 0.0$ & $1.1 \pm 0.8$ & $0.3 \pm 0.3$ & $0.0 \pm 0.0$ & $0.7 \pm 0.4$ & $0.3 \pm 0.3$ & $0.6 \pm 0.5$ \\
\hline
\end{tabular}




\section{VITA FOR NIKOLE L. CASTLEBERRY}

Nikole was born in Southern California on August 5, 1972 to Carlos van der Maath and Debby Lyon. She attended San Luis Obispo High School and graduated in 1990. She then briefly attended San Jose State University before transferring to the University of Georgia where she graduated with a Batchelors of Science in Forest Resources from the D. B. Warnell School of Forest Resources in 1996. She then worked for the University of Georgia Museum of Natural History until August 1997 when she began graduate school at West Virginia University.

Her research interests are small mammal and herptile ecology and management. Most of her research has focused on amphibians and small mammals such as mice, shrews, and bats within the southeastern United States. 